CENTRO UNIVERSITÁRIO FEI

MARCOS MANOEL LOPES JUNIOR

REGRAS PARA PROGRAMAÇÃO DA PRODUÇÃO EM SISTEMAS DE MANUFATURA COM PROCESSOS DE CURTA DURAÇÃO VISANDO EFICIÊNCIA ENERGÉTICA

São Bernardo do Campo 
MARCOS MANOEL LOPES JUNIOR

\section{REGRAS PARA PROGRAMAÇÃO DA PRODUÇÃO EM SISTEMAS DE MANUFATURA COM PROCESSOS DE CURTA DURAÇÃO VISANDO EFICIÊNCIA ENERGÉTICA}

Dissertação de Mestrado apresentada ao Centro Universitário FEI para obtenção do título de Mestre em Engenharia Mecânica. Orientado pelo Prof. Dr. Fábio Lima.

São Bernardo do Campo 
Manoel Lopes Junior, Marcos.

REGRAS PARA PROGRAMAÇÃO DA PRODUÇÃO EM

SISTEMAS DE MANUFATURA COM PROCESSOS DE CURTA

DURAÇÃO VISANDO EFICIÊNCIA ENERGÉTICA / Marcos Manoel

Lopes Junior. São Bernardo do Campo, 2018.

93 p. : il.

Dissertação - Centro Universitário FEI.

Orientador: Prof. Dr. Fábio Lima.

1. Eficiência Energética. 2. Indústria 4.0. 3. Simulação. 4. Manufatura Digital. I. Lima, Fábio, orient. II. Título.

Elaborada pelo sistema de geração automática de ficha catalográfica da FEI com os dados fornecidos pelo(a) autor(a). 
Aluno: Marcos Manoel Lopes Junior

Título do Trabalho: Regras para programação da produção em sistemas de manufatura com processos de curta duração visando eficiência energética.

Área de Concentração: Produção

Orientador: Prof. Dr. Fábio Lima

Data da realização da defesa: 26/10/2018

\section{MEMBROS DA BANCA EXAMINADORA}

Prof. Dr. Fábio Lima

Prof. Dr. Daniel de Oliveira Mota

Prof. Dr. Alexandre Augusto Massote
Ass. :

Ass. :

Ass. :

A Banca Julgadora acima-assinada atribuiu ao aluno o seguinte resultado:

APROVADO \ REPROVADO

\section{VERSÃO FINAL DA DISSERTAČ̃̃O}

APROVO A VERSÃO FINAL DA DISSERTAÇÃO EM QUE FORAM INCLUÍDAS AS RECOMENDAÇÕES DA BANCA EXAMINADORA
Aprovação do Coordenador do Programa de Pós-graduação

Prof. Dr. Rodrigo Magnabosco 
Dedico este trabalho aos meus pais, irmã e especialmente a minha esposa, que com muita paciência e compreensão suportaram minha ausência e entenderam a grande importância deste trabalho para mim. Sem o apoio e suporte de vocês, não seria possível realizar este grande sonho. 


\section{AGRADECIMENTOS}

Aos meus pais Marcos e Solange, a minha irmã Maraísa e minha esposa Camila que, com muito carinho e apoio, não mediram esforços durante esta jornada e que em muitos momentos souberam me orientar para para que eu chegasse até esta etapa de minha vida.

Agradeço a todos os professores que ministraram a parte curricular deste Mestrado, cujos ensinamentos me permitiram conduzir este trabalho e obter experiências muito significativas, especialmente ao meu orientador Prof. Dr. Fábio Lima. Obrigado, mestre, por exigir de mim muito mais do que eu imaginava ser capaz de fazer. Manifesto aqui minha gratidão eterna por compartilhar sua sabedoria, o seu tempo e sua experiência.

Ao Prof. Dr. Alexandre Augusto Massote e ao Prof. Dr. João Chang Junior, pelos comentários e valiosas contribuições realizadas a este trabalho durante a etapa de qualificação.

Aos amigos e colaboradores do Centro Universitário FEI, pela convivência e troca de experiências. 
"Os que se encantam com a prática sem a ciência são como os timoneiros que entram no navio sem timão nem bússola, nunca tendo certeza do seu destino". 


\section{RESUMO}

A eficiência energética é um tema discutido mundialmente dada sua relevância para as questões relacionadas à sustentabilidade e à sua participação no crescimento econômico de forma direta, uma vez que o consumo de energia elétrica, embora fomentado pelo consumidor da ponta, tem como maior consumidor unitário o setor industrial. Este fator, com consequências econômicas e ambientais, tem feito com que as indústrias busquem identificar melhorias que possam aumentar a eficiência energética, com o objetivo de reduzir seus custos operacionais e tornar os processos mais sustentáveis. Desta forma, este trabalho avalia o consumo de energia elétrica em um sistema de manufatura através da aplicação de modelos de simulação que utilizam os conceitos da manufatura digital e, a partir dos resultados, identifica os elementos que auxiliam nas tomadas de decisões e atuam como suporte para novos investimentos e projetos. Para realizar a avaliação, as análises e a identificação das oportunidades de melhoria, a metodologia utilizada contempla a construção de um modelo de simulação com diversos cenários, a partir de um simulador de eventos discretos pertencente a um pacote de software de manufatura digital. Os cenários foram construídos através de dados energéticos e de manufatura de um sistema de manufatura com processos de ciclos curtos. Este sistema de manufatura produz milhares de peças diariamente e não possui nenhuma regra de programação para controlar o consumo energético, desta forma, a simulação dos cenários tem como objetivo identificar os elementos que contribuem para melhorar a eficiência energética nos sistemas de manufatura com processos de ciclos curtos, bem como suas interações. Os resultados mostram que a utilização dos conceitos de manufatura digital voltada à simulação do consumo de energia permite não apenas a identificação de oportunidades de melhorias e racionalização dos recursos já existentes, como também a utilização dos indicadores como suporte para tomada de decisões no processo de desenvolvimento de novos projetos.

Palavras-chave: Eficiência Energética. Indústria 4.0. Simulação. Manufatura Digital. 


\begin{abstract}
Energy efficiency is a topic discussed worldwide given its relevance to issues related to sustainability and to its participation in economic growth in a direct way, since the consumption of electric energy, although encouraged by the final consumer, has as its main unitary consumer industrial sector. This factor, with economic and environmental consequences, has led industries to seek for identifying improvements that can increase energy efficiency, in order to reduce their operating costs and developing more sustainable processes. In this way, this work aims to evaluate the consumption of electric energy in a manufacturing system through the application of simulation models that use the concepts of digital manufacturing and, based on the results, identifies the elements that back the decision making up and act as support for new investments and projects. For the sake of carrying out the evaluation, analysis and identification of opportunities for improvements, the methodology used includes the construction of a simulation model with several scenarios, based on a discrete event simulator which belongs to a digital manufacturing software package. The scenarios were developed through energy and manufacturing data of a manufacturing system with short cycles processes, this manufacturing system produces thousands of pieces daily and has no programming rule to control the energy consumption, in this way, the simulation of the scenarios aims to identify the elements that contribute to improve the energy efficiency in manufacturing systems with short cycles processes as well as their interactions. The results have shown that the use of digital manufacturing concepts directed to the simulation of energy consumption not only allows the identification of opportunities for improvement and rationalization of existing resources through the application of concepts and methods, but also the use of indicators as support for decision-making in the process of developing new projects.
\end{abstract}

Keywords: Energy Efficiency. Industry 4.0. Simulation. Digital Manufacturing. 


\section{LISTA DE ILUSTRAÇÕES}

Figura 01 - Etapas de um modelo de simulação computacional

Quadro 01 - Metodologias de eficiência aplicáveis aos diferentes níveis dos sistemas de produção

Figura 02 - Paradigmas de simulação de energia elétrica em sistemas de manufatura ....

Figura 03 - Os quatro estágios da Revolução Industrial

Figura 04 - Modelo conceitual da Indústria 4.0

Figura 05 - Reduções potenciais durante paradas não planejadas nos sistemas de manufatura

Figura 06 - Estágios de desenvolvimento da Indústria 4.0

Figura 07 - Índice de maturidade da Indústria 4.0

Quadro 02 - Níveis de agregação de KPI voltados a eficiência energética

Quadro 03 - Estados de energia

Quadro 04 - Estados de manufatura 38

Figura 08 - Relação entre os estados de energia e os estados de manufatura 39

Figura 09 - Diagrama de energia 40

Quadro 05 - Fatores de análise de energia elétrica 41

Figura 10 - Composição de renováveis na matriz energética brasileira e mundo 42

Figura 11 - Percentual de geração de energia elétrica por renováveis 43

Figura 12 - Esquema comparativo de geração de eletricidade x consumo de eletricidade no

Brasil

Quadro 06 - Resumo das composições tarifárias 46

Quadro 07 - Sistema de bandeiras tarifárias

Figura 13 - Impacto do "realismo tarifário" do governo no custo de energia para a indústria

Quadro 08 - Custo mensal de energia da empresa em estudo

Figura 14 - Fluxo de processos do sistema de manufatura em estudo

Figura 15 - Layout da linha de produção do estudo

Quadro 09 - Descritivo dos cenários em estudo

Quadro 10 - Diagrama de processo e parâmetros de modelagem

Figura 16 - Ilustração do modelo de simulação do cenário A

Figura 17 - Gráfico de consumo de energia referente à simulação do cenário A

Figura 18 - Quantidade de unidades nos buffers durante a simulação do cenário A 
Figura 19 - Ilustração do modelo de simulação do cenário B

Figura 20 - Gráfico de consumo de energia referente à simulação do cenário B

Figura 21 - Quantidade de unidades nos buffers durante a simulação do cenário B

Figura 22 - Ilustração do modelo de simulação do cenário C

Figura 23 - Gráfico de consumo de energia referente à simulação do cenário $\mathrm{C}$

Figura 24 - Quantidade de unidades nos buffers durante a simulação do cenário C

Figura 25 - Quantidade de unidades nos sistemas de alimentação durante a simulação do

cenário $\mathrm{C}$

Figura 26 - Ilustração do modelo de simulação do cenário D 75

Figura 27 - Gráfico de consumo de energia referente à simulação do cenário D 76

Figura 28 - Quantidade de unidades nos buffers durante a simulação do cenário D 77

Figura 29 - Quantidade de unidades nos sistemas de alimentação durante a simulação do cenário D

Figura 30 - Gráfico de produção versus estados de máquina por cenário 80

Figura 31 - Gráfico de consumo de energia por estado de máquina em cada cenário 83

Figura 32 - Resultado das análises realizadas nos cenários avaliados 


\section{LISTA DE TABELAS}

Tabela 01 - Composição do custo médio da energia elétrica para a indústria no Brasil ... 48

Tabela 02 - Análise estatística dos dados básicos coletados para a estação M1 ............. 53

Tabela 03 - Parâmetros básicos de entrada para a simulação do modelo ......................... 54

Tabela 04 - Parâmetros básicos de entrada para a simulação de energia ......................... 55

Tabela 05 - Parâmetros básicos para a simulação do modelo referente ao cenário A ....... 57

Tabela 06 - Parâmetros básicos para a simulação de energia referente ao cenário A ....... 57

Tabela 07 - Parâmetros básicos para a simulação do modelo referente ao cenário B ....... 58

Tabela 08 - Parâmetros básicos para a simulação de energia referente ao cenário B ....... 58

Tabela 09 - Parâmetros básicos para a simulação do modelo referente ao cenário C ....... 59

Tabela 10 - Parâmetros básicos para a simulação de energia referente ao cenário C ....... 59

Tabela 11 - Parâmetros básicos para a simulação do modelo referente ao cenário D ....... 60

Tabela 12 - Parâmetros básicos para a simulação de energia referente ao cenário D ....... 60

Tabela 13 - Resultados de produtividade extraídos da simulação referente ao cenário A . 64

Tabela 14 - Consumo de energia em estado de máquina referente a simulação do

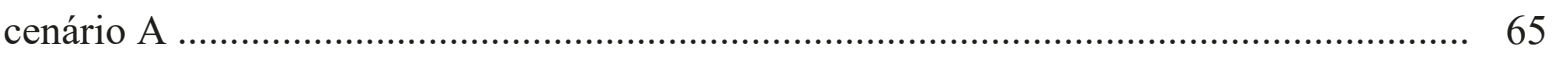

Tabela 15 - Resultados de produtividade extraídos da simulação referente ao cenário B . 67

Tabela 16 - Consumo de energia em estado de máquina referente a simulação do

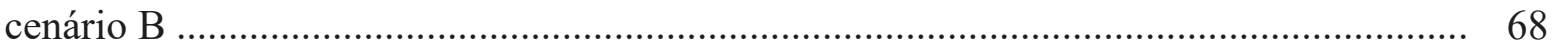

Tabela 17 - Resultados de produtividade extraídos da simulação referente ao cenário C . 71

Tabela 18 - Consumo de energia em estado de máquina referente a simulação do

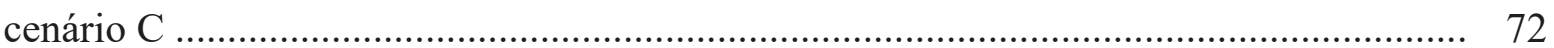

Tabela 19 - Parâmetros de paradas planejadas ........................................................... 74

Tabela 20 - Resultados de produtividade extraídos da simulação referente ao cenário D . 75

Tabela 21 - Consumo de energia em estado de máquina referente a simulação do

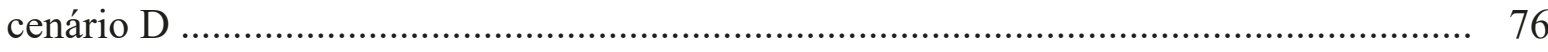

Tabela 22 - Unidades produzidas em cada cenário ...................................................... 78

Tabela 23 - Dados de consumo de energia e indicadores de eficiência energética ........... 82

Tabela 24 - Eficiência energética e avaliação financeira dos cenários ............................ 85 


\section{LISTA DE ABREVIATURAS E SIGLAS}

ACATECH Academia Alemã de Ciências e Engenharia

ANEEL Agência Nacional de Energia Elétrica

BRIC Agrupamento econômico composto por Brasil, Rússia, Índia e China.

CAD Desenho Assistido por Computador

CAE Engenharia Assistida por Computador

CAM Manufatura Assistida por Computador

CAT Teste Assistido por Computador

CEU Consumo de Energia Unitário

CNI Confederação Nacional da Indústria

CPS Sistemas Cyber-Físicos

DES Simulação de Eventos Discretos

EPE Empresa de Pesquisa Energética

ESO Oportunidade de Economia de Energia

EU União Europeia

e-KPI Indicador-chave de Desempenho Energético

FIRJAN Federação das Indústrias do Rio de Janeiro

GTD Geração, transmissão e distribuição

GWh Gigawatt-hora

ISO Organização Internacional para Padronização

KPI Indicador-chave de Desempenho

$\mathrm{kW} \quad$ Quilowatt

kWh Quilowatt-hora

LEI Lean Energy Indicator

MME Ministério de Minas e Energia

MWh Megawatt-hora

MTBF Tempo médio entre falhas

MTTR Tempo médio de reparo

ONS Operador Nacional do Sistema Elétrico

PLM Gerenciamento do Ciclo de Vida do Produto

SME Segmento de Pequenas Empresas

TI Tecnologia da Informação

TWh Terawatt-hora 


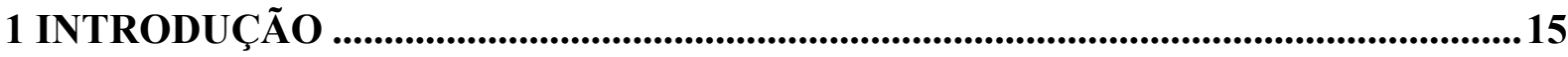

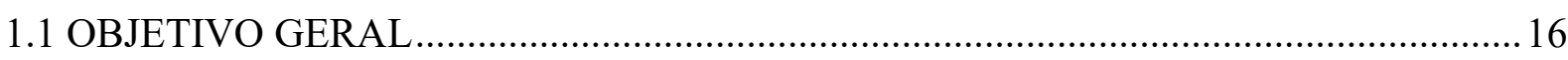

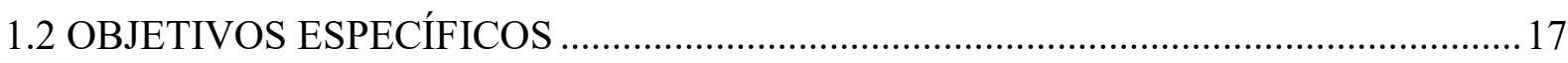

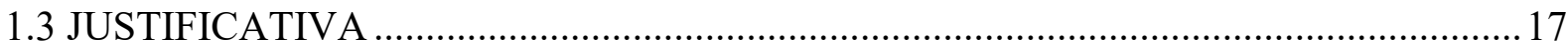

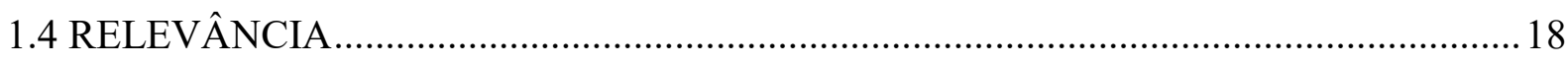

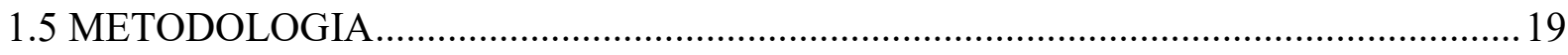

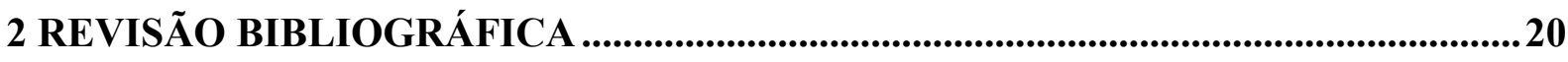

2.1 A ENERGIA EM SISTEMAS DE MANUFATURA E INICIATIVAS DE PESQUISAS

2.2.1 Métodos analíticos de identificação de oportunidade de economia de energia (ESO)

2.2.2 Simulação de eventos discretos (DES) .................................................................................26

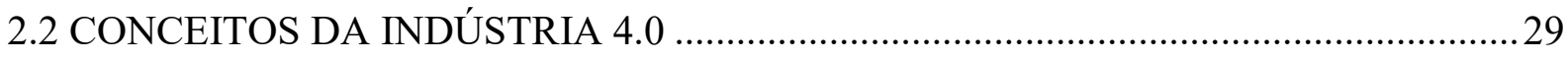

2.2.1 Manufatura Digital..........................................................................................................................34

2.3 INDICADORES DE DESEMPENHO (KPI) VOLTADOS À EFICIÊNCIA

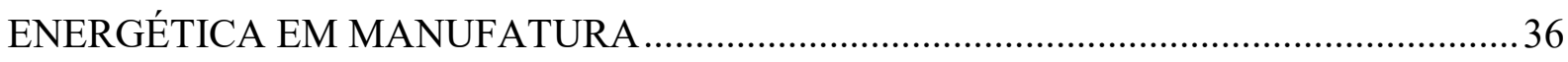

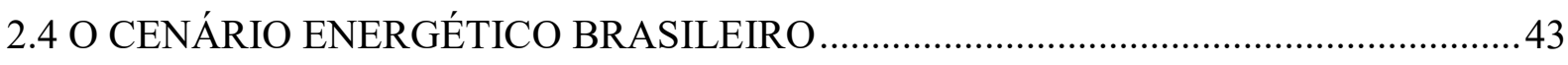

2.4.1 O sistema brasileiro de tarifação de energia .....................................................45

2.5 BARREIRAS PARA A APLICAÇÃO DOS CONCEITOS DE EFICIÊNCIA

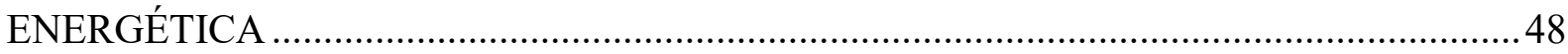

\section{DESCRIÇÃO DO SISTEMA DE MANUFATURA ABORDADO E}

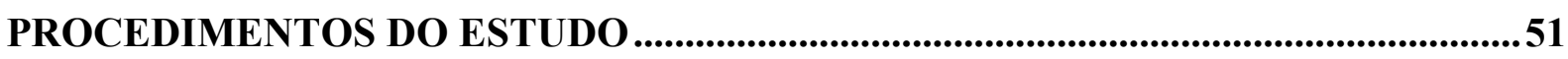

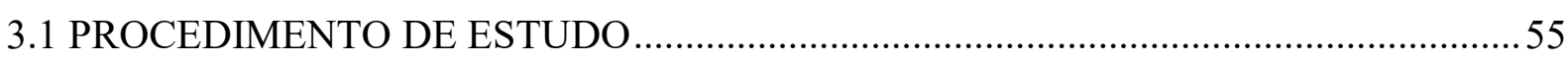

3.2 DETALHAMENTO E PARÂMETROS DOS CENÁRIOS .............................................56

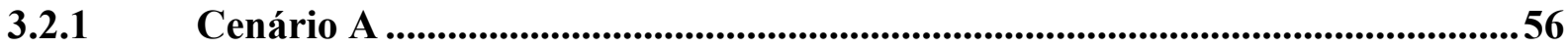

3.2.2 Cenário B

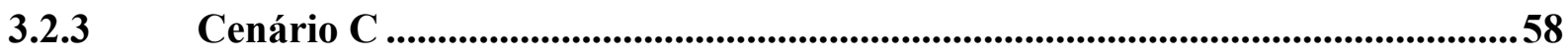

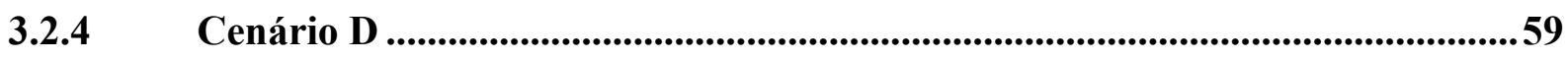

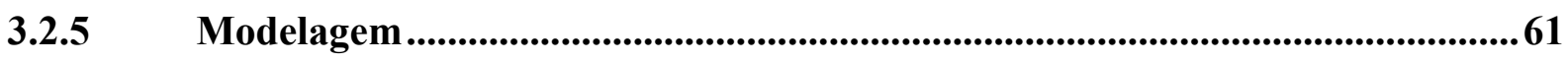


4 IMPLEMENTAÇÃO DOS MODELOS E AVALIAÇÃO DE RESULTADOS 63

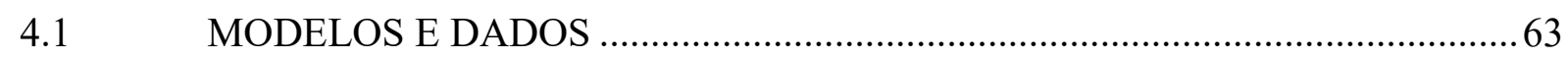

4.1.1 Cenário A …................................................................................................63

4.1.2 Cenário B ..............................................................................................66

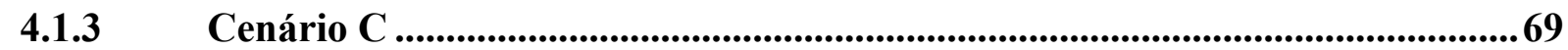

4.1.4 Cenário D ..................................................................................................................74

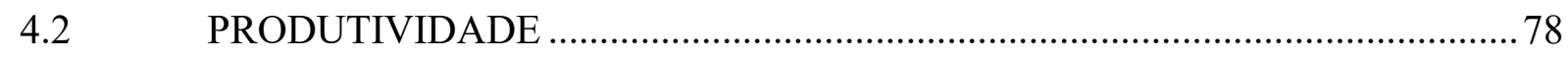

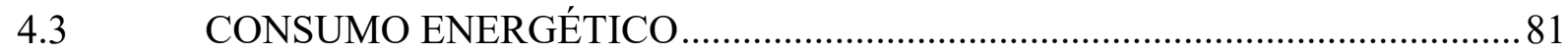

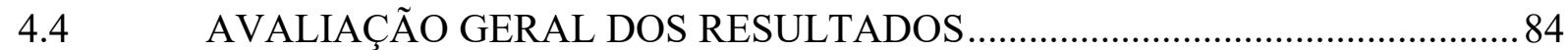

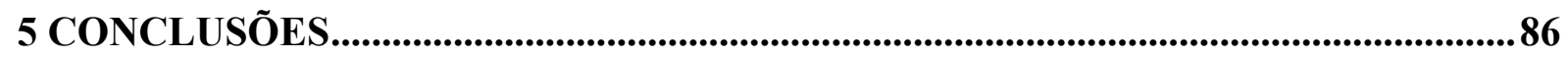

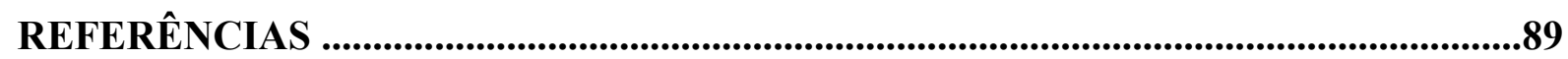




\section{INTRODUÇÃO}

A escassez de recursos energéticos e as dificuldades de abastecimento do sistema energético devido à alta dependência dos fatores climáticos vêm se agravando ao longo dos anos no Brasil. Tais ocorrências têm elevado a pressão sobre as tarifas e contribuído para a instauração da instabilidade no planejamento de investimentos.

$\mathrm{Na}$ atualidade, a sociedade brasileira vive em meio a um cenário crítico de abastecimento energético devido à crise hídrica presente em grandes Estados. Dados do Balanço Energético Anual (EPE, 2018) revelam que, em relação às participações de recursos renováveis em sua matriz energética, o Brasil apresenta uma das maiores taxas, girando em torno de $43,2 \%$.

Este consumo de energia elétrica, embora fomentado pelo consumidor da ponta, tem como maior consumidor unitário o setor industrial, que responde por 31,8\% de todo o consumo nacional. Este fator, com consequências econômicas e ambientais, tem feito com que as indústrias busquem a aplicação de práticas sustentáveis que tenham como objetivo a redução de custos de geração e transmissão e que, principalmente, viabilizem uma gestão sustentável de seu consumo energético.

Face à conjuntura de recursos naturais escassos e à alta demanda, diversos estudos apontam para um potencial significativo de melhoria dos indicadores de eficiência energética na indústria de manufatura através de métodos e estratégias de gerenciamento do consumo de energia elétrica (CHANG et al., 2013). Tal melhoria permitiria, de acordo com Bunse et al. (2010), o aumento da competitividade, por meio da redução do consumo de energia elétrica, bem como o atendimento às novas regulamentações ambientais e de certificações, como a ISO 50001.

No entanto, mesmo com algumas tecnologias disponíveis, correlacionar o uso de energia elétrica com as operações realizadas em sistemas de manufatura tem representado um desafio, dada a complexidade dos sistemas de produção e do grande número de fontes de dados (DIAZ; REDELSHEIMER; DORNFELD, 2011).

Diante desta abordagem de complexidade, inicialmente alguns pesquisadores utilizaram em seus estudos a aplicação do método de simulação por evento discreto em equipamentos isolados, com o objetivo de identificar, através de um método mais simples, as oportunidades de melhorias (MOUZON; YILDIRIM, 2008). Observou-se, no entanto, que a 
avaliação em equipamentos isolados não permite entender e avaliar as oportunidades de um sistema de manufatura de forma abrangente, o que favoreceu o desenvolvimento de análises em sistemas de manufatura completos, considerando-se outras variáveis correlacionadas à ineficiência energética, tais como as paradas de equipamentos, seus estados de energia e o cálculo de estoques intermediários para evitar a ociosidade dos equipamentos (JOHANSSON et al., 2008).

A simulação de sistemas de manufatura vem ganhando cada vez mais espaço no setor industrial devido aos benefícios oriundos de suas análises, uma vez que esta permite que todo o sistema de manufatura possa ser digitalizado e simulado, trazendo o conceito de digitalização para a realidade do setor (CHRYSSOLOURIS et al., 2008).

Com a evolução dos sistemas digitais, da conectividade, da globalização e da competitividade mundial, surge, em meados de 2011, na Alemanha, o conceito "Industrie 4.0", o qual tem sido apontado como a "quarta revolução industrial”, ao trazer uma nova concepção de integração de Sistemas Cyber-Físicos (CPS), com o objetivo de dar autonomia, integração e poder de decisão para os sistemas de manufatura (ACATECH, 2013).

Uma ferramenta potencial para a análise e apoio à tomada de decisão, no que concerne à eficiência energética global de instalações industriais, é o software de simulação Plant Simulation, haja vista que estes sistemas concentram, entre outros recursos, diversas possibilidades de simulações, integrações com dispositivos em tempo real e análise prévia de performance, as quais são essenciais para a medição prévia do consumo em suas diversas esferas (ANTONIOL, 2016).

Sendo assim, o trabalho proposto aborda a simulação de regras de programação da produção para análise e possível incremento de indicadores de eficiência energética em sistemas de manufatura de ciclos curtos a partir de ferramentas de manufatura digital.

\subsection{OBJETIVO GERAL}

Avaliar o consumo global de energia elétrica em um sistema de manufatura com processos de ciclos curtos, através da aplicação de modelos de simulação e, a partir dos resultados, identificar os elementos que auxiliam nas tomadas de decisões e atuam como suporte para novos investimentos e projetos. 


\subsection{OBJETIVOS ESPECÍ́FICOS}

a) apresentar os conceitos da Indústria 4.0 com foco em manufatura digital para realizar análises de consumo de energia nos sistemas de produção;

b) identificar regras de programação que auxiliam na redução do consumo de energia em sistemas de manufatura de ciclos curtos;

c) investigar as oportunidades para redução do consumo de energia;

d) contribuir com o setor empresarial apontando lacunas no uso racional de energia elétrica.

\subsection{JUSTIFICATIVA}

A busca pela eficiência energética vem sendo estudada ao redor do mundo, não apenas com o objetivo de reduzirem-se os custos do consumo de energia como também pela necessidade de aumentar a sustentabilidade no setor industrial, massivamente exigida pelas legislações cada vez mais restritivas em diversos países. Este fato tem pressionado sobremaneira o setor industrial para que haja um uso cada vez mais racional dos recursos energéticos devido às suas emissões de $\mathrm{CO}_{2}(\mathrm{ACATECH}, 2013)$.

Atrelada a este cenário, a dependência dos fatores climáticos da matriz energética brasileira estabelece certo grau de imprevisibilidade quanto aos custos de geração de energia elétrica, o que, de acordo com o Sistema Firjan (FIRJAN, 2017), deve ser considerado como um importante fator para a competitividade empresarial, devendo-se direcionar pesquisas e ações para a busca de eficiência energética.

Como apresentado anteriormente, o setor industrial brasileiro é o maior consumidor de energia elétrica, conforme dados apresentados pelo Balanço Energético Anual (EPE, 2018). O relatório sugere que o advento de novas tecnologias resultaria em uma redução importante no consumo de energia, porém, em virtude da instabilidade econômica do país, novos investimentos se tornam cada vez mais restritos e geralmente direcionados ao produto. Neste caso, uma alternativa plausível para identificar e implementar melhorias com o objetivo de reduzir o consumo de energia elétrica está na utilização de recursos computacionais para realizar simulações em sistemas de produção.

Complementar ao quadro apresentado por Firjan (2017), para que se minimize o impacto dos custos com energia no setor industrial, o próprio setor deve atuar na promoção de soluções 
de resultado mais rápido, que contribuam para a eliminação dos desperdícios de energia elétrica e que não dependam de ações governamentais (MOREIRA, 2008).

Deste modo, os estudos apresentados neste trabalho devem servir como base para estimular este tipo de iniciativas no setor, assim como apresentar de modo prático os conceitos e a utilização de ferramentas de manufatura digital aplicados ao contexto de eficiência energética em sistemas de produção.

\subsection{RELEVÂNCIA}

A aplicação dos conceitos da Indústria 4.0, com foco na redução do consumo de energia utilizando ferramentas de manufatura digital, mostra que as novas tecnologias estão atreladas aos aspectos de sustentabilidade, auxiliando na identificação de oportunidades para eliminar os desperdícios presentes no setor industrial.

A manufatura digital deve ser encarada como um recurso tecnológico para o planejamento de um processo, para a verificação da produtividade e também para a verificação da eficiência dos sistemas de manufatura (SANTOS; BARBOSA, 2015). Além disso, de acordo com Jovanovic e Hartman (2013), a manufatura digital é uma área emergente dentro do PLM, que suporta a colaboração em várias fases do ciclo de vida do produto, contemplando desde os processos de fabricação, design, simulação computacional, manufatura flexível, manufatura enxuta e impressão 3D. Chryssolouris et al. (2008), por sua vez, relatam que a manufatura digital vem se tornando um elemento importante para o setor industrial, muito embora ainda haja um espaço importante para a exploração dos benefícios desta tecnologia. Ocasionalmente, empresas de grande porte possuem maior acesso a este tipo de tecnologia, tal qual a colaboradores qualificados sobre o assunto. Neste contexto, são necessárias contribuições para empresas de médio e pequeno porte, o que este trabalho se propõe a fazer, ao viabilizar que estas corporações se valham desta análise para buscar maior competitividade e sustentabilidade.

Os estudos que abordam a eficiência energética no setor industrial utilizam como ferramentas de análise os softwares de simulação ou modelos matemáticos. Neste cenário, este trabalho traz contribuições ao utilizar os conceitos de manufatura digital integrados aos sistemas de simulação e associados aos efeitos de sustentabilidade ambiental das empresas, sendo esta uma vertente emergente e ainda não profundamente explorada.

Além disso, este trabalho visa conectar os estudos e conceitos analíticos pré-existentes neste tema aos resultados observados na simulação realizada, pois, desta forma, será possível a obtenção do diagnóstico global de eficiência energética em sistemas de manufatura industriais. 


\subsection{METODOLOGIA}

Referente ao tipo de pesquisa, este trabalho prevê a utilização da abordagem quantitativa, sendo classificada como exploratória em relação aos objetivos. O método utilizado é a simulação que, de acordo com Banks et al. (2009), tem se tornado uma das técnicas de análise de sistemas complexos de manufatura mais populares e de melhor custo benefício, tornando possível o estudo do sistema sem que seja necessário construi-lo ou alterá-lo na realidade, procedendo com modificações simuladas nesse sistema a fim de estudar seus resultados (HARREL; GHOSH; BOWDEN, 2004).

O software de simulação computacional Siemens Plant Simulation ${ }^{\circledR}$ foi utilizado como ferramenta para analisar os sistemas de produção e seus respectivos sistemas de energia elétrica neste trabalho. Conforme exposto por Sakurada e Miyake (2009), os simuladores oferecem vantagens como o requerimento de tempo relativamente menor para construção do modelo e a maior facilidade de utilização apoiada em menus e gráficos amigáveis.

É válido salientar que a escolha por uma ferramenta de simulação integrada a um sistema de manufatura digital deve-se ao foco desta pesquisa, que está direcionado para a eficiência energética, considerando-se a relação existente entre esta variável e a produtividade, os processos de fabricação, a programação de produção e a interação entre os ambientes que constituem um sistema de produção.

Como modelo de análise foi utilizada a sequência lógica, conforme expresso na Figura 1:

Figura 01 - Etapas de um modelo de simulação computacional.

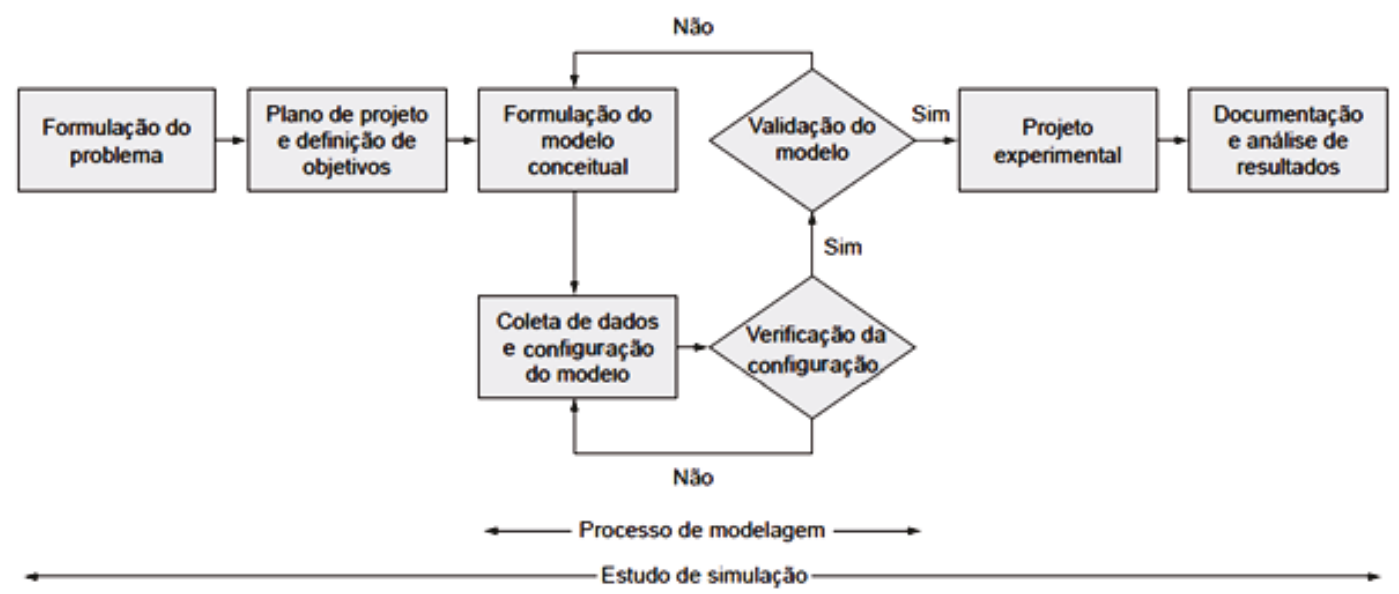

Fonte: BANKS et al. (2009) 


\section{REVISÃO BIBLIOGRÁFICA}

O referencial teórico delimita as fronteiras do que será investigado, proporciona suporte teórico à pesquisa, explicita o grau de evolução - estado da arte - do tema estudado, além de ser um indicativo de familiaridade e conhecimento sobre o assunto para o pesquisador, tal qual expresso por Cauchick (2012). Deste modo, para desenvolver uma fundamentação teórica profunda para o tema, os assuntos serão abordados de acordo com a sua relevância para a pesquisa.

\subsection{A ENERGIA EM SISTEMAS DE MANUFATURA E INICIATIVAS DE PESQUISAS}

O setor industrial é um dos maiores consumidores de energia elétrica em todo o mundo, devido a este fato, todos os sistemas de manufaturas espalhados pelas diversas fábricas contribuem para que este setor tenha esta posição relevante neste cenário energético. Duflou et al. (2012), para ilustrar a importância da indústria em relação à demanda de energia, ressaltam que o consumo de energia global residencial, comercial e de transporte representam, respectivamente, $14 \%, 7 \%$ e $27 \%$ do total, enquanto o uso industrial é responsável por todo o saldo de $51 \%$.

Este contexto, embora diferente em cada país, denota que o setor industrial se mantém sempre entre os maiores consumidores de energia (FERNANDEZ; LI; SUN, 2013). Ainda sobre isso, a energia é o recurso mais fundamental para o crescimento e prosperidade do futuro econômico e seu consumo continuará a crescer nas próximas décadas, com uma estimativa de crescimento de 35\% para a demanda no Brasil até 2030 (EPE, 2018). De forma diferente, a União Europeia vem desenvolvendo diversas políticas para reduzir a dependência de energia elétrica em função do crescimento econômico. De acordo com o relatório da European Commission Eurostat (2013), os países pertencentes a EU possuem uma meta de redução de energia de $20 \%$ até 2020 comparada à energia consumida em 2005.

Conforme apresentado por Seow e Rahimifard (2011), a principal afirmação das pesquisas realizadas nesta área é a de que a eficiência e produtividade do consumo energético nos sistemas de manufaturas necessitam ser cautelosamente examinadas, destacando-se a necessidade de novas metodologias e ferramentas que possam prover um detalhamento do uso de energia, ponto este que pesquisadores acreditam que possa dar suporte à redução do consumo energético e influenciar a tomada de decisões futuras. 
Uma grande quantidade de energia é desperdiçada no setor industrial por máquinas que se mantêm em espera quando subutilizadas. Um método para evitar este desperdício de energia e assim reduzir a emissão de $\mathrm{CO}_{2}$ de uma fábrica é considerar a redução do consumo de energia através da tomada de decisões e de aplicação de regras de programação da produção que suportem o planejamento autônomo dos equipamentos (MOUZON; YILDIRIM, 2008).

As pesquisas realizadas por Cataldo, Scattolini e Tolio (2015) apresentam em suas discussões o entendimento de que para projetar e gerenciar fábricas eficientes em termos de energia, o setor industrial necessita de ferramentas para prever computacionalmente o consumo de energia dos equipamentos e processos. Algumas abordagens nesta linha de pesquisa foram apresentadas por Jahangirian et al. (2010) e Seow e Rahimifard (2011), em seus respectivos trabalhos sobre sistema de manufatura.

Herrmann et al. (2011) afirmam em sua pesquisa que a análise individual de máquinas e equipamentos é necessária, porém não é suficiente para obter-se uma perspectiva holística da eficiência energética dos sistemas de manufatura, sendo a avaliação integrada de linhas e instalações uma nova direção para obtenção de novas oportunidades de melhorias.

A simulação de eventos discretos é utilizada em uma grande quantidade de métodos, em particular, a abordagem amplamente popular introduz o conceito de "Energy Block", ou seja, o comportamento específico de consumo de energia que uma máquina pode assumir em cada um dos seus estados operacionais, como "desligado", "start-up" "warm-up", "stand-by", "processamento" ou "parada", cujo os quais, podemos entender como regras de programação durante a execução dos processos industriais. Ao associar a cada estado operacional de uma máquina um padrão de consumo de energia, identificado por um perfil de potência, é possível calcular o consumo geral de energia das máquinas em diferentes condições operacionais (CATALDO; SCATTOLINI; TOLIO, 2015).

Neste aspecto, Duflou et al. (2012a) apresentam uma avaliação de grande relevância das metodologias e tecnologias que podem ser aplicadas nos diferentes níveis dos sistemas de manufatura, oferecendo uma visão holística acerca desses sistemas - desde equipamentos individuais até toda a corporação -, que possui como objetivo o incremento dos indicadores de eficiência energética. Uma síntese deste estudo é apresentada no Quadro 01: 
Quadro 01 - Metodologias de eficiência aplicáveis aos diferentes níveis dos sistemas de produção.

\begin{tabular}{|c|c|c|}
\hline TIPO & DESCRIÇÃO DO SISTEMA & METODOLOGIAS APLICÁVEIS \\
\hline 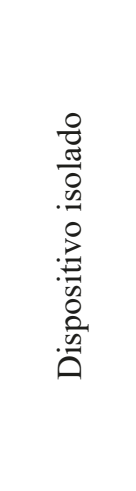 & $\begin{array}{l}\text { Equipamento individual ou máquina- } \\
\text { ferramenta presente no sistema de } \\
\text { fabricação, responsável pela execução } \\
\text { de um processo na unidade. }\end{array}$ & $\begin{array}{l}\text { - Atualização do projeto de máquinas-ferramentas e } \\
\text { aplicação de controle com múltiplos estados pode } \\
\text { aumentar significativamente a eficiência energética sem } \\
\text { afetar a produtividade. A falta de prioridade dos } \\
\text { fabricantes de máquinas para o tema de eficiência } \\
\text { energética abre um espaço de melhoria utilizando-se de } \\
\text { métodos e técnicas já conhecidos; } \\
\text { - Atribuição, durante o planejamento de produção, de } \\
\text { nível de utilização próximo à capacidade nominal das } \\
\text { máquinas; } \\
\text { - Configuração de parâmetros de processo adequados à } \\
\text { operação a ser executada. }\end{array}$ \\
\hline 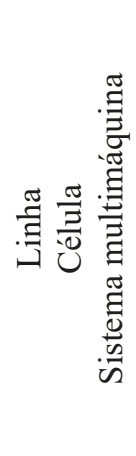 & $\begin{array}{l}\text { Organização lógica de equipamentos no } \\
\text { sistema de fabricação, que atuam em } \\
\text { série ou paralelo com o objetivo de } \\
\text { executar uma tarefa específica como a } \\
\text { fabricação de uma peça ou a montagem } \\
\text { de um conjunto. Equipamentos de } \\
\text { apoio, como esteiras, estão incluídos } \\
\text { neste grupo. }\end{array}$ & $\begin{array}{l}\text { - Valores de demanda contratada e consumo total de } \\
\text { energia elétrica podem ser minimizados através de } \\
\text { métodos de planejamento e aprimoramento suportados } \\
\text { por técnicas de simulação, permitindo assim a avaliação } \\
\text { global da combinação de processos, máquinas e buffers, } \\
\text { bem como aspectos como o tamanho de lotes, a } \\
\text { programação de ordens e a velocidade de produção. } \\
\text { Possibilita, ainda, a análise dos períodos do dia mais } \\
\text { favoráveis para produção perante o aspecto do custo de } \\
\text { energia, devido às tarifas diferenciadas em determinados } \\
\text { horários. }\end{array}$ \\
\hline$\frac{\mathscr{D}}{\frac{\pi}{0}}$ & $\begin{array}{l}\text { Local que abriga vários equipamentos } \\
\text { distintos, que podem ou não estar } \\
\text { logicamente organizados em linhas, } \\
\text { células, etc. Equipamentos de apoio, tais } \\
\text { como geradores de energia e sistemas de } \\
\text { HVAC, estão incluídos neste grupo. }\end{array}$ & $\begin{array}{l}\text { - Aplicação de técnicas de simulação para determinação } \\
\text { de métricas e identificação dos fluxos de energia de } \\
\text { sistemas de produção integrados e complexos; } \\
\text { - Avaliação criteriosa do layout da fábrica durante a etapa } \\
\text { de projeto e instalação de novos equipamentos; } \\
\text { - Dimensionamento adequado de equipamentos e } \\
\text { sistemas auxiliares, tais como compressores de ar e } \\
\text { sistemas de HVAC, de acordo com as necessidades locais } \\
\text { da instalação; } \\
\text { - Planejamento de produção integrado em nível de } \\
\text { unidade, objetivando aprimorar o consumo total de } \\
\text { energia. }\end{array}$ \\
\hline 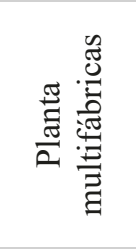 & $\begin{array}{l}\text { Diferentes instalações cuja proximidade } \\
\text { física permite fazer uso de possíveis } \\
\text { sinergias em termos de aprimoramento } \\
\text { de utilização de energia. }\end{array}$ & $\begin{array}{l}\text { - Aplicação de princípios de simbiose industrial, } \\
\text { implementados através do compartilhamento de sistemas } \\
\text { de utilidades e subprodutos entre as indústrias, } \\
\text { objetivando incrementar a eficiência global em termos de } \\
\text { energia favorecendo-se da localização geográfica } \\
\text { propícia. }\end{array}$ \\
\hline 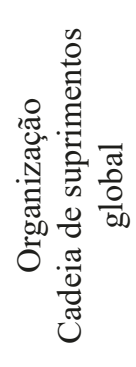 & $\begin{array}{l}\text { Todo o sistema de produção, composto } \\
\text { pelas instalações industriais individuais, } \\
\text { a infraestrutura necessária para suportar } \\
\text { as instalações, bem como a cadeia de } \\
\text { suprimentos envolvida. }\end{array}$ & $\begin{array}{l}\text { - Aplicação de estratégias de geração de energia para } \\
\text { abastecimento próprio das unidades, inclusive a partir de } \\
\text { resíduos provenientes dos respectivos processos } \\
\text { produtivos; } \\
\text { - Seleção adequada dos locais de produção, } \\
\text { armazenamento e distribuição, os quais o consumo } \\
\text { energético pode ser influenciado de acordo com as } \\
\text { condições climáticas locais e eventuais necessidades de } \\
\text { transporte. }\end{array}$ \\
\hline
\end{tabular}

Fonte: DUFLOU et al. (2012a). 
Apesar dos grandes esforços já realizados, tais como a substituição isolada de acionamentos elétricos ou melhorias integrais nos processos de produção, ainda há um potencial significativo na implantação de medidas de eficiência energética economicamente viáveis para a indústria de manufatura (ABELE; BRAUN; SCHRAML, 2015).

Conforme colocado por Abele, Panten e Menz (2015), novas abordagens devem ser desenvolvidas, de modo a possibilitar a implementação de soluções de eficiência energética em sistemas de manufatura dinâmicos, que apresentem condições de demanda e exigências variáveis.

De acordo com Herrmann et al. (2011), diversos estudos mostram a possibilidade de alcance de progressos de 10 a 30\% neste segmento, apenas com a aplicação de tecnologias já disponíveis. Uma vez observada a discrepância entre as soluções disponíveis e o grau de aplicação das mesmas na indústria, métodos adequados de suporte à implementação e avaliação de impacto destas ações promissoras, tais como o desenvolvimento de métricas e indicadores dedicados, se fazem cada vez mais necessários.

Uma característica comum a quase todos os processos de fabricação é a de que, mesmo quando a máquina está ociosa, está consumindo mais de $50 \%$ de sua potência máxima (SALONITIS; BALL, 2013).

As reduções de energia também podem ser alcançadas através das melhorias de processo. Dois exemplos indicativos de um processo de melhoria merecem ser destacados: a) Salonitis e Ball (2013) obtiveram reduções significativas de energia para o caso de moagem através da redução das etapas do processo e do uso de moagem mais fina e melhor planejamento das operações; e b) Diaz, Redelsheimer e Dornfeld (2011), por sua vez, reduziram o consumo de energia durante a moagem através da seleção do caminho ideal da ferramenta.

A eficiência energética dentro de uma fábrica pode ser abordada em vários níveis, conforme indicado por Duflou et al. (2012b). Sendo assim, as melhorias em cada nível terão seus benefícios e esses benefícios serão aditivos.

A filosofia "lean" forneceu benefícios significativos aos sistemas de fabricação através do foco no fluxo e posterior remoção de desperdícios. A aplicação do "lean" concentrou-se no fluxo de material primário para melhorar a entrega do produto ao cliente. Mais recentemente, ferramentas do "lean" foram utilizadas para obtenção de economia de energia através da aplicação direta ou do uso de conjuntos de ferramentas "lean e green" (BERGMILLER; MCCRIGHT, 2009). 
Durante as últimas décadas, a demanda por produtos manufaturados tem crescido, bem como por recursos naturais e energia. Entretanto, o movimento de sustentabilidade exige cada vez mais o uso eficiente de energia nos sistemas de manufatura. Com este objetivo, os sistemas de manufatura precisam evoluir do modelo de "maior ganho com menor capital" para "maior ganho com menor consumo de recursos" (SALONITIS; BALL, 2013).

Para analisar possíveis melhorias nos processos de produção industrial e escolher quais devem ser feitas, várias ferramentas de modelagem e regras de programação das linhas de produção podem ser usadas como suporte à decisão. Desta forma, alguns estudos apresentaram resultados significativos nesta área. Dentre os estudos realizados, há dois métodos de análise de energia que são amplamente utilizados: os métodos analíticos conhecidos como Energy Saving Opportunity (ESO) e Event Discrete Simulation (DES), os quais podem apresentar resultados significativos para o aumento da eficiência energética nos sistemas de manufaturas.

\subsubsection{Métodos analíticos de identificação de oportunidade de economia de energia (ESO)}

Dentre os trabalhos que se destacam e seguem esta metodologia, podem-se citar os conduzidos por Chang et al. (2013), Fernandez, Li e Sun (2013), Sun e Li (2013) e Sun (2014).

Chang et al. (2013) apresentam, em seu trabalho, um método denominado janelas de oportunidades, que tem como objetivo identificar oportunidades em uma linha de produção automotiva com máquinas em série, através do controle de energia elétrica em tempo real. Para quantificar estas oportunidades, os autores desenvolveram um modelo ESO para a linha de produção, que faz as análises através dos eventos aleatórios perturbadores ao funcionamento ideal do conjunto, como quebras e paradas não-programadas. Durante a execução deste modelo, os estados de operação das máquinas são ajustados através de ações de controle coordenadas, visando reduzir o consumo global de energia elétrica. Este estudo analítico indica, através de casos de simulação, que as janelas de oportunidade, por meio do controle proposto, propiciam um elevado potencial de economia de energia sem afetar a produção.

Dentro desta mesma área de pesquisa, Sun e Li (2013) propõem um método semelhante de controle de energia elétrica em tempo real, porém com sistemas de manufatura multimáquinas. O modelo proposto realiza as análises das janelas de oportunidades através da determinação coordenada do modo de operação das máquinas, com o objetivo de reduzir os níveis de consumo de energia, preservando assim, a produtividade do sistema. 
Para realizar os cálculos no modelo, os autores consideraram os dados de tempo de ciclo das máquinas, os modos de consumo de energia elétrica, a capacidade e conteúdo de buffers e o histórico de falhas. Os resultados apresentados, naquele estudo, mostram a eficácia e a eficiência do método proposto no que se refere à aplicação em sistemas de manufatura, bem como um fator adicional: o controle de utilização da capacidade dos buffers, o qual possui um papel fundamental na manutenção do rendimento do sistema quando da aplicação das regras de controle de energia durante as janelas de oportunidade identificadas.

Outros estudos estão buscando analisar a redução da demanda elétrica de sistemas de manufatura nos horários de ponta e não apenas a redução de consumo de energia elétrica. Fernandez, Li e Sun (2013) e Sun (2014) apresentam em seus estudos modelos de controle e utilização de buffers voltados apenas à redução da demanda elétrica durante os horários de ponta em sistemas multimáquinas. O modelo gerencia a construção de estoques intermediários entre as máquinas durante os períodos fora de pico, esta estratégia possibilita a não utilização de determinados equipamentos nos horários de ponta, diminuindo, assim, a demanda no período crítico e os custos operacionais durante este período, que, de forma geral, possuem um custo adicional na tarifa.

Ainda nessa esteira, é válido apontar que os modelos matemáticos apresentados pelos autores foram elaborados a partir do método de programação não-linear com o objetivo de minimizar o custo total de operação do sistema, utilizando-se de parâmetros e fatores como: o custo dos estoques propostos, o custo da energia elétrica consumida/demandada e o custo referente a eventuais perdas de produção durante o período em que alguns equipamentos foram desligados durante o horário de ponta, conforme a definição do modelo (FERNANDEZ; LI; SUN, 2013; SUN, 2014).

Consoante os autores, os resultados obtidos mostraram que a aplicação do método proposto resulta em uma redução significativa do consumo de energia elétrica e dos custos totais para o estudo de caso de uma linha de montagem. Desta maneira, este método se valida como uma alternativa de balanceamento de produção que envolve tanto os aspectos econômicos quanto a adesão a práticas de sustentabilidade (FERNANDEZ; LI; SUN, 2013; SUN, 2014).

Os estudos analíticos apresentados resultaram em oportunidades substanciais para os sistemas de manufatura em análise. Entretanto, em alguns casos a complexidade matemática pode ser uma barreira para a aplicação em grande escala deste sistema e, sendo assim, a integração entre os sistemas de simulação e os conceitos utilizados nos ESOs pode apresentar resultados semelhantes através de uma nova abordagem da manufatura digital. 


\subsubsection{Simulação de eventos discretos (DES)}

A simulação de evento discreto é uma das técnicas de modelagem mais utilizadas desde os primeiros dias de simulação computacional na década de 1950. A proliferação e o desenvolvimento contínuo de softwares de simulação ajudaram a colocá-los como um dos métodos mais empregados nesta área. Nos últimos 50 anos, muitas mudanças ocorreram nas formas em que as simulações são desenvolvidas e utilizadas. Conforme apresentado por Robinson (2005), o histórico de simulação é representado por quatro períodos distintos e cada período aproximadamente equivale a uma única década, a partir do final da década de 1950, a saber:

a) O período pioneiro (1950 a 1960);

b) O Período da Inovação (1960 a 1970);

c) A Revolução (1970 a 1990),

d) A Evolução (1990s até o presente).

Johansson et al. (2008) tratam da simulação como sendo uma abordagem muito eficaz para resolução de problemas e identificação de melhorias. Uma das principais áreas de aplicação para simulação são os sistemas de fabricação, de acordo com Law e Maccomas (1999). No entanto, a análise de múltiplos objetivos não é muito comum na simulação de fabricação. A discussão detalhada de modelagem e simulação pode ser encontrada em vários textos científicos, dentre os mais conhecidos, estão Banks et al. (2004) e Law e Kelton (2000).

A tecnologia de utilização de simulação de eventos discretos tem evoluído rapidamente. Centenas de publicações acadêmicas e novos recursos de software são lançados todos os anos. Os softwares e as linguagens de simulação de evento discreto (DES) foram utilizados para inúmeros propósitos, tais como fluxos de pacientes em saúde, estratégias militares, logística, call centers, restaurantes, etc, sendo, assim, considerados um dos métodos mais versáteis para análise de sistema de manufaturas.

Um dos objetivos da DES é a identificação de melhoria dos lucros com foco na redução de desperdícios quando aplicada aos sistemas de manufatura. Porém, este método vem ganhando espaço na realização das análises dos impactos ambientais gerados pelo setor industrial, como por exemplo, a análise do consumo energético, de emissões de $\mathrm{CO}_{2}$, do consumo de recursos, etc.

Solding e Petku (2005) e Solding e Thollander (2006) descrevem como a DES pode ser utilizada para diminuir o consumo de eletricidade para fundições. De maneira complementar, 
Thiede et al. (2013) assinalam que o uso da simulação de sistemas de manufatura é um caminho promissor para o endereçamento das novas questões relacionadas ao meio ambiente, tais como o consumo de energia elétrica, haja vista o fato de que a considera simultaneamente com outras dimensões tradicionais de análise, quais sejam: custo, tempo e qualidade.

A simulação de eventos discretos vem se tornando cada vez mais importante no novo conceito de manufatura digital, representando sistemas cada vez mais complexos e integrando a realidade com o ambiente de simulação, sendo possível obter dados cada vez mais assertivos e que representam os sistemas de manufatura. Com o advento destas soluções da manufatura digital, as mudanças no planejamento de produção ou melhorias em ideias existentes podem ser simuladas e testadas para seu benefício sem risco. De acordo com Thiede et al. (2013) e Herrmann et al. (2011), normalmente há três paradigmas diferentes relacionados à modelagem e simulação de energia elétrica em sistemas de produção (Figura 02).

a) paradigma $\mathrm{A}$ - ferramentas de simulação de eventos discretos (DES) são utilizadas para simular sistemas de produção e suas variáveis típicas, como o estado dos equipamentos e o tempo de produção. Esta informação é posteriormente transportada para uma ferramenta de avaliação externa, a partir da qual os dados de simulação obtidos são convertidos em variáveis relacionadas à energia elétrica, como o consumo em kWh;

b) paradigma B - apresenta a integração dinâmica de ferramentas distintas - DES e avaliação -, permitindo a consideração das interdependências existentes entre os diferentes sistemas;

c) paradigma $\mathrm{C}$ - todas as características relevantes para a obtenção de dados de energia elétrica e avaliação dos mesmos estão implementadas em apenas uma ferramenta DES. 
Figura 02 - Paradigmas de simulação de energia elétrica em sistemas de manufatura.

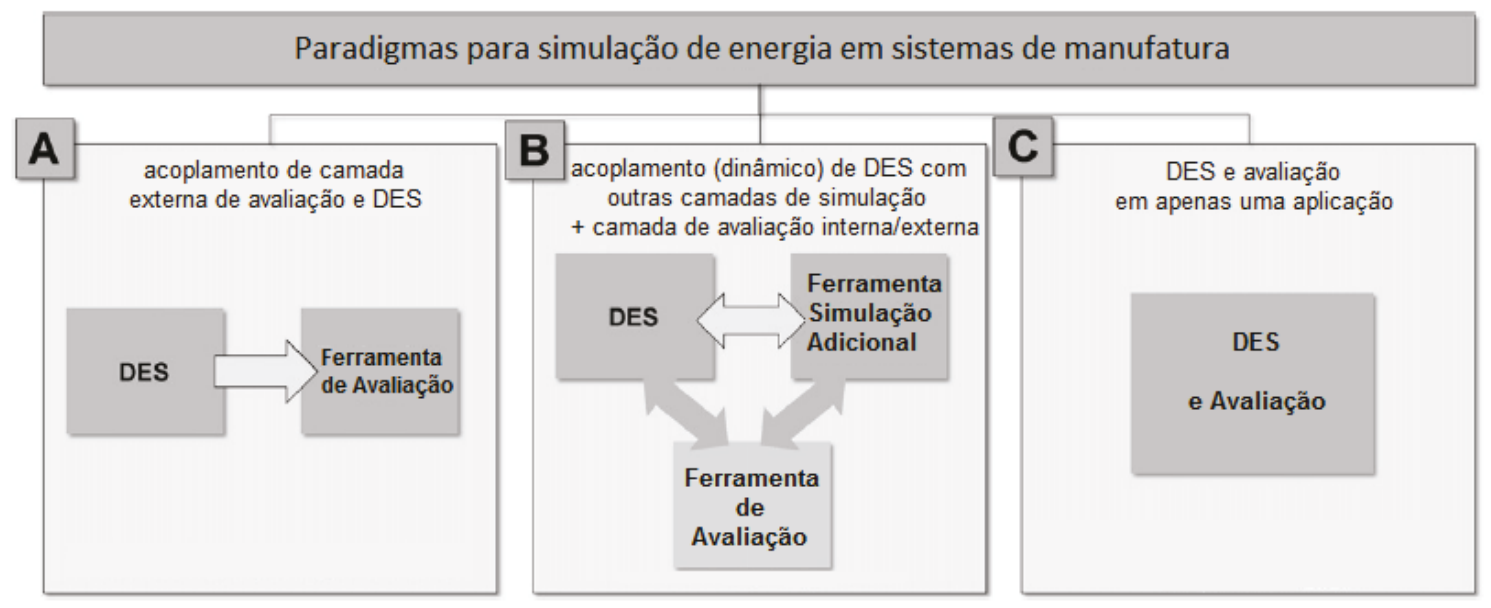

Fonte: HERRMANN et al. (2011).

De acordo com Spreng, Eberhard e Fleissner (2013), uma simulação de energia em um sistema de manufatura deve ser universal e fácil de aplicar, não computacionalmente intensiva e extensível para outros tipos de consumo como água, gás ou ar pressionado.

No entanto, além dos sistemas de produção tratados por estas ferramentas e estudos já realizados, a disposição física das unidades fabris, o comportamento dinâmico dos equipamentos, bem como o dimensionamento e os diferentes estados de manufatura que um recurso produtivo pode assumir durante sua operação, entre outros fatores, podem ter um grande impacto sobre o consumo de energia elétrica nas unidades fabris. Desta forma, a aplicação de ferramentas integradas de manufatura digital permite uma análise mais eficiente e global de sistemas de produção, adicionando novos parâmetros a serem tratados simultaneamente.

Ademais, conforme colocado por May et al. (2015), ferramentas de simulação podem também ser utilizadas em um amplo campo ainda pouco explorado, a fim de estudar o comportamento energético dos recursos produtivos frente a diferentes cenários, possibilitando a obtenção de previsões do consumo de energia elétrica e fornecendo informações pertinentes para o processo de tomada de decisão, tais como a escolha do melhor contrato de fornecimento e os turnos ideais para a operação de uma planta. Estes cenários podem envolver os efeitos obtidos através da aplicação de diferentes instrumentos, tais como o relacionamento entre os estados de energia e os estados de manufatura das máquinas, a gestão de estoques e buffers e o planejamento da produção (MAY et al., 2015). Adicionalmente, os autores informam ainda que ambientes de simulação, quando apoiados adequadamente por indicadores de desempenho, permitem não apenas a avaliação de diferentes conjunturas, mas também o acompanhamento da eficácia das ações de melhoria tomadas ao longo do tempo. 


\subsection{CONCEITOS DA INDÚSTRIA 4.0}

O termo "Industrie 4.0" está sendo utilizado para nomear a próxima revolução industrial - que está prestes a ter o seu lugar na história. Esta revolução industrial foi precedida por outras três na história da humanidade. A primeira revolução industrial foi a introdução de instalações de produção mecânica a partir da segunda metade do século XVIII e foi intensificada ao longo de todo o século XIX. A partir da década de 1870, a eletrificação e a divisão do trabalho (ou seja, o taylorismo) levaram à segunda revolução industrial. A terceira revolução industrial, também chamada de "revolução digital", ocorreu em torno da década de 1970, quando a tecnologia eletrônica avançada e a tecnologia da informação desenvolveram ainda mais a automação dos processos de produção, como se pode constatar em Acatech (2013). A Figura 03 mostra as revoluções industriais que ocorreram ao longo dos anos e a que está acontecendo neste momento.

Figura 03 - Os quatro estágios da Revolução Industrial.

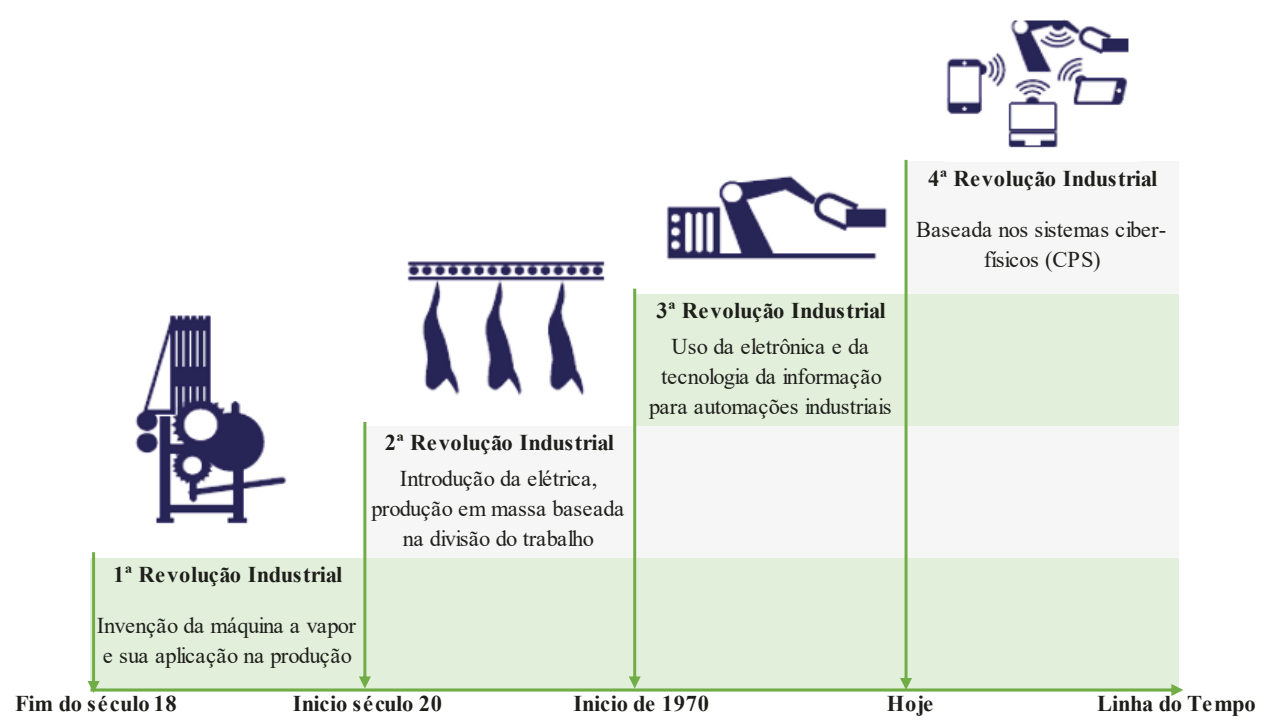

Fonte: Autor adaptado de Acatech (2013).

A "Industrie 4.0" tornou-se conhecida publicamente em 2011, quando uma iniciativa chamada "Industrie 4.0" - uma associação de representantes de negócios, política e academia promoveu a ideia como uma abordagem para fortalecer a competitividade da indústria de manufatura alemã (ACATECH, 2013).

O governo federal alemão apoiou a ideia anunciando que a Industrie 4.0 será parte integrante da iniciativa "Estratégia de alta tecnologia 2020 para a Alemanha", com o objetivo 
de liderar a inovação tecnológica. O "Grupo de Trabalho Industrie 4.0", posteriormente formado, desenvolveu as primeiras recomendações para a implementação, que foram publicadas, em abril de 2013, pela ACATECH (Academia Alemã de Ciência e Engenharia), que representa as comunidades científicas e tecnológicas alemãs, no país e no exterior. Como uma academia de trabalho, a ACATECH apoia os formuladores de políticas e a sociedade, fornecendo avaliações técnicas qualificadas e recomendações voltadas para o futuro. Naquela publicação, Kagermann e outros autores, descrevem sua visão da Industrie 4.0 da seguinte forma:

\begin{abstract}
No futuro, as empresas estabelecerão redes globais que incorporem suas máquinas, sistemas de armazenagem e instalações de produção sob a forma de Sistemas CyberFísicos (CPS). No ambiente de fabricação, esses sistemas compreendem máquinas inteligentes, sistemas de armazenamento e instalações de produção capazes de trocar informações de forma autônoma, desencadear ações e controlar-se independentemente. Isso facilita melhorias fundamentais para os processos industriais envolvidos na fabricação, engenharia, uso de materiais e cadeia de suprimentos e gerenciamento do ciclo de vida. As fábricas inteligentes que já começaram a aparecer e empregam uma abordagem completamente nova para a produção. Os produtos inteligentes são identificáveis de forma única, podem estar localizados em todos os momentos e conhecem sua própria rastreabilidade, status atual e rotas alternativas para atingir seu estado alvo. Os sistemas de fabricação incorporados são verticalmente conectados em rede com processos de negócios dentro de fábricas e empresas e conectados horizontalmente a redes de valores dispersos que podem ser gerenciados em tempo real - desde o momento em que uma ordem é colocada até a logística de saída. Além disso, eles habilitam e exigem engenharia de ponta a ponta em toda a cadeia de valor (ACATECH, 2013, p.07).
\end{abstract}

Diversos estudos estão buscando decifrar um roteiro adequado para mostrar a estrutura principal da indústria 4.0. A Acatech (2013) apresenta, em seus estudos, o conceito demonstrado pela Figura 04. O modelo está basicamente conectado à "Internet of Things" (IoT) e "Internet of Services" (IoS) e utiliza estes conceitos como base para suportar cinco grandes pilares: "smart mobility", "smart logistics", "smart building", "smart product" e "smart grids". Sendo estes pilares encarregados de sustentarem a "smart factory" através da utilização de Sistemas Cyber-Físicos (CPS). 
Figura 04 - Modelo conceitual da Indústria 4.0.

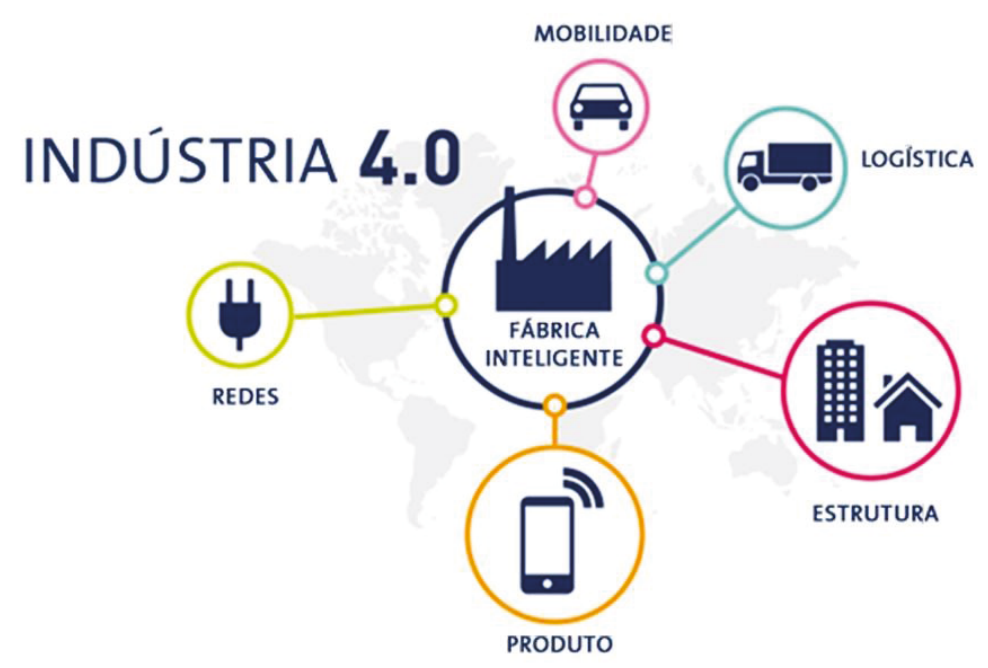

Fonte: Autor adaptado de Acatech (2013).

Para Hewitt (2002), a evolução da manufatura possui um papel importante para a comunidade mundial, em especial para países europeus, devido à perda de competitividade que vem afetando diretamente a economia do setor industrial, o envelhecimento da população e a concorrência dos países em desenvolvimento que possuem custos mais competitivos. O comitê de política econômica europeia (EUROPEAN COMMISSION, 2008) afirma que a população em idade ativa (de 24 a 60 anos) vai reduzir cerca de 48 milhões (16\%), enquanto os idosos atingirão o patamar de 58 milhões até 2050, o que aumenta a pressão econômica, uma vez que a população ativa, que tem a função de sustentar a economia do país, se reduz.

Hoje, a eficiência energética já é um requisito importante para a manufatura. Um facilitador chave para atendê-la é a capacidade de reduzir sistematicamente as partes inativas de uma linha durante as quebras na produção. A indústria 4.0 vem com o objetivo de utilizar soluções digitais para identificar e mapear estas oportunidades na área de eficiência energética, softwares capazes de simular e integrar a CPSs serão amplamente utilizados nesta nova revolução industrial, como denota Acatech (2013). A Figura 05 ilustra um exemplo comum nas indústrias - a variação do consumo de energia em função do tempo, em que se pode identificar períodos de picos, vales e até mesmo o de não-consumo. Estes aspectos podem ser identificados através das ferramentas de digitalização que compõem a indústria 4.0 e podem auxiliar na identificação de oportunidades e na construção de regras de programação para reduzir o consumo de energia. 
Figura 05 - Reduções potenciais durante paradas não-planejadas nos sistemas de manufatura.

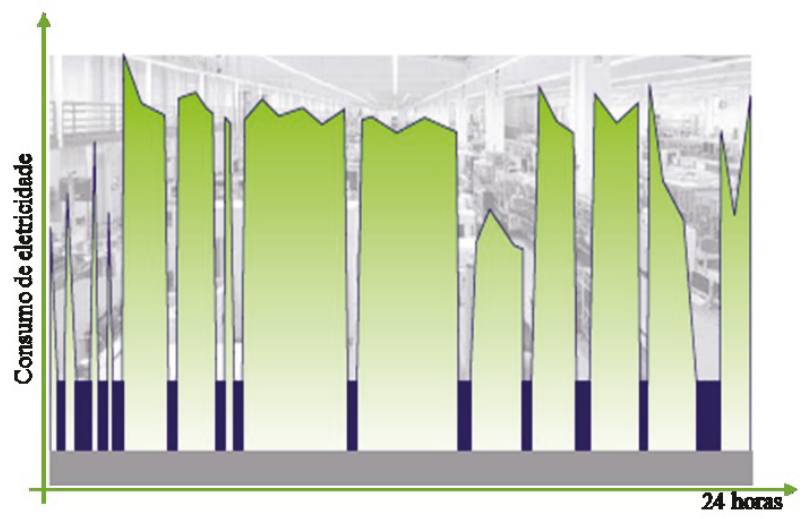

Fonte: ACATECH (2013).

Os produtos e seus sistemas de fabricação estão se tornando cada vez mais complexos. Isto é resultado do aumento das funcionalidades, da personalização dos produtos, dos requisitos de entrega cada vez mais dinâmicos, da crescente integração de diferentes disciplinas técnicas e organizações e das formas de cooperação que mudam rapidamente entre as diferentes empresas.

A modelagem pode atuar como facilitador para gerenciar essa crescente complexidade. Os modelos são uma representação de um cenário real ou hipotético que inclui apenas os aspectos relevantes para a questão em análise. Além disso, eles constituem uma estratégia importante no mundo digital e têm importância central no contexto da Indústria 4.0.

A digitalização é um tema que vem sendo discutido anteriormente à introdução da Indústria 4.0. No que tange ao foco das práticas industriais, Chryssolouris et al. (2008) apontam, ainda que de modo breve, que a manufatura digital tem seu objetivo no emprego de consistentes e abrangentes métodos digitais de planejamento e validação através de computador, envolvendo desde o desenvolvimento do produto até o planejamento da produção e instalações. Os mesmos autores informam também que a manufatura digital possui a capacidade de:

a) reduzir o tempo e custo de desenvolvimento;

b) integrar o conhecimento de diferentes departamentos e processos de manufatura;

c) integrar a manufatura descentralizada em função da crescente diversidade de produtos e partes produzidos em diferentes plantas,

d) focar as empresas de manufatura em seus objetivos, visando trabalhar com eficiência na sua rede de fornecedores e colaboradores em um processo de engenharia colaborativa que tem como base a tecnologia da informação. 
De acordo com a Acatech (2013), a aplicação da Indústria 4.0 envolve a atualização significativa das competências e capacidades digitais de uma empresa e implica mudanças em grandes partes da organização. Por ser uma transformação altamente complexa, geralmente levará vários anos, o que faz com que esta deva ser planejada e implementada de forma a garantir que impactos positivos sobre a rentabilidade - ou seja, crescimento e eficiência ocorram em vários estágios ao longo da transformação. Os benefícios devem ser visíveis em qualquer ponto do processo de transformação, a fim de suportar seu sucesso geral. Esta abordagem permite vitórias rápidas, enquanto conduz-se para o objetivo de transformação geral.

Esta estratégia requer uma abordagem passo-a-passo para o desenvolvimento da empresa. O índice de maturidade da Acatech (2017) para a Indústria 4.0 fornece às empresas orientação para a transformação ágil e para aprendizados. O índice apresenta seis estágios de desenvolvimento consecutivos para quatro áreas-chave de cada empresa. A Figura 06 representa os estágios de desenvolvimento sugeridos e cada estágio baseia-se no anterior, descrevendo-se os recursos necessários para alcançá-los e os benefícios resultantes para a empresa.

Figura 06 - Estágios de desenvolvimento da Indústria 4.0.

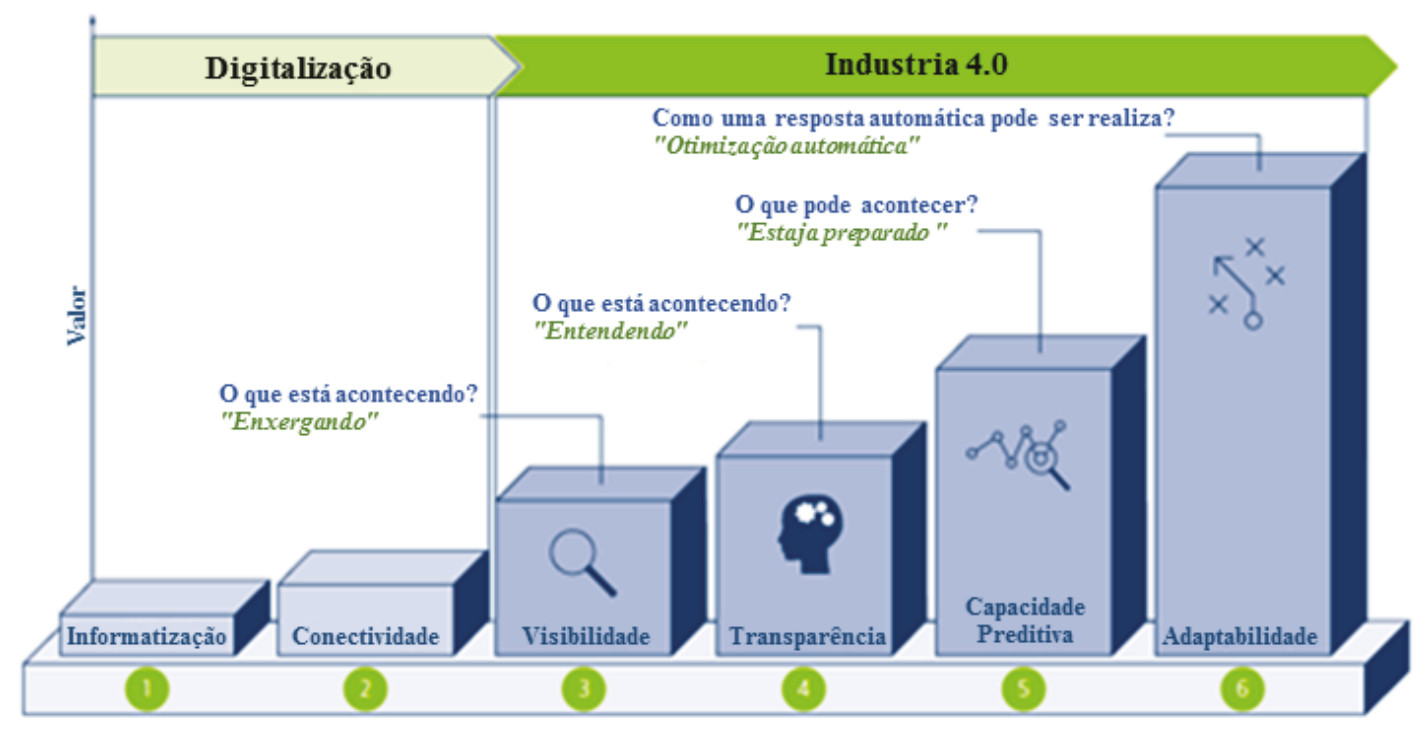

Fonte: Autor adaptado de ACATECH (2017).

De forma complementar, o índice de maturidade da Acatech (2017) contempla as áreaschave de uma empresa (Figura 07). 
Figura 07 - Índice de maturidade da Indústria 4.0.

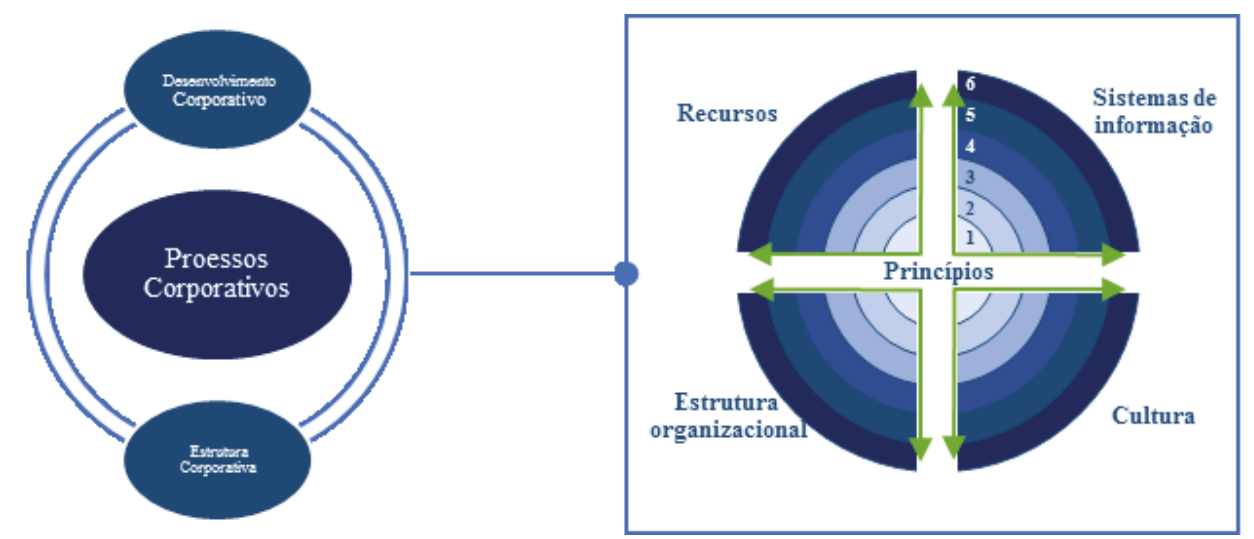

Fonte: Autor adaptado de ACATECH (2017).

Através deste índice, que visa suportar o desenvolvimento da Indústria 4.0 nas empresas, pode-se identificar que dois estágios se encontram em uma etapa anterior, nomeada de digitalização. Esta etapa inicial atua como uma preparação digital com o intuito de estabelecer todos os recursos e conceitos básicos para que os estágios futuros possam ser percorridos.

Diante deste cenário e dos estudos apresentados, a digitalização deve ser aplicada aos sistemas de manufatura para suportar os conceitos e a implementação da Indústria 4.0.

\subsubsection{Manufatura Digital}

A digitalização vem assumindo um espaço cada vez maior na engenharia de manufatura. Consoante ao que fora apresentado anteriormente, a indústria 4.0 requer uma base digital sólida para que os demais conceitos possam ser aplicados. Sendo assim, para o setor industrial, a manufatura digital se tornou o primeiro passo a ser dado.

Sobre isso, Chryssolouris et al. (2008) asseveram que a manufatura digital tem sido considerada, na última década, como um conjunto altamente promissor de tecnologias para reduzir os tempos e os custos de desenvolvimento de produtos, do mesmo modo que o tem sido, para o trabalho, a necessidade de personalização, aumento da qualidade do produto e uma resposta mais rápida ao mercado.

As ferramentas de modelagem permitem aos engenheiros o desenvolvimento de modelos virtuais do produto, a definição de processos de fabricação e a performance operacional dos sistemas de manufaturas. Através destes parâmetros, os engenheiros conseguem avaliar, de forma holística, o caso em questão. Além disso, a utilização destas ferramentas digitais auxilia na identificação de muitos erros de projeto do produto, fazendo com 
que estes sejam evitados e melhorados. Outro aspecto relevante é a redução dos tempos necessários para o desenvolvimento dos produtos e processos através da utilização das soluções de manufatura digital (SLANSKY, 2006).

Chryssolouris et al. (2008) salientam que a manufatura digital tem como objetivo o emprego de métodos digitais de planejamento e validação através de soluções computadorizadas, envolvendo praticamente todas as áreas de uma empresa, desde o desenvolvimento do produto até o planejamento da produção e instalações. Outrossim, os mesmos autores apresentam as capacidades que a manufatura digital implementa: redução do tempo e custo de desenvolvimento; integração do conhecimento de diferentes departamentos e processos de manufatura; integração da manufatura descentralizada em função da crescente diversidade de produtos e partes produzidas em diferentes plantas; e o foco nos objetivos das empresas de manufatura, visando trabalhar com eficiência na sua rede de fornecedores e colaboradores, através da engenharia colaborativa que tem como base a tecnologia da informação.

Gama e Costa (2009) apresentam o Product Lifecycle Management (PLM) como um dos conceitos e ferramentas que integram a manufatura digital, apoiando de forma completa as áreas da engenharia de processos, desenvolvimento de produtos e logística, se preocupando com a máxima eficiência dos recursos de produção e utilização da fábrica, melhores práticas e otimização de investimentos. Além disso, o PLM é capaz de integrar pessoas, dados, processos e sistemas de negócios e oferecer uma estrutura centralizada de informações do produto de forma colaborativa dentro do conceito de empresa estendida, ou seja, inclui a própria empresa, clientes, parceiros e fornecedores.

De acordo com De Carli, Delamaro e Salomon (2010), a manufatura digital integra os seguintes processos: desenvolvimento, teste e otimização do produto; desenvolvimento e otimização dos processos de produção; projeto e melhoria da planta; planejamento e controle das operações produtivas.

Outros autores afirmam ainda que a Manufatura Digital representa um marco importante na evolução do PLM, agregando um conjunto de softwares integrados que permitem aos planejadores de manufatura validar seus processos, aprimorar e sincronizar a produção ao longo de toda a cadeia produtiva, sendo, também, passíveis de simulação os aspectos de ergonomia e movimentação dos operadores humanos na linha produtiva (CÁCERES; CASTILHO; ROSÁRIO, 2011).

Gama (2011) conceitua sistemas de Manufatura Digital como um conjunto abrangente de ferramentas interdisciplinares. De maneira geral, os sistemas de Manufatura Digital se 
estruturam a partir de diversas ferramentas de software para concepção, simulação e análise de manufatura (CAD-Computer Aided Design; CAE-Computer Aided Engineering; CAMComputer Aided Manufacturing; CAT-Computer Aided Testing).

Chryssolouris et al. (2008), por sua vez, afirmam, em seu estudo, que a manufatura digital incorpora tecnologias para a representação virtual de fábricas, edifícios, recursos, equipamentos de sistemas de máquinas, pessoal trabalhista e suas habilidades, bem como para uma maior integração do desenvolvimento de produtos e processos através de modelagem e simulação, o que auxilia na definição do produto e das atividades necessárias para a produção nas linhas de fabricação, além de auxiliar na transformação do conhecimento tácito em conhecimento tangível por meio da digitalização dos processos e procedimentos.

\subsection{INDICADORES DE DESEMPENHO (KPI) VOLTADOS À EFICIÊNCIA ENERGÉTICA EM MANUFATURA}

Medir e direcionar os desempenhos energéticos das fábricas e seus subsistemas é o primeiro passo crítico para entender seu comportamento energético, identificar oportunidades de gerenciamento de energia e avaliar economias de energia (BENEDETTI; CESAROTTI; INTRONA, 2016). Segundo Bunse et al. (2010), tornou-se evidente a necessidade de KPIs exclusivos voltados à eficiência energética. Adicionalmente, os mesmos autores afirmam ainda que KPIs apropriados devem não só permitir a comparação dos perfis de consumo de energia elétrica entre máquinas e processos, mas também possibilitar a avaliação do desempenho de eficiência energética junto a outras empresas e organizações.

Autores como Herrmann et al. (2011), Thiede et al. (2013), May et al. (2016) e May et al. (2015) apresentam em seus estudos a perspectiva de que o desempenho energético, como a maioria dos desempenhos de fabricação, vem de uma rede de interconexões entre sistemas físicos e sistemas de gerenciamento e controle, e não pode ser efetivamente estudado nem otimizado pela análise separada e única dos sistemas de energia.

Nas últimas décadas, os padrões como ISO 50001: 2011 voltados para eficiência energética vêm ganhando espaço tanto no âmbito acadêmico quanto no setor industrial. Portanto, ampliou-se a necessidade de se desenvolver indicadores de desempenho chaves (KPIs) relacionados à energia. De fato, a configuração desses indicadores é uma atividade crucial para a formulação de políticas e o controle operacional em qualquer nível de agregação (equipamentos, departamentos, plantas, países), pois permitem a coleta e a análise pronta de 
informações relacionadas à energia e, consequentemente, a avaliação do potencial de otimização e de melhorias que possam ser implementadas.

Os principais objetivos da definição de KPI voltados para a eficiência energética de acordo com González, Palacin e Batty (2015) são:

a) Extrair apenas a informação mais relevante sobre o desempenho energético do sistema, a fim de limitar seu número;

b) Fornecer uma imagem precisa e global do desempenho energético atual, o que é essencial para ajudar a identificar medidas efetivas de poupança de energia;

c) Facilitar a definição de futuros objetivos de desempenho, ao mesmo tempo em que fornece um mecanismo para monitorar o progresso das medidas de eficiência energética implementadas.

Bunse et al. (2010) e May et al. (2015) propõem em seus estudos uma possível categorização para os indicadores de eficiência energética, que podem ser: "Agregado"; "Desagregado"; ou "Processo/Equipamento". Os indicadores construídos em um nível agregado referem-se, principalmente, a indústrias, empresas ou usinas e são usados para fins de engenharia ou de formulação de políticas, enquanto os indicadores construídos em um nível de processo/equipamento são geralmente referidos a unidades de trabalho únicas ou equipamentos e são utilizados para monitorar sua eficiência e, em uma perspectiva mais ampla, para fins de controle operacional, o que pode ser melhor visualizado no Quadro 02:

Quadro 02 - Níveis de agregação de KPI voltados a eficiência energética.

\begin{tabular}{|l|c|c|}
\hline NÍVEL DE AGREGAÇÃO & NÍVEL DECISÓRIO & ESCALA \\
\hline Agregado & Estratégico & Empresa - Planta \\
\hline Desagregado & Tático & Centro de trabalho \\
\hline Processo / Equipamento & Operacional & Unidade de trabalho \\
\hline
\end{tabular}

Fonte: Autor adaptado de MAY et al. (2015).

Bunse et al. (2010) destacaram a importância dos KPI relacionados à energia e à necessidade fundamental de identificação de ineficiências dentro do consumo de energia de uma planta, particularmente, enfatizando-se o potencial de melhoria no nível da máquinaferramenta. Consoante os autores, têm-se a existência de uma série de KPIs relacionados à energia, e que, de forma resumida, estes são categorizados em dois grupos:

a) Econômicos/financeiros: custo total de energia, custo de energia/unidade, entre outros; 
b) Físicos: energia consumida/unidade produzida; consumo total de energia, entre outros.

Ainda de acordo com os estudiosos, não há um indicador de eficiência energética único que possa ser aplicado a todas as situações e cenários, o que os faz apontar para a relevância de que os indicadores adequados possam ser definidos de acordo com a decisão a ser tomada ou com a ferramenta de decisão aplicada.

Seguindo este princípio, May et al. (2015) complementam que, para avaliar completamente a eficiência ou a eficácia energética de um equipamento, apenas a visão baseada no tempo não é suficiente. Deste modo, os autores apresentam a importância de se criarem os indicadores de desempenho chaves relacionadas à energia (e-KPI), pois a grande maioria dos indicadores atuais de desempenho energético são calculados através de medidas agregadas do consumo de energia (por exemplo, $\mathrm{kWh} / \mathrm{mês}$ ou $\mathrm{kWh} /$ parte). Esta abordagem não possui uma consideração minuciosa das relações causa-efeito entre estados de fabricação (ou seja, causas de ineficiências de energia do recurso produtivo), configurações de máquina e consumo de energia.

O e-KPI proposto por May et al. (2015) é apresentado conforme as etapas abaixo:

a) Estados de energia: é a representação do consumo do equipamento - W para cada período de tempo, em função do estado do equipamento, o qual pode ser potencialmente afetado por decisões tomadas pela gestão do recurso ou do sistema de produção, conforme apresentado no Quadro 03:

Quadro 03 - Estados de energia.

\begin{tabular}{|c|c|}
\hline $\begin{array}{l}\text { ESTADOS DE } \\
\text { ENERGIA }\end{array}$ & DESCRIÇÃOO \\
\hline Desligado & Equipamento está desligado: nenhum consumo de energia elétrica é requerido. \\
\hline Desenergização & Energia elétrica é consumida para o desligamento do equipamento. \\
\hline Standby & $\begin{array}{l}\text { Equipamento apresenta a maioria dos componentes desligados e não está pronto } \\
\text { para processar peças. Apenas alguns componentes são mantidos ativos e consomem } \\
\text { energia elétrica, a fim de reduzir o tempo de reativação do equipamento. }\end{array}$ \\
\hline Manutenção & $\begin{array}{l}\text { Equipamento está sendo reparado com algumas ações específicas que necessitam } \\
\text { de energia elétrica. }\end{array}$ \\
\hline Operacional & $\begin{array}{l}\text { Equipamento não está processando peças, porém mantém energizados todos os } \\
\text { componentes necessários para voltar a produzir imediatamente caso solicitado. }\end{array}$ \\
\hline Setup & $\begin{array}{l}\text { Energia elétrica é consumida para troca de ferramenta ou ajuste do equipamento } \\
\text { para produção de um produto diferente do anterior. }\end{array}$ \\
\hline Energização & Energia elétrica é consumida para a inicialização do equipamento pós desligamento. \\
\hline Processamento & Equipamento está processando peças. \\
\hline
\end{tabular}

Fonte: Autor adaptado de MAY et al. (2015). 
b) Estados de manufatura: os estados de manufatura definem uma condição de ineficácia que impacta o consumo de energia elétrica do próprio recurso analisado e foram classificados pelos autores conforme o Quadro 04:

Quadro 04 - Estados de manufatura.

\section{ESTADOS DE MANUFATURA \\ DESCRIÇÃO}

Ausência e bloqueio

Inatividade devido a motivos de gestão, relativos ao planejamento da produção (operações de carga e sequenciamento).

Esperando ferramenta Inatividade causada pela ausência de ferramenta na máquina.

Se a empresa trabalha em 1 ou 2 turnos por dia, as máquinas são

Início diário reiniciadas diariamente. Se a empresa trabalha em 3 turnos com 5 dias de trabalho, a máquina é reiniciada após o fim de semana.

Início pós feriados Reinício de equipamentos pós feriados.

Setup

Troca de ferramenta ou ajuste do equipamento para produção de um produto diferente do anterior.

Ausência de Ordens (MO) Inatividade causada pela ausência inesperada de ordens de produção.

Ausência de Materiais (MM) Inatividade causada pela ausência inesperada de matéria-prima.

Teste e Amostragem Máquina está processando lotes para teste e amostragem.

Microparadas Microparadas de máquina.

Manutenção corretiva

Período no qual a máquina permanece em estado de quebra/manutenção não-programada.

Manutenção planejada Período no qual a máquina permanece em manutenção programada.

Rejeitos durante start up

Rejeitos / Retrabalho em

produção durante a produção. Intervalo utilizado para a produção de peças rejeitadas durante o start up da máquina.

Paralisações Paralisações dos colaboradores que afetem o desempenho das máquinas.

Fonte: Autor adaptado de MAY et al. (2015).

c) Relação entre os estados de energia e os estados de manufatura: após a identificação dos estados de manufatura e energia para o recurso produtivo, os autores buscaram estabelecer ligações entre ambos, representando assim o impacto específico que um estado de manufatura tem em um determinado estado de energia, conforme a Figura 08. 
Figura 08 - Relação entre os estados de energia e os estados de manufatura.

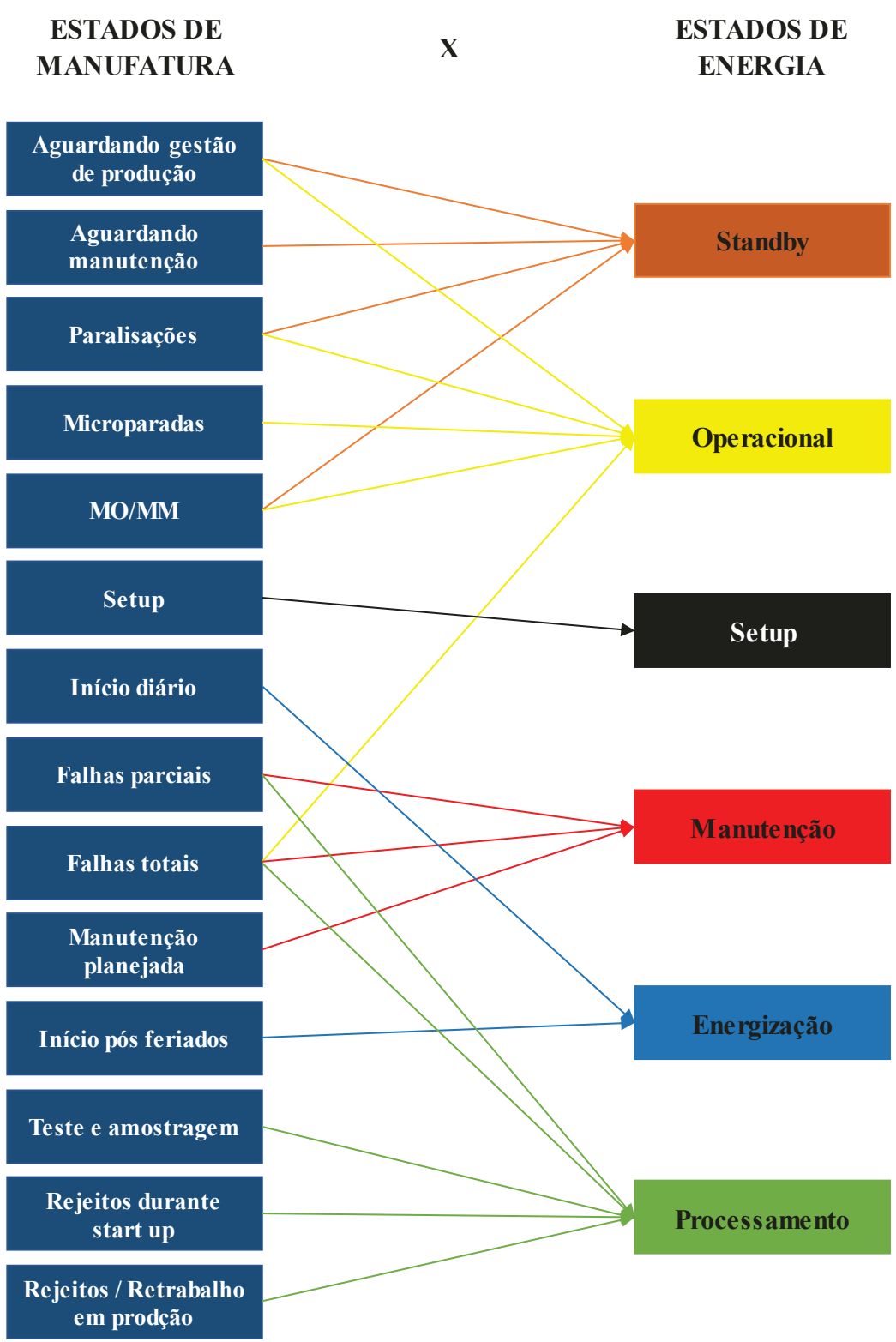

Fonte: Autor adaptado de MAY et al. (2015).

d) Diagrama de energia: apresentado na Figura 09, ilustra o consumo de energia elétrica associado a cada estado de manufatura, agregando os intervalos de tempo - $\mathrm{T}-$ nos quais a máquina tenha gasto um determinado estado de energia - W. As parcelas de consumo de energia elétrica apresentadas no diagrama são apenas ilustrativas - sem escala -, tendo como objetivo, neste estudo, apenas a representação do conceito proposto pelos autores. Os pequenos retângulos são os estados de manufatura, os quais estão associados às respectivas potências elétricas através das setas superiores do diagrama. O primeiro pilar à esquerda representa o total de energia elétrica consumida 
no tempo teórico de produção, sendo que os demais pilares representam a estratificação das parcelas correspondentes aos diferentes estados de manufatura até a obtenção do percentual referente ao consumo de energia elétrica que gera valor, ou seja, a energia útil diretamente associada à produção de unidades vendáveis.

Figura 09 - Diagrama de energia.

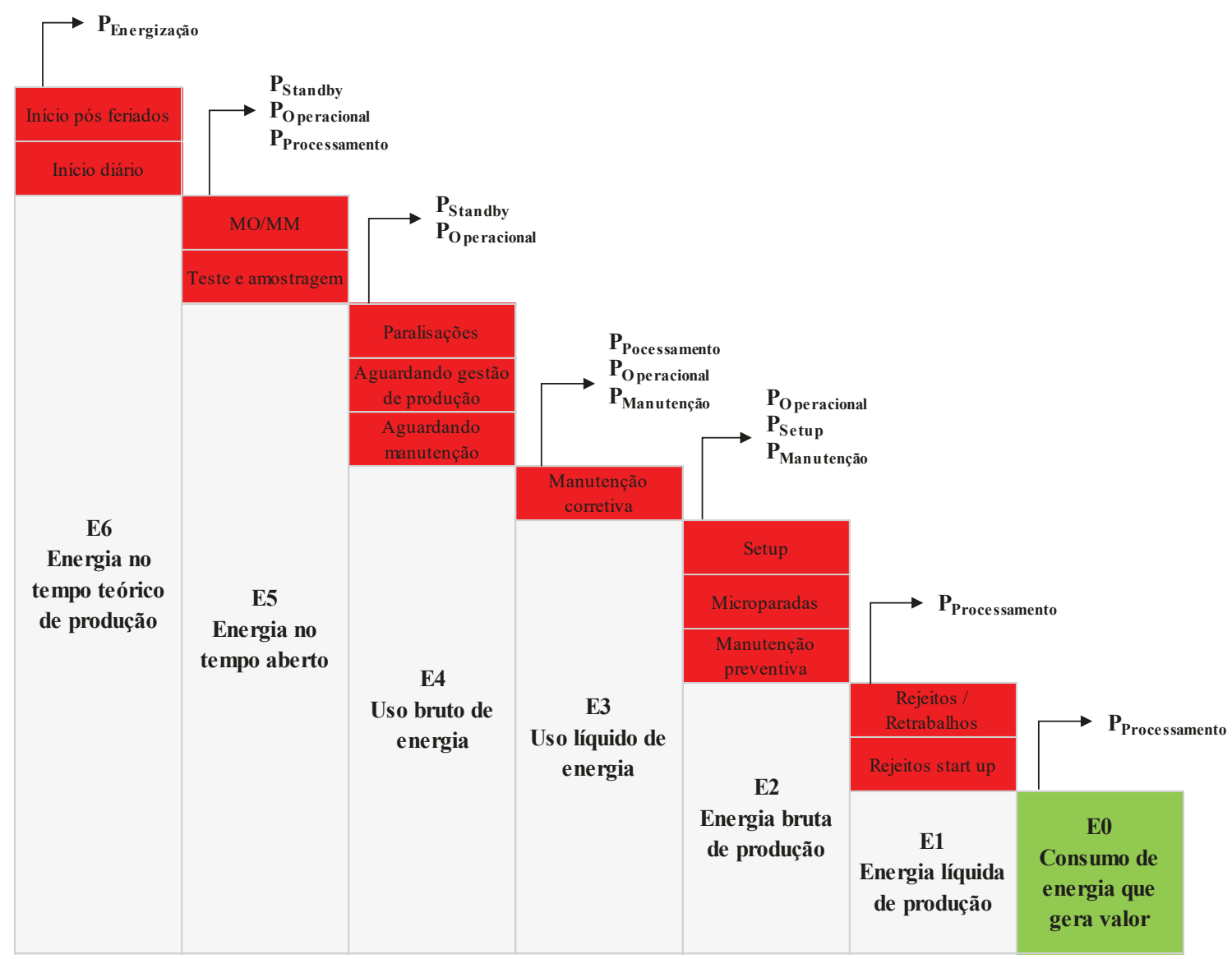

Fonte: Autor adaptado de MAY et al. (2015).

e) Lean Energy Indicador: é uma métrica global, a qual apresenta o quão eficiente é a utilização do equipamento na produção em termos de consumo de energia, representando a razão entre a energia consumida para a produção de produtos vendáveis e o consumo geral de energia do equipamento. Este indicador é obtido pela divisão entre a energia elétrica que gera valor e o consumo total de energia elétrica durante o tempo de produção teórico, conforme apresentado na equação (1): 
Lean Energy Indicator $=\frac{\text { Consumo de Energia Elétrica que Gera Valor }}{\text { Consumo Total de Energia Elétrica }}=\frac{E 0}{E 6}$

Além disso, o detalhamento dos demais fatores de análise de energia baseados nos pilares é apresentado no Quadro 05, a seguir:

Quadro 05 - Fatores de análise de energia elétrica.

FATOR

Qualidade

(Equality)

Saturação

(Esat)

Disponibilidade

(Evail)

Utilização

Utilização
$\left(\mathrm{E}_{\text {usage }}\right)$

Inicialização

(E $E_{\text {opening }}$ )
DESCRIÇÃO

FÓRMULA

Energia elétrica desperdiçada devido a problemas de qualidade (retrabalhos e rejeitos).

$\frac{E 0}{E 1}$

Energia elétrica desperdiçada devido a eventos que retardam a produção do recurso no tempo disponível para operação, tais como microparadas, ajustes e setups.

$E 1$

$\overline{E 2}$

Energia elétrica desperdiçada devido à indisponibilidade do equipamento - manutenção corretiva.

$\frac{E 2}{E 3}$

Energia elétrica desperdiçada devido ao desuso do equipamento, associado a causas relacionadas com a gestão do sistema de produção, tais como planejamento da produção, falta de encomendas externas e matérias-primas, dentre outros fatores.

$\frac{E 3}{E 5}$

Energia elétrica desperdiçada devido às inicializações realizadas no equipamento em períodos como o início de um dia e o retorno pós finais de semana e feriados.

Fonte: Autor adaptado de MAY et al. (2015).

Conforme as etapas apresentadas por May et al. (2015), o quadro de fatores propostos possibilita a identificação das áreas com maior potencial de atuação para o incremento da eficiência energética global do sistema, pois quanto mais distante o fator esteja do valor ideal 1 - maior será a ineficiência no sistema de manufatura, sendo assim, maior será a necessidade de uma intervenção dentro da área definida pelo pilar associado ao indicador e seus respectivos estados de manufatura.

Desta forma, verifica-se, através da métrica apresentada por May et al. (2015), que os e-KPI possuem grande relevância na análise de eficiência energética e que a área de manufatura ainda é pouco explorada na concepção deste e-KPI, além de que o desenvolvimento destes indicadores possui papel preponderante no apoio e interpretação das causas pelas quais parte do consumo de energia elétrica atribuído à produção de um item não esteja relacionada a uma atividade que agregue valor ao produto final. 


\subsection{O CENÁRIO ENERGÉTICO BRASILEIRO}

O cenário energético do Brasil está entre os mais sustentáveis do mundo, pois a matriz brasileira possui em sua composição $43,2 \%$ de renováveis, uma das porcentagens mais altas do mundo, conforme Figura 10.

Figura 10 - Composição de renováveis na matriz energética brasileira e mundo.

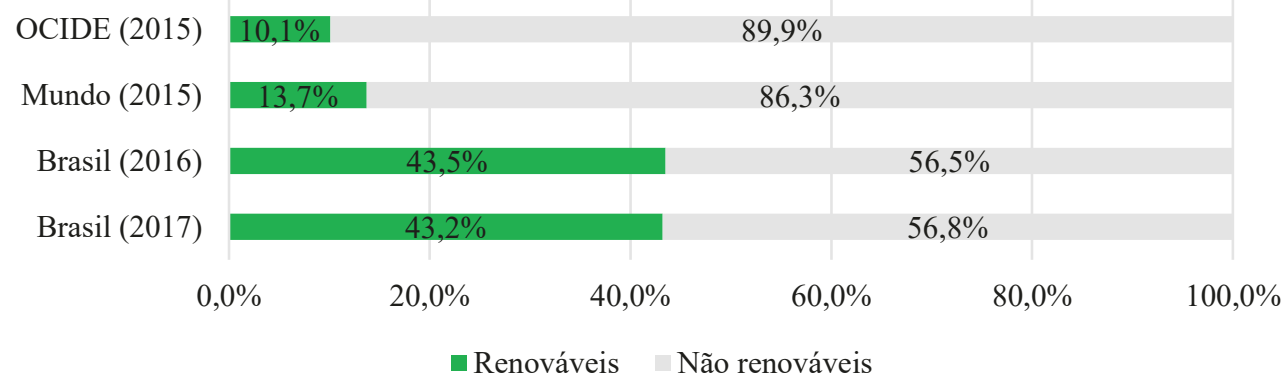

Fonte: EPE (2018).

Ao ampliar a análise da matriz energética brasileira e verificar a participação de recursos renováveis e não-renováveis na produção de energia elétrica, o Brasil pula para 80,4\% da sua composição baseada em renováveis, conforme Figura 11.

Figura 11 - Percentual de geração de energia elétrica por renováveis.

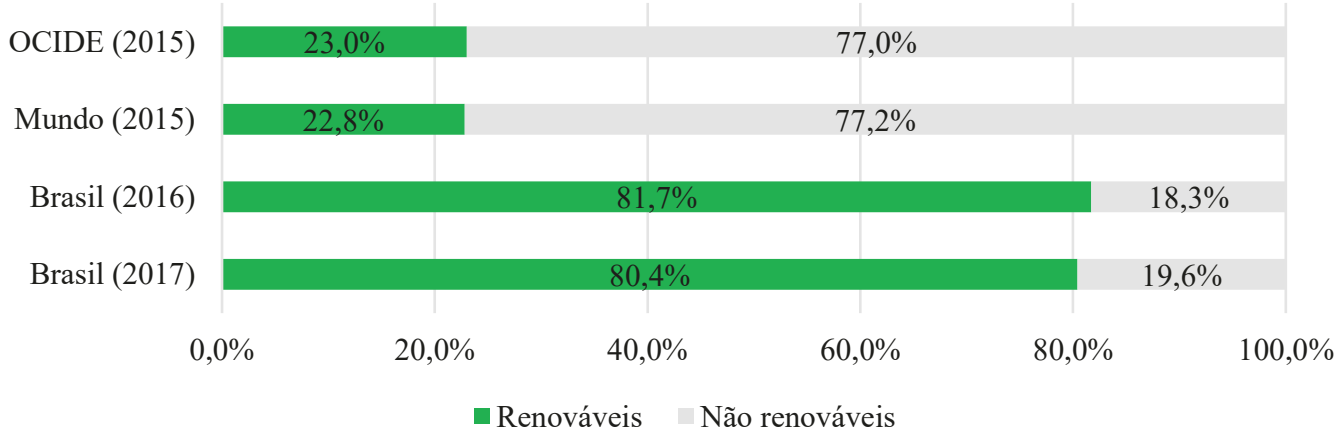

Fonte: EPE (2018). 
Para que se entenda melhor a importância da eletricidade como fonte de energia, se faz necessário interpretar mais detalhadamente a matriz individual desta fonte, que possui em sua composição $65,2 \%$ da sua produção gerada por meio da energia hidráulica, demonstrando a pressão atual do sistema sobre os recursos naturais renováveis e sobre os fatores climáticos, determinando que a sustentabilidade se faça presente como um objetivo intrínseco deste estudo no cenário brasileiro, o que pode ser comprovado pela Figura 12.

Figura 12 - Esquema comparativo de geração de eletricidade x consumo de eletricidade no Brasil.

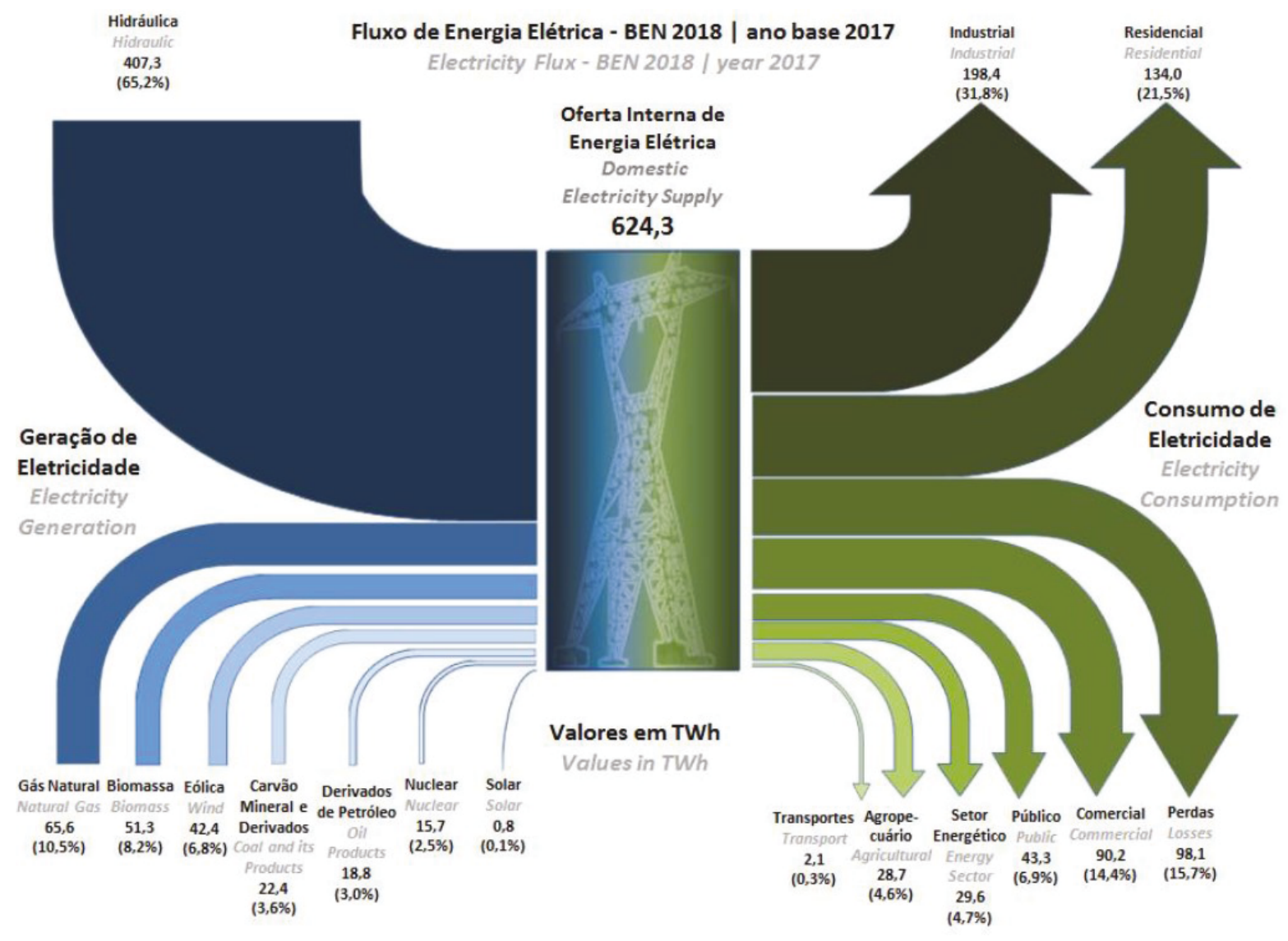

Fonte: EPE (2018).

De acordo com o EPE (2018), o setor industrial é o responsável pelo maior consumo de energia elétrica na matriz brasileira, respondendo por $31,8 \%$, seguido pelo setor residencial, com $21,5 \%$. Assim, nota-se que tanto há um espaço importante para estudos e pesquisas com o intuito de auxiliar na redução do consumo de energia, quanto para a aplicação de novas 
tecnologias e conceitos que atualmente são pouco explorados pelas empresas, conforme asseveram Chang et al. (2013).

A análise da matriz elétrica brasileira mostra uma elevada participação de fontes renováveis e tradicionalmente de menor custo, tais como as hidrelétricas (cerca de $65 \%$ da capacidade instalada). Entretanto, quase metade dessas usinas são as chamadas "a fio d'água", ou seja, não possuem grandes reservatórios de acumulação, o que deixa o sistema cada vez mais vulnerável à hidrologia. As chuvas abaixo da média histórica no biênio 2014/2015 agravaram ainda mais esse quadro, provocando a necessidade de intensificação do acionamento termelétrico. Com isso, sua participação passou de um patamar de 9\% em 2011 para mais de $25 \%$ em 2016. Tal situação elevou o preço da energia elétrica, uma vez que a geração termelétrica é mais cara. Compreende-se, dessa forma, que os preços no setor elétrico são extremamente suscetíveis às mudanças decorrentes de conjunturas adversas e que as escolhas referentes à composição da matriz intensificaram ainda mais essa condição. Aliado a isso, a política de "realismo tarifário" do governo trouxe um impacto real no custo médio, para a indústria, de 48,2\%, entre 2014 e 2016. Em julho de 2016, o valor da energia atingiu 504,00 $\mathrm{R} \$ / \mathrm{MWh}$, o que afetou diretamente os custos de produção das empresas (FIRJAN, 2017).

Esta discussão sobre os custos atuais de energia elétrica no Brasil, tal qual a variação de preços decorrente da imprevisibilidade dos fatores climáticos e da dependência da matriz atual, demandam entendimento sobre o sistema atual de tarifação de energia no Brasil.

\subsubsection{O sistema brasileiro de tarifação de energia}

A classificação tarifária no Brasil, de acordo com Eletrobras (2011), é composta por dois grupos, os quais são definidos, principalmente, em função do nível de tensão em que são atendidos e, por conseguinte, em função da demanda $(\mathrm{kW})$, a saber:

a) Grupo A: possui tarifa binômia e as unidades consumidoras são atendidas em alta tensão, acima de 2300 volts; destinado a indústrias, shopping centers e alguns edifícios comerciais;

b) Grupo B: possui tarifa monômia e as unidades consumidoras são atendidas em tensão abaixo de 2.300 volts; em geral, se enquadram neste grupo as residências, lojas, agências bancárias, pequenas oficinas, edifícios residenciais, grande parte dos edifícios 
comerciais e a maioria dos prédios públicos federais, uma vez que, em sua maioria são atendidos nas tensões de 127 ou 220 volts.

Os consumidores do Grupo A possuem alternativas para selecionar o enquadramento e valor contratual de demanda que possam resultar em menor despesa com energia elétrica. $\mathrm{O}$ Quadro 06 apresenta um resumo da composição tarifária das alternativas disponíveis aos consumidores do Grupo A:

Quadro 06 - Resumo das composições tarifárias.

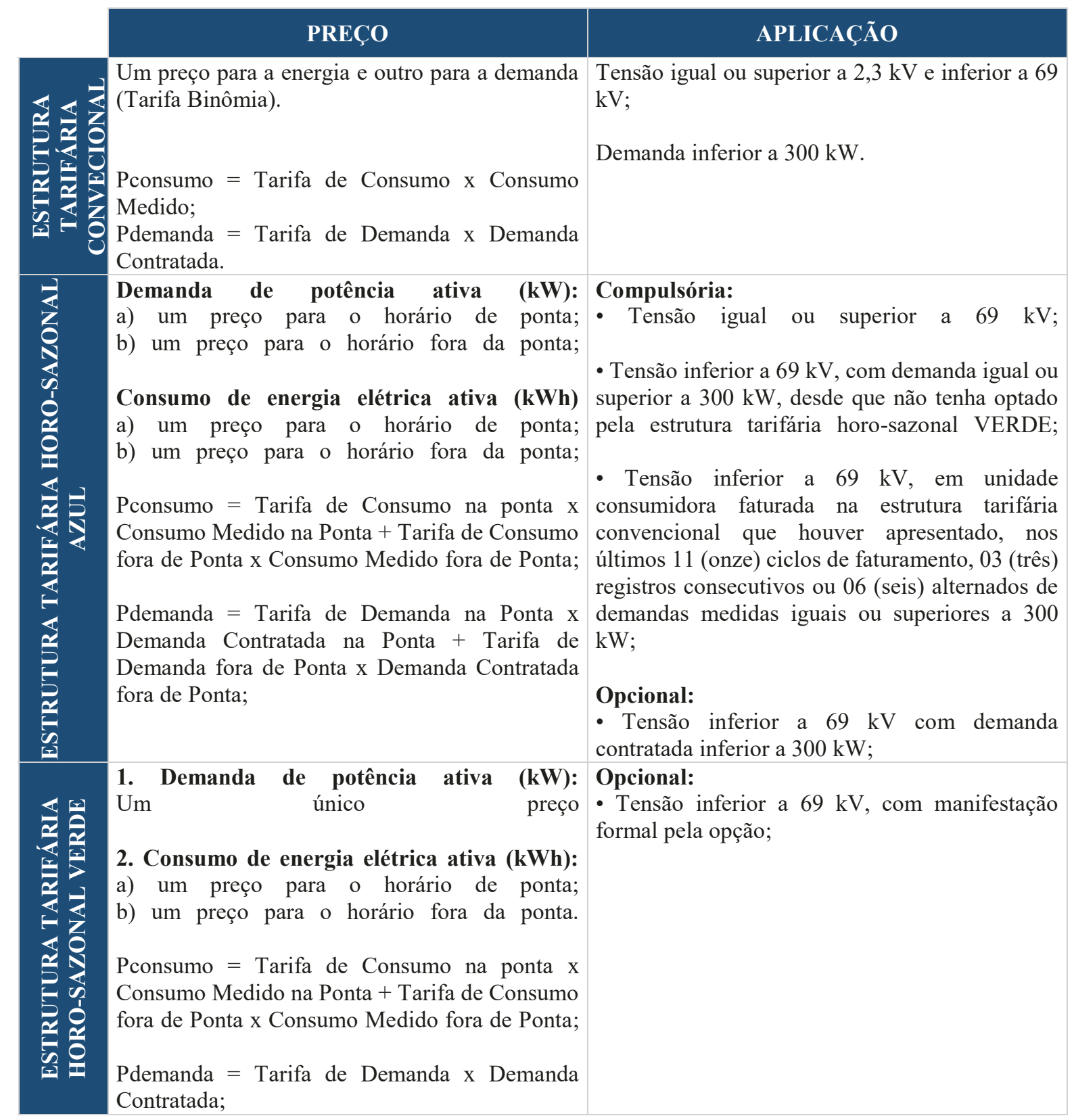

Fonte: Autor adaptado de Bandeirante Energia (2004). 
A Agência Nacional de Energia Elétrica, através da Resolução Normativa nº. 547, de maio de 2013, instituiu, a partir de $1^{\circ}$ de janeiro de 2015, no Brasil, o Sistema de Bandeiras Tarifárias (ANEEL, 2017). Este sistema reflete a variação do custo da geração de energia elétrica de acordo com o modelo utilizado e possui três classificações. Desta forma, com a adoção deste sistema, além do custo de geração da energia elétrica que é cobrado do consumidor cativo, há também um acréscimo referente às classificações das bandeiras tarifárias (AES ELETROPAULO, 2017). Uma visão geral deste sistema é apresentada no Quadro 07:

Quadro 07 - Sistema de bandeiras tarifárias.

\begin{tabular}{|c|c|c|}
\hline BANDEIRA & CONDIÇÕES & CUSTO \\
\hline Verde & $\begin{array}{l}\text { As condições hidrológicas para geração de } \\
\text { energia elétrica são favoráveis. }\end{array}$ & Não há qualquer acréscimo nas contas. \\
\hline Amarela & $\begin{array}{l}\text { As condições hidrológicas para geração de } \\
\text { energia elétrica são menos favoráveis. }\end{array}$ & $\begin{array}{l}\text { Há uma cobrança adicional, } \\
\text { proporcional ao consumo, na razão de } \\
\mathrm{R} \$ 1,00 \text { por } 100 \mathrm{kWh} .\end{array}$ \\
\hline $\begin{array}{l}\text { Vermelha } \\
\text { Patamar } 1\end{array}$ & $\begin{array}{l}\text { As condições hidrológicas para geração de } \\
\text { energia elétrica são mais desfavoráveis e } \\
\text { mais custosas. }\end{array}$ & $\begin{array}{l}\text { Há uma cobrança adicional, } \\
\text { proporcional ao consumo, na razão de } \\
\mathrm{R} \$ 3,00 \text { por } 100 \mathrm{kWh} .\end{array}$ \\
\hline $\begin{array}{l}\text { Vermelha } \\
\text { Patamar } 2\end{array}$ & $\begin{array}{l}\text { As condições hidrológicas para geração } \\
\text { de energia elétrica são ainda mais } \\
\text { desfavoráveis e mais custosas. }\end{array}$ & $\begin{array}{l}\text { Há uma cobrança adicional, } \\
\text { proporcional ao consumo, na razão de } \\
\mathrm{R} \$ 5,00 \text { por } 100 \mathrm{kWh} .\end{array}$ \\
\hline
\end{tabular}

Fonte: Autor adaptado de AES ELETROPAULO (2017).

O acionamento de cada bandeira tarifária é sinalizado mensalmente pela Agência Nacional de Energia Elétrica (ANEEL), de acordo com informações prestadas pelo Operador Nacional do Sistema (ONS), considerando-se a capacidade de geração de energia elétrica do país. A sinalização da bandeira a ser aplicada está diretamente associada ao acionamento de usinas térmicas e seus respectivos custos variáveis, sendo que todos os consumidores cativos das distribuidoras pagam o mesmo valor, proporcional ao seu consumo, independentemente de seu grupo tarifário (ANEEL, 2017).

Como já destacado, os preços no setor elétrico são extremamente suscetíveis às mudanças decorrentes de conjunturas adversas. As escolhas referentes à composição da matriz intensificam ainda mais essa condição. O que, conjugada à política de "realismo tarifário" do governo, trouxe um impacto real no custo médio para a indústria de $48,2 \%$ nos últimos três anos, conforme Figura 13 (FIRJAN, 2017). 
Figura 13 - Impacto do "realismo tarifário" do governo no custo de energia para a indústria.

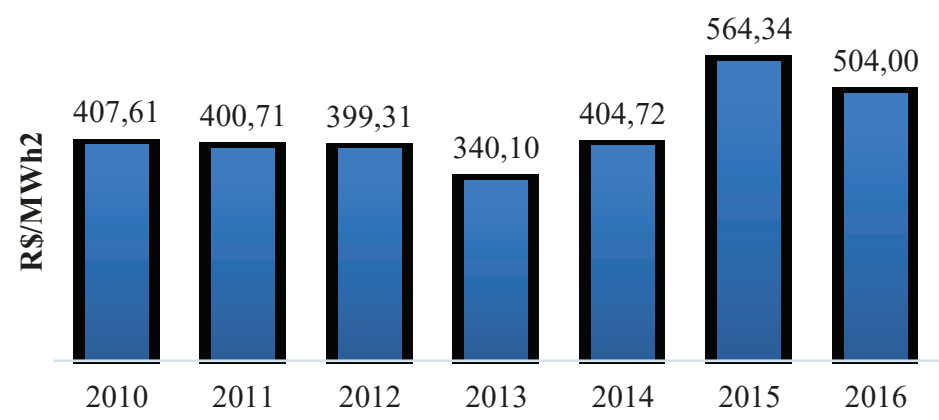

Fonte: FIRJAN (2017).

O custo médio da energia elétrica para a indústria no país, de 504,00 R \$/MWh, pode ser dividido em cinco componentes, de acordo com FIRJAN (2017), os quais são apresentados na Tabela 01:

Tabela 01 - Composição do custo médio da energia elétrica para a indústria no Brasil.

\begin{tabular}{|c|c|c|}
\hline COMPONENTE & R\$/MWh & $\mathbf{\%}$ \\
\hline $\begin{array}{c}\text { Geração, transmissão e } \\
\text { distribuição (GTD) }\end{array}$ & 298,45 & 59,2 \\
\hline Perdas & 36,95 & 7,3 \\
\hline Encargos & 23,98 & 4,8 \\
\hline Bandeiras & 8,75 & 1,7 \\
\hline Tributos & 135,87 & 27,0 \\
\hline TOTAL & $\mathbf{5 0 4 , 0 0}$ & $\mathbf{1 0 0 , 0}$ \\
\hline
\end{tabular}

Fonte: Autor adaptado de Sistema FIRJAN (2017).

Diante deste cenário, a aplicação de iniciativas de eficiência energética possui relevância para o cenário brasileiro, uma vez que os custos de energia podem variar de acordo com o cenário de bandeiras e por elevação de tributos e custos de geração e distribuição.

\subsection{BARREIRAS PARA A APLICAÇÃO DOS CONCEITOS DE EFICIÊNCIA ENERGÉTICA}

A eficiência energética vem ganhando relevância nas discussões acadêmicas e na indústria, especialmente, no que tange ao uso de tecnologias e novos conceitos. Apesar disso, diversas pesquisas apontam para um número elevado de barreiras presentes quanto a este tema, o que impacta diretamente na velocidade de adoração destas práticas, bem como nos resultados voltados à redução do consumo de energia elétrica. Brunke et al. (2014) apresentam, em sua 
pesquisa, as principais barreiras identificadas por diversos autores correlacionadas à eficiência energética.

De acordo com Wentemi, Apeaning e Thollander (2013), a falta de disponibilidade de orçamento, dificuldade de acesso a capital, assim como outras prioridades de investimentos, são fatores que estão presentes como barreiras em diversos segmentos de indústria.

Trianni et al. (2013), por sua vez, também apontam como fatores a falta de disponibilidade de orçamento e a dificuldade de acesso a capital para projetos de eficiência energética. Os autores indicam ainda que a falta de interesse em eficiência energética acompanhada da falta de clareza dos contratos de energia também são barreiras presentes nesta seara.

Estudiosos como Fleiter et al. (2012) e Shi et al. (2008) asseveram que o custo dos projetos de eficiência energética é, principalmente, no segmento de pequenas empresas (SME), um fator limitante. Outro aspecto relevante, de acordo com Groot et al. (2001), é a questão do custo efetivo da energia elétrica, que em alguns casos não é relevante a ponto de ser uma prioridade para as empresas.

Shi et al. (2008) e Dyer et al. (2008) relatam, em seus estudos, que, além dos fatores de capital, outras barreiras importantes são a falta de políticas de incentivo econômico voltadas à redução de energia e o baixo controle das autoridades sobre as ações de sustentabilidade. A dificuldade de se encontrarem colaboradores com as devidas competências para atuar neste segmento é apresentada como uma barreira por Anderson e Newell (2004) e Ren (2009).

Além dos aspectos já mencionados, a falta de comprometimento dos gestores das empresas aparece como um ponto relevante para a evolução deste tema. Brunke et al. (2014) apontam este fator como sendo um dos que possuem maior relevância para que se mude o cenário atual e se incentive o fomento a novas iniciativas nesta área.

No cenário nacional, Godoi (2011) e CNI (2009) corroboram o que já fora dito sobre as barreiras existentes no cenário mundial, destacando a falta de políticas públicas não pontuais, a falta de incentivos tributários, a falta de colaboradores com as devidas competências técnicas, o custo elevado de capital para investimento, a dificuldade de acesso a capital para investimento e o baixo conteúdo tecnológico na competitividade das empresas como fatores mais impactantes.

Isto posto, nota-se que os estudos voltados para a eficiência energética são altamente relevantes para remover as barreiras presentes nesta área, uma vez que os resultados discutidos e apresentados, em sua grande maioria, apresentam retornos expressivos e oportunidades até 
então pouco exploradas pelas empresas, o que poderá auxiliar no aumento da competitividade e, consequentemente, na redução dos custos operacionais. 


\section{ESCRIÇÃO DO SISTEMA DE MANUFATURA ABORDADO E PROCEDIMENTOS DO ESTUDO}

O sistema de manufatura analisado é um sistema de eventos discretos com processos de ciclos curtos, sendo uma das dezenas de linhas de produção de uma empresa multinacional brasileira que está entre as 3 maiores empresas do segmento no mundo. A empresa possui um modelo operacional orientado pela redução de custos, uma vez que possui um modelo de produção em massa para atender de forma global aos diversos mercados em que atua.

Mesmo com esta abordagem, a empresa ainda não realizou nenhum estudo relevante para identificar oportunidades com foco em eficiência energética. $\mathrm{O}$ custo de energia na área industrial representa um valor considerável (Quadro 08), sendo praticamente 20\% da sua folha de pagamentos.

Quadro 08 - Custo mensal de energia da empresa em estudo.

\begin{tabular}{|ccc}
\hline MÊS & $\begin{array}{c}\text { CUSTO MENSAL } \\
\text { (R\$) }\end{array}$ & BANDEIRA \\
\hline jan/17 & $536.696,95$ & Verde \\
\hline fev/17 & $621.189,99$ & Verde \\
\hline mar/17 & $810.618,25$ & Amarela \\
\hline abr/17 & $899.379,00$ & Vermelha P1 \\
\hline mai/17 & $699.718,20$ & Vermelha P1 \\
\hline jun/17 & $835.452,90$ & Verde \\
\hline jul/17 & $836.434,16$ & Amarela \\
\hline ago/17 & $909.457,56$ & Vermelha P1 \\
\hline set/17 & $1.131 .891,96$ & Amarela \\
\hline out/17 & $974.048,70$ & Vermelha P2 \\
\hline nov/17 & $971.885,00$ & Vermelha P2 \\
\hline dez/17 & $1.016 .043,68$ & Vermelha P1 \\
\hline jan/18 & $714.645,69$ & Verde \\
\hline fev/18 & $698.207,08$ & Verde \\
\hline mar/18 & $917.670,94$ & Verde \\
\hline abr/18 & $1.045 .594,59$ & Verde \\
\hline mai/18 & $1.032 .069,91$ & Amarela \\
\hline jun/18 & $1.079 .242,39$ & Vermelha P2 \\
\hline
\end{tabular}

Fonte: Autor (2018).

Para delimitar o estudo, as análises foram realizadas em uma das linhas de produção que é composta por 11 processos produtivos (Figura 14), que são estabelecidos por um sistema híbrido em que alguns processos possuem apenas um equipamento e outros operam com duas máquinas em paralelo. A empresa possui estoque em processo (buffers) com capacidade de 60.000 unidades após os processos: M2 Lavar e recozer, M4 Lavar, M7 Recozer e M8 
Espoletar. A utilização dos buffers tem como objetivo reduzir as perdas por paradas, porém não há estudo para definir a quantidade necessária.

Figura 14 - Fluxo de processos do sistema de manufatura em estudo.
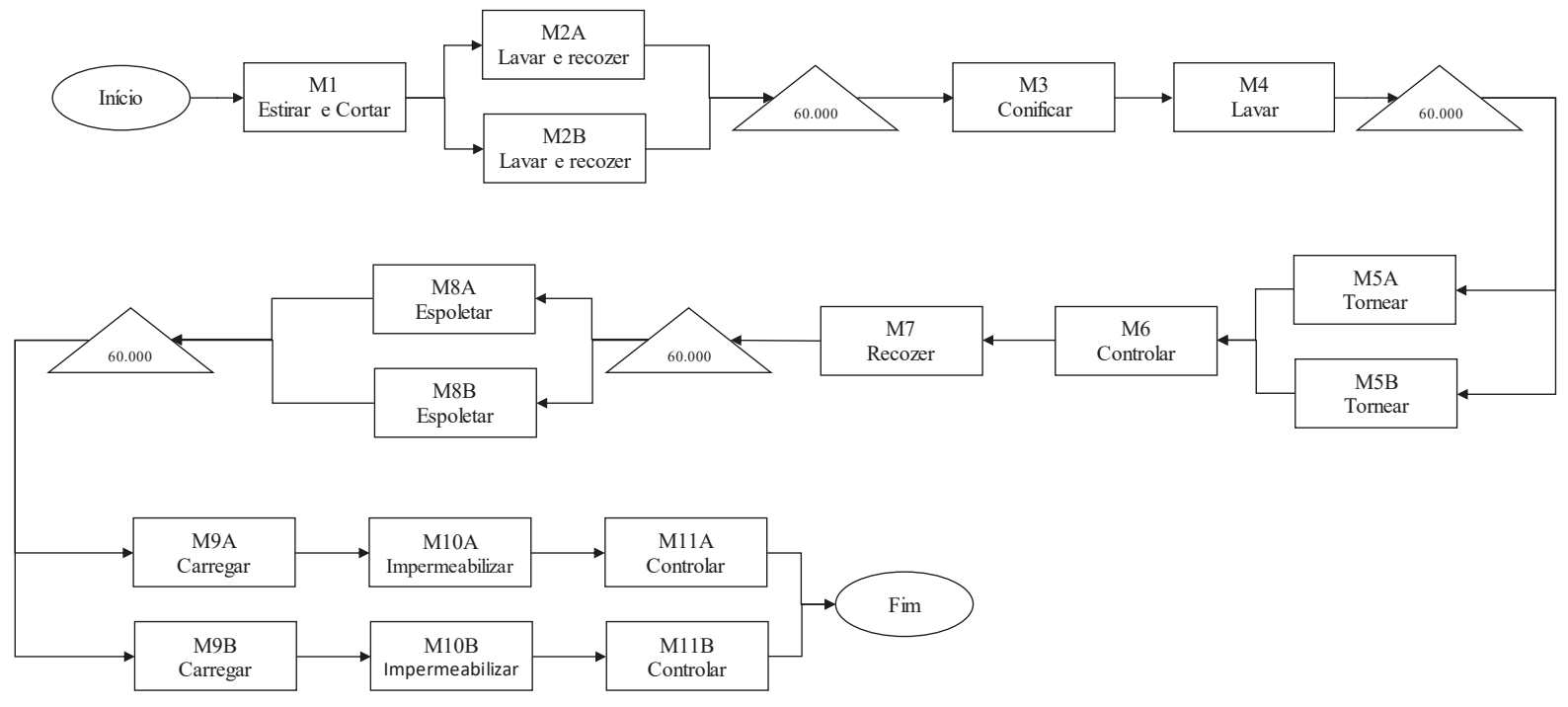

Fonte: Autor (2018).

Complementar ao processo produtivo, a Figura 15 apresenta o layout do sistema de manufatura. Percebe-se que o sistema de manufatura é uma linha de operações e montagem e, além disso, as operações estão alinhadas em fluxo da esquerda para a direita.

Figura 15 - Layout da linha de produção do estudo.
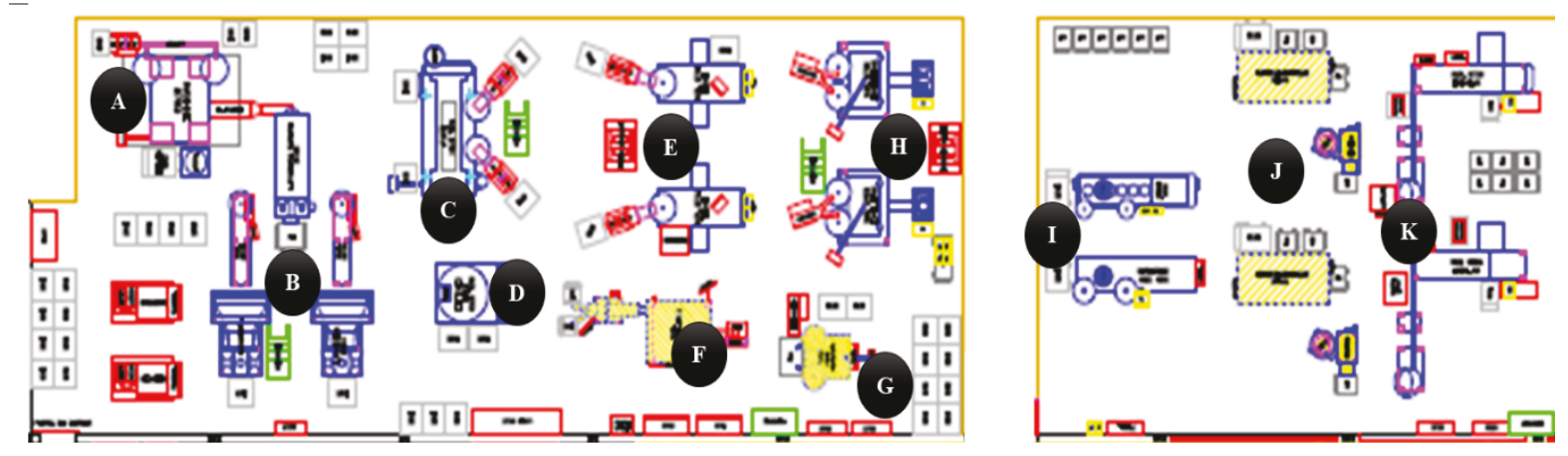

Fonte: Autor (2018).

Os processos foram identificados no layout de acordo com a lista abaixo:

a) M1 - Estirar e cortar;

b) M2 - Lavar e recozer;

c) M3-Conificar; 


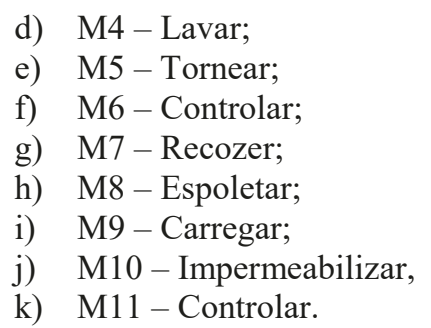

As estações de trabalho do sistema em análise possuem sistemas de alimentação automáticos que necessitam ser abastecidos em intervalos de tempo e de acordo com o consumo da estação para, desta forma, eliminar variáveis que não se remetam ao objetivo da análise. Considera-se que os operadores estarão sempre disponíveis para abastecer as estações de trabalho quando a estação necessitar e quando houver material disponível.

Todas as informações e parâmetros desta linha de produção foram levantados através da uma coleta de informações dos relatórios gerenciais da empresa e analisados estaticamente conforme o exemplo da estação M1 apresentado na Tabela 02. Para a realização dos estudos serão utilizadas as médias de cada parâmetro, obtidas na análise estatística.

Tabela 02 - Análise estatística dos dados básicos coletados para a estação M1.

\begin{tabular}{|c|c|c|c|c|c|}
\hline \multicolumn{6}{|c|}{ ESTAÇÃO M1 - ESTIRAR E CORTAR } \\
\hline \multicolumn{2}{|c|}{ Tempo de Ciclo (s) } & \multicolumn{2}{|c|}{ Dis ponibilidade (\%) } & \multicolumn{2}{|l|}{ MTTR (min) } \\
\hline Média & 0,286 & Média & 93,37 & Média & 52,98 \\
\hline Erro padrão & 0,000491304 & Erro padrão & 0,158553084 & Erro padrão & 0,368505213 \\
\hline Mediana & 0,286 & Mediana & 93,44 & Mediana & 52,955 \\
\hline Desvio padrão & 0,002690981 & Desvio padrão & 0,868431007 & Desvio padrão & 2,018386177 \\
\hline Variância da amostra & $7,24138 \mathrm{E}-06$ & Variância da amostra & 0,754172414 & Variância da amostra & 4,073882759 \\
\hline Curtose & $-0,09989202$ & Curtose & 0,505592935 & Curtose & 4,12501508 \\
\hline Assimetria & 0,159262147 & Assimetria & 0,229882352 & Assimetria & 0,903303968 \\
\hline Intervalo & 0,011 & Intervalo & 3,88 & Intervalo & 11,59 \\
\hline Mínimo & 0,281 & Mínimo & 91,56 & Mínimo & 48,25 \\
\hline Máximo & 0,292 & Máximo & 95,44 & Máximo & 59,84 \\
\hline Soma & 8,58 & Soma & 2801,1 & Soma & 1589,4 \\
\hline Contagem & 30 & Contagem & 30 & Contagem & 30 \\
\hline Nível de confiança $(95,0 \%)$ & 0,001004829 & Nível de confiança $(95,0 \%)$ & 0,324277467 & Nível de confiança $(95,0 \%)$ & 0,753677785 \\
\hline
\end{tabular}

Fonte: Autor (2018).

Os parâmetros apresentados incluem a quantidade de recursos de cada etapa do processo (único equipamento ou paralelo), o tempo de ciclo, a disponibilidade da estação de trabalho, o tempo médio de reparo (MTTR) e a capacidade do buffer entre os equipamentos (Tabela 03). Por ser uma linha de alto volume, a empresa opera em 3 turnos de trabalho (24h/dia), com paradas aos domingos. 
Tabela 03 - Parâmetros básicos de entrada para a simulação do modelo.

\begin{tabular}{|c|l|c|c|c|c|c|}
\hline Estação & \multicolumn{1}{|c|}{ Processo } & Recursos & $\begin{array}{c}\text { Tempo de } \\
\text { Ciclo (s) }\end{array}$ & $\begin{array}{c}\text { Disponibilidade } \\
\mathbf{( \% )}\end{array}$ & $\begin{array}{c}\text { MTTR } \\
(\mathbf{m i n})\end{array}$ & $\begin{array}{c}\text { Capacidade } \\
\text { Buffer } \\
\text { (Unidades) }\end{array}$ \\
\hline M1 & Estirar e cortar & 1 & 0,286 & 93,37 & 52,98 & - \\
\hline M2 & Lavar e recozer & 2 & 0,500 & 92,63 & 36,45 & 60.000 \\
\hline M3 & Conificar & 1 & 0,278 & 93,47 & 42,57 & - \\
\hline M4 & Lavar & 1 & 0,231 & 98,45 & 26,94 & - \\
\hline M5 & Tornear & 2 & 0,500 & 95,14 & 39,65 & 60.000 \\
\hline M6 & Controlar & 1 & 0,200 & 97,84 & 62,07 & - \\
\hline M7 & Recozer & 1 & 0,250 & 95,72 & 56,21 & 60.000 \\
\hline M8 & Espoletar & 2 & 0,500 & 96,19 & 43,52 & 60.000 \\
\hline M9 & Carregar & 2 & 0,500 & 95,38 & 51,85 & - \\
\hline M10 & Impermeabilizar & 2 & 0,500 & 97,14 & 29,71 & - \\
\hline M11 & Controlar & 2 & 0,500 & 96,85 & 46,37 & - \\
\hline
\end{tabular}

Fonte: Autor (2018).

A disponibilidade da estação de trabalho foi levantada através dos dados dos indicadores de produção e paradas de linha da empresa. Este dado contempla apenas as paradas por falha no equipamento e ajustes. A empresa utiliza o conceito de eficiência por célula, medido através dos volumes produzidos versus a capacidade total.

Para a correta avaliação do estudo entre as relações de produtividade e efíciência energética, os estados possíveis de energia das estações de trabalho foram levantados juntos aos técnicos eletrônicos da empresa, bem como a devida potência elétrica em cada estado (consumo de energia).

Para estabelecer um padrão conceitual, será considerada, neste estudo, a proposta de May et al. (2015), que propõe os seguintes estados de energia para os equipamentos de manufatura: desligado, em desenergização, standby, manutenção, operacional, setup, em energização e processamento.

É fundamental que se considere que o sistema de manufatura em análise possui equipamentos com tempo médio de 15 anos em operação e, desta forma, alguns estados de energia não estão parametrizados nos equipamentos, o que dificulta sua identificação, mas abre uma lacuna de oportunidade para explorar o objetivo deste trabalho.

Como os tempos de ciclos são em média 0,5 segundos por peça, o tempo de transição dos estados de energia disponíveis nos equipamentos são praticamente nulos e, desta forma, este dado não será utilizado no estudo. A Tabela 04 apresenta todos os dados de consumo de energia relevantes para o estudo e que foram passíveis de levantamento pela empresa. 
Tabela 04 - Parâmetros básicos de entrada para a simulação de energia.

\begin{tabular}{|c|l|c|c|c|c|}
\hline \multirow{2}{*}{ Estação } & \multirow{2}{*}{ Processo } & \multicolumn{4}{|c|}{ Consumo por estado de energia (kWh) } \\
\cline { 3 - 6 } & & Processamento & Operacional & Manutenção & Standby \\
\hline M1 & Estirar e cortar & 21,53 & 8,61 & 8,61 & 2,15 \\
\hline M2 & Lavar e recozer & 46,57 & 18,63 & 18,63 & 4,66 \\
\hline M3 & Conificar & 16,00 & 6,40 & 6,40 & 1,60 \\
\hline M4 & Lavar & 8,55 & 3,42 & 3,42 & 0,86 \\
\hline M5 & Tornear & 5,98 & 2,39 & 2,39 & 0,60 \\
\hline M6 & Controlar & 3,33 & 1,33 & 1,33 & 0,33 \\
\hline M7 & Recozer & 18,21 & 7,29 & 7,29 & 1,82 \\
\hline M8 & Espoletar & 4,42 & 1,77 & 1,77 & 0,44 \\
\hline M9 & Carregar & 3,73 & 1,49 & 1,49 & 0,37 \\
\hline M10 & Impermeabilizar & 2,10 & 0,84 & 0,84 & 0,21 \\
\hline M11 & Controlar & 1,83 & 0,73 & 0,73 & 0,18 \\
\hline
\end{tabular}

Fonte: Autor (2018).

\subsection{PROCEDIMENTO DE ESTUDO}

Para facilitar a análise do sistema através do software de simulação, a aplicação dos conceitos e regras de programação foram realizados de forma incremental através da construção de cenários distintos. Desta forma, foi possível avaliar isoladamente as variáveis e identificar em cada cenário os pontos positivos que contribuem com a eficiência enérgica e outras oportunidades para o modelo. Deste modo, a proposta de abordagem do plano de projeto foi construída em quatro etapas (cenários), conforme a Quadro 09. 
Quadro 09 - Descritivo dos cenários em estudo.

\begin{tabular}{|c|c|c|c|c|}
\hline & $\mathbf{A}$ & B & $\mathbf{C}$ & D \\
\hline CENÁRIO & $\begin{array}{l}\text { Sem ocorrência de } \\
\text { paradas não- } \\
\text { planejadas aleatórias. }\end{array}$ & $\begin{array}{l}\text { Com ocorrência de } \\
\text { paradas não- } \\
\text { planejadas aleatórias. }\end{array}$ & $\begin{array}{l}\text { Com ocorrência de } \\
\text { paradas não-planejadas } \\
\text { aleatórias e gerenciamento } \\
\text { do estado de máquina em } \\
\text { função da quantidade de } \\
\text { peças dos buffers e do } \\
\text { sistema de alimentação de } \\
\text { cada estação de trabalho. }\end{array}$ & $\begin{array}{l}\text { Com gerenciamento do } \\
\text { estado de máquina em } \\
\text { função da quantidade de } \\
\text { peças dos buffers e do } \\
\text { sistema de alimentação de } \\
\text { cada estação de trabalho e } \\
\text { paradas planejadas diárias } \\
\text { de manutenção. }\end{array}$ \\
\hline OBJETIVO & $\begin{array}{l}\text { Identificar a máxima } \\
\text { produtividade do } \\
\text { sistema em condições } \\
\text { ideais. }\end{array}$ & $\begin{array}{l}\text { Analisar o sistema em } \\
\text { estudo e identificar o } \\
\text { consumo energético e } \\
\text { a produtividade atual. }\end{array}$ & $\begin{array}{l}\text { Analisar o impacto no } \\
\text { consumo energético } \\
\text { através do controle de } \\
\text { estado de máquina pelo } \\
\text { nível dos buffers } \\
\text { intermediários e dos } \\
\text { sistemas de alimentação } \\
\text { para sistemas de } \\
\text { manufatura com processos } \\
\text { de ciclos curtos. }\end{array}$ & $\begin{array}{l}\text { Analisar o impacto no } \\
\text { consumo energético } \\
\text { através do controle de } \\
\text { estado de máquina pelo } \\
\text { nível dos buffers } \\
\text { intermediários, dos } \\
\text { sistemas de alimentação e } \\
\text { do planejamento das } \\
\text { paradas diárias de } \\
\text { manutenção para sistemas } \\
\text { de manufatura com } \\
\text { processos de ciclos curtos. }\end{array}$ \\
\hline KPI & \multicolumn{4}{|c|}{ Volume de Produção e Eficiência Energética (Lean Energy Indicator e Energia consumida por peça) } \\
\hline $\begin{array}{l}\text { ESTADOS DE } \\
\text { MÁQUINA }\end{array}$ & $\begin{array}{l}\text { Processamento } \\
\text { (Working); } \\
\text { Operacional } \\
\text { (Operational). }\end{array}$ & $\begin{array}{l}\text { Processamento } \\
\text { (Working); } \\
\text { Operacional } \\
\text { (Operational); } \\
\text { Manutenção } \\
\text { (Failed). }\end{array}$ & $\begin{array}{r}\text { Processament } \\
\text { Operacional }(( \\
\text { Manutençã } \\
\text { Stanc } \\
\text { Desenergiz }\end{array}$ & $\begin{array}{l}\text { to (Working); } \\
\text { Operational); } \\
\text { lo (Failed }) \text {; } \\
\text { dby; } \\
\text { zado }(\text { Off }) \text {. }\end{array}$ \\
\hline $\begin{array}{l}\text { REGRAS DE } \\
\text { PROGRAMAÇÃO }\end{array}$ & \multicolumn{2}{|c|}{ Não há } & $\begin{array}{l}\text { - Controle do estado de } \\
\text { máquina em função } \\
\text { da quantidade de } \\
\text { peças no sistema de } \\
\text { alimentação } \\
\text { buffers. }\end{array}$ & $\begin{array}{l}\text { - Controle do estado de } \\
\text { máquina em função } \\
\text { da quantidade de } \\
\text { peças no sistema de } \\
\text { alimentação } \\
\text { buffers. } \\
\text { Planejamento das } \\
\text { paradas de } \\
\text { manutenção. }\end{array}$ \\
\hline
\end{tabular}

Fonte: Autor (2018).

\subsection{DETALHAMENTO E PARÂMETROS DOS CENÁRIOS}

\subsubsection{Cenário A}

Sistema de manufatura sem ocorrências de paradas não-planejadas, com a utilização de buffers após as estações M2, M4, M7 e M8 e equipamentos assumindo apenas os estados de energia "operacional” e "processamento". Este cenário visa analisar os indicadores de energia 
elétrica e produtividade em um sistema de manufatura com processos de ciclos curtos em uma situação sem distúrbios aleatórios e com restrições de tempo de ciclo entre as estações de trabalho.

Tabela 05 - Parâmetros básicos para a simulação do modelo referente ao cenário A.

\begin{tabular}{|c|c|c|c|c|c|c|}
\hline Estação & Processo & Recursos & $\begin{array}{l}\text { Tempo de } \\
\text { Ciclo (s) }\end{array}$ & $\begin{array}{c}\text { Disponibilidade } \\
(\%)\end{array}$ & MTTR (min) & $\begin{array}{c}\text { Capacidade } \\
\text { Buffer } \\
\text { (Unidades) }\end{array}$ \\
\hline M1 & Estirar e cortar & 1 & 0,286 & 100 & NA & - \\
\hline M2 & Lavar e recozer & 2 & 0,500 & 100 & NA & 60.000 \\
\hline M3 & Conificar & 1 & 0,278 & 100 & NA & - \\
\hline M4 & Lavar & 1 & 0,231 & 100 & NA & - \\
\hline M5 & Tornear & 2 & 0,500 & 100 & NA & 60.000 \\
\hline M6 & Controlar & 1 & 0,200 & 100 & NA & - \\
\hline M7 & Recozer & 1 & 0,250 & 100 & NA & 60.000 \\
\hline M8 & Espoletar & 2 & 0,500 & 100 & NA & 60.000 \\
\hline M9 & Carregar & 2 & 0,500 & 100 & NA & - \\
\hline M10 & Impermeabilizar & 2 & 0,500 & 100 & NA & - \\
\hline M11 & Controlar & 2 & 0,500 & 100 & NA & - \\
\hline
\end{tabular}

Fonte: Autor (2018).

Tabela 06 - Parâmetros básicos para a simulação de energia referente ao cenário A.

\begin{tabular}{|c|l|c|c|c|c|}
\hline \multirow{2}{*}{ Estação } & \multirow{2}{*}{ Processo } & \multicolumn{3}{|c|}{ Consumo por estado de energia (kWh) } \\
\cline { 2 - 6 } & Processamento & Operacional & Manutenção & Standby \\
\hline M1 & Estirar e cortar & 21,53 & 8,61 & NA & NA \\
\hline M2 & Lavar e recozer & 46,57 & 18,63 & NA & NA \\
\hline M3 & Conificar & 16,00 & 6,40 & NA & NA \\
\hline M4 & Lavar & 8,55 & 3,42 & NA & NA \\
\hline M5 & Tornear & 5,98 & 2,39 & NA & NA \\
\hline M6 & Controlar & 3,33 & 1,33 & NA & NA \\
\hline M7 & Recozer & 18,21 & 7,29 & NA & NA \\
\hline M8 & Espoletar & 4,42 & 1,77 & NA & NA \\
\hline M9 & Carregar & 3,73 & 1,49 & NA & NA \\
\hline M10 & Impermeabilizar & 2,10 & 0,84 & NA & NA \\
\hline M11 & Controlar & 1,83 & 0,73 & NA & NA \\
\hline
\end{tabular}

Fonte: Autor (2018).

\subsubsection{Cenário $B$}

Sistema de manufatura com ocorrência de paradas não-planejadas aleatórias, com a utilização de buffers após as estações M2, M4, M7 e M8 e equipamentos assumindo apenas os estados de energia "operacional", "processamento" e "manutenção". Este cenário visa analisar os indicadores de energia elétrica e produtividade em um sistema de manufatura com processos 
de ciclos curtos, o qual possui o sincronismo afetado devido à ocorrência de eventos não previstos de paradas individuais das máquinas.

Tabela 07 - Parâmetros básicos para a simulação do modelo referente ao cenário B.

\begin{tabular}{|c|l|c|c|c|c|c|}
\hline Estação & \multicolumn{1}{|c|}{ Processo } & Recursos & $\begin{array}{c}\text { Tempo de } \\
\text { Ciclo (s) }\end{array}$ & $\begin{array}{c}\text { Disponibilidade } \\
\mathbf{( \% )}\end{array}$ & $\begin{array}{c}\text { MTTR } \\
\text { (min) }\end{array}$ & $\begin{array}{c}\text { Capacidade } \\
\text { Buffer } \\
\text { (Unidades) }\end{array}$ \\
\hline M1 & Estirar e cortar & 1 & 0,286 & 93,37 & 52,98 & - \\
\hline M2 & Lavar e recozer & 2 & 0,500 & 92,63 & 36,45 & 60.000 \\
\hline M3 & Conificar & 1 & 0,278 & 93,47 & 42,57 & - \\
\hline M4 & Lavar & 1 & 0,231 & 98,45 & 26,94 & - \\
\hline M5 & Tornear & 2 & 0,500 & 95,14 & 39,65 & 60.000 \\
\hline M6 & Controlar & 1 & 0,200 & 97,84 & 62,07 & - \\
\hline M7 & Recozer & 1 & 0,250 & 95,72 & 56,21 & 60.000 \\
\hline M9 & Espoletar & 2 & 0,500 & 96,19 & 43,52 & 60.000 \\
\hline M10 & Impermeabilizar & 2 & 0,500 & 95,38 & 51,85 & - \\
\hline M11 & Controlar & 2 & 0,500 & 96,85 & 46,37 & - \\
\hline
\end{tabular}

Fonte: Autor (2018).

Tabela 08 - Parâmetros básicos para a simulação de energia referente ao cenário B.

\begin{tabular}{|c|l|c|c|c|c|}
\hline \multirow{2}{*}{ Estação } & \multirow{2}{*}{ Processo } & \multicolumn{4}{|c|}{ Consumo por estado de energia (kWh) } \\
\cline { 3 - 6 } & & Processamento & Operacional & Manutenção & Standby \\
\hline M1 & Estirar e cortar & 21,53 & 8,61 & 8,61 & NA \\
\hline M2 & Lavar e recozer & 46,57 & 18,63 & 18,63 & NA \\
\hline M3 & Conificar & 16,00 & 6,40 & 6,40 & NA \\
\hline M4 & Lavar & 8,55 & 3,42 & 3,42 & NA \\
\hline M5 & Tornear & 5,98 & 2,39 & 2,39 & NA \\
\hline M6 & Controlar & 3,33 & 1,33 & 1,33 & NA \\
\hline M7 & Recozer & 18,21 & 7,29 & 7,29 & NA \\
\hline M8 & Espoletar & 4,42 & 1,77 & 1,77 & NA \\
\hline M9 & Carregar & 3,73 & 1,49 & 1,49 & NA \\
\hline M10 & Impermeabilizar & 2,10 & 0,84 & 0,84 & NA \\
\hline M11 & Controlar & 1,83 & 0,73 & 0,73 & NA \\
\hline
\end{tabular}

Fonte: Autor (2018).

\subsubsection{Cenário $\mathrm{C}$}

Sistema de manufatura com ocorrência de paradas não-planejadas aleatórias, com gerenciamento do estado de máquina em função da quantidade de peças dos buffers após as estações M2, M4, M7 e M8 e do sistema de alimentação de cada estação de trabalho, tendo como foco melhorar o consumo de energia e avaliar o impacto na produtividade. Equipamentos assumindo os estados de energia "operacional”, "processamento", "manutenção", "standby" e 
“desenergizado". Este cenário visa analisar os indicadores de energia elétrica e produtividade em um sistema de manufatura com processos de ciclos curtos, a qual possui o sincronismo afetado devido à ocorrência de eventos não previstos de paradas individuais das máquinas, mas minimizados pelas regras de programação de gerenciamento dos estados de máquinas dos equipamentos através do controle de unidades presentes nos buffers e sistemas de alimentação.

Tabela 09 - Parâmetros básicos para a simulação do modelo referente ao cenário C.

\begin{tabular}{|c|c|c|c|c|c|c|}
\hline Estação & Processo & Recursos & $\begin{array}{l}\text { Tempo de } \\
\text { Ciclo (s) }\end{array}$ & $\begin{array}{c}\text { Disponibilidade } \\
(\%)\end{array}$ & $\begin{array}{l}\text { MTTR } \\
\text { (min) }\end{array}$ & $\begin{array}{c}\text { Capacidade } \\
\text { Buffer } \\
\text { (Unidades) }\end{array}$ \\
\hline M1 & Estirar e cortar & 1 & 0,286 & 93,37 & 52,98 & - \\
\hline M2 & Lavar e recozer & 2 & 0,500 & 92,63 & 36,45 & 60.000 \\
\hline M3 & Conificar & 1 & 0,278 & 93,47 & 42,57 & - \\
\hline M4 & Lavar & 1 & 0,231 & 98,45 & 26,94 & - \\
\hline M5 & Tornear & 2 & 0,500 & 95,14 & 39,65 & 60.000 \\
\hline M6 & Controlar & 1 & 0,200 & 97,84 & 62,07 & - \\
\hline M7 & Recozer & 1 & 0,250 & 95,72 & 56,21 & 60.000 \\
\hline M8 & Espoletar & 2 & 0,500 & 96,19 & 43,52 & 60.000 \\
\hline M9 & Carregar & 2 & 0,500 & 95,38 & 51,85 & - \\
\hline M10 & Impermeabilizar & 2 & 0,500 & 97,14 & 29,71 & - \\
\hline M11 & Controlar & 2 & 0,500 & 96,85 & 46,37 & - \\
\hline
\end{tabular}

Fonte: Autor (2018).

Tabela 10 - Parâmetros básicos para a simulação de energia referente ao cenário C.

\begin{tabular}{|c|l|c|c|c|c|}
\hline \multirow{2}{*}{ Estação } & \multirow{2}{*}{ Processo } & \multicolumn{4}{|c|}{ Consumo por estado de energia (kWh) } \\
\cline { 3 - 6 } & & Processamento & Operacional & Manutenção & Standby \\
\hline M1 & Estirar e cortar & 21,53 & 8,61 & 8,61 & 2,15 \\
\hline M2 & Lavar e recozer & 46,57 & 18,63 & 18,63 & 4,66 \\
\hline M3 & Conificar & 16,00 & 6,40 & 6,40 & 1,60 \\
\hline M4 & Lavar & 8,55 & 3,42 & 3,42 & 0,86 \\
\hline M5 & Tornear & 5,98 & 2,39 & 2,39 & 0,60 \\
\hline M6 & Controlar & 3,33 & 1,33 & 1,33 & 0,33 \\
\hline M7 & Recozer & 18,21 & 7,29 & 7,29 & 1,82 \\
\hline M8 & Espoletar & 4,42 & 1,77 & 1,77 & 0,44 \\
\hline M9 & Carregar & 3,73 & 1,49 & 1,49 & 0,37 \\
\hline M10 & Impermeabilizar & 2,10 & 0,84 & 0,84 & 0,21 \\
\hline M11 & Controlar & 1,83 & 0,73 & 0,73 & 0,18 \\
\hline
\end{tabular}

Fonte: Autor (2018).

\subsubsection{Cenário D}

Sistema de manufatura com ocorrência de paradas planejadas diárias de manutenção, com gerenciamento do estado de máquina em função da quantidade de peças dos buffers após as estações M2, M4, M7 e M8 e do sistema de alimentação de cada estação de trabalho, com foco em melhorar o consumo de energia, bem como avaliar o impacto na produtividade. 
Equipamentos assumindo os estados de energia "operacional", "processamento", "manutenção", "standby" e "desenergizado". Este cenário visa analisar os indicadores de energia elétrica e produtividade em um sistema de manufatura com processos de ciclos curtos, porém, com a adição de manutenção preventivas diárias de todos os equipamentos do processo, eliminando assim as ocorrências de paradas não planejadas, além disso, o cenário utiliza das regras de programação de gerenciamento dos estados de máquinas dos equipamentos através do controle de unidades presentes nos buffers e sistemas de alimentação.

Tabela 11 - Parâmetros básicos para a simulação do modelo referente ao cenário D.

\begin{tabular}{|c|c|c|c|c|c|c|c|}
\hline \multirow{2}{*}{ Estação } & \multirow{2}{*}{ Processo } & \multirow{2}{*}{ Recursos } & \multirow{2}{*}{$\begin{array}{l}\text { Tempo de } \\
\text { Ciclo (s) }\end{array}$} & \multicolumn{3}{|c|}{$\begin{array}{c}\text { Paradas Planejadas de Manutenção e } \\
\text { Ajustes }\end{array}$} & \multirow{2}{*}{$\begin{array}{c}\text { Capacidade } \\
\text { Buffer } \\
\text { (Unidades) }\end{array}$} \\
\hline & & & & $\begin{array}{c}\text { Início } \\
\text { (hh:mm:ss) }\end{array}$ & Duração (min) & $\begin{array}{l}\text { Intervalo } \\
\text { (hh:mm:ss) }\end{array}$ & \\
\hline M1 & Estirar e cortar & 1 & 0,286 & $20: 00: 00$ & \multirow{11}{*}{60} & \multirow{11}{*}{ 23:00:00 } & - \\
\hline M2 & Lavar e recozer & 2 & 0,500 & 20:00:00 & & & 60.000 \\
\hline M3 & Conificar & 1 & 0,278 & 19:00:00 & & & - \\
\hline M4 & Lavar & 1 & 0,231 & 19:00:00 & & & - \\
\hline M5 & Tornear & 2 & 0,500 & 18:00:00 & & & 60.000 \\
\hline M6 & Controlar & 1 & 0,200 & 18:00:00 & & & - \\
\hline M7 & Recozer & 1 & 0,250 & 18:00:00 & & & 60.000 \\
\hline M8 & Espoletar & 2 & 0,500 & $17: 00: 00$ & & & 60.000 \\
\hline M9 & Carregar & 2 & 0,500 & 16:00:00 & & & - \\
\hline M10 & Impermeabilizar & 2 & 0,500 & $16: 00: 00$ & & & - \\
\hline M11 & Controlar & 2 & 0,500 & $16: 00: 00$ & & & - \\
\hline
\end{tabular}

Fonte: Autor (2018).

Tabela 12 - Parâmetros básicos para a simulação de energia referente ao cenário D.

\begin{tabular}{|c|l|c|c|c|c|}
\hline \multirow{2}{*}{ Estação } & \multirow{2}{*}{ Processo } & \multicolumn{4}{|c|}{ Consumo por estado de energia (kWh) } \\
\cline { 3 - 6 } & & Processamento & Operacional & Manutenção & Standby \\
\hline M1 & Estirar e cortar & 21,53 & 8,61 & 8,61 & 2,15 \\
\hline M2 & Lavar e recozer & 46,57 & 18,63 & 18,63 & 4,66 \\
\hline M3 & Conificar & 16,00 & 6,40 & 6,40 & 1,60 \\
\hline M4 & Lavar & 8,55 & 3,42 & 3,42 & 0,86 \\
\hline M5 & Tornear & 5,98 & 2,39 & 2,39 & 0,60 \\
\hline M6 & Controlar & 3,33 & 1,33 & 1,33 & 0,33 \\
\hline M7 & Recozer & 18,21 & 7,29 & 7,29 & 1,82 \\
\hline M8 & Espoletar & 4,42 & 1,77 & 1,77 & 0,44 \\
\hline M9 & Carregar & 3,73 & 1,49 & 1,49 & 0,37 \\
\hline M10 & Impermeabilizar & 2,10 & 0,84 & 0,84 & 0,21 \\
\hline M11 & Controlar & 1,83 & 0,73 & 0,73 & 0,18 \\
\hline
\end{tabular}

Fonte: Autor (2018). 


\subsubsection{Modelagem}

Os cenários foram desenvolvidos através dos dados apresentados nas tabelas de parâmetros referentes a cada cenário e pela modelagem de regras de programação, que foram desenvolvidas através da aplicação de métodos em diversas etapas do modelo. Essa programação se fez necessária uma vez que o software não realiza de forma padrão os gerenciamentos de energia necessários para a realização deste estudo, o que amplifica a complexidade do modelo e por consequência a oportunidade para obter resultados diferentes dos modelos convencionais.

O quadro 10 apresenta de forma resumida as informações do modelo e suas características em cada cenário. Desta forma pode-se entender o fluxo de processo e a aplicação das regras de programação em cada uma das estações, bem como a necessidade do uso dos buffers para gerenciar o momento de ativação e utilização das regras para que se possa melhorar o consumo de energia no sistema de manufatura. 
Quadro 10 - Diagrama de processo e parâmetros de modelagem.

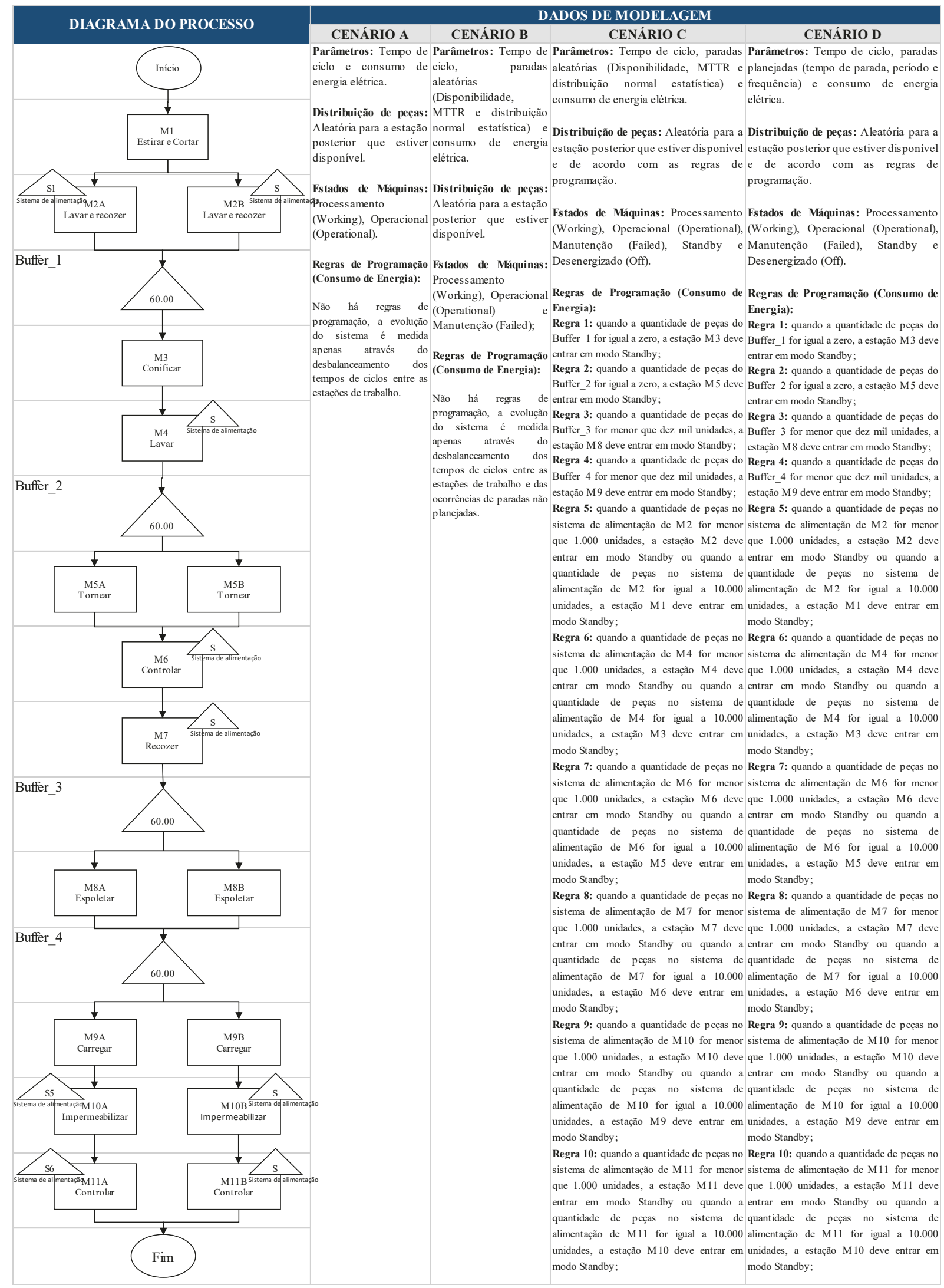

Fonte: Autor (2018). 


\section{IMPLEMENTAÇÃO DOS MODELOS E AVALIAÇÃO DE RESULTADOS}

Os cenários propostos representam opções distintas de situações operacionais, o que possibilita uma avaliação das oportunidades com base nas diferenças de cada cenário. As simulações foram padronizadas pelo período de 2.880 minutos (2 dias) e a apresentação dos resultados fora realizada através de quatro tópicos: modelo e dados, produtividade, consumo energético e avaliação geral dos resultados.

a) Modelos e dados: apresentação dos modelos de cada cenário e dos dados extraídos do software de simulação;

b) Produtividade: avaliação da produtividade em cada cenário;

c) Consumo energético: avaliação da eficiência energética em cada cenário,

d) Avaliação geral dos resultados: discussão geral dos resultados obtidos em cada um dos cenários em virtude das regras de programação utilizadas.

As análises têm com foco avaliar os conceitos apresentados referente a eficiência energética através da simulação dos modelos e identificar se as regras de programações apresentadas possuem relevância para sistemas de manufatura com processos de ciclos curtos.

\subsection{MODELOS E DADOS}

\subsubsection{Cenário A}

O cenário avaliado representa a situação ideal da linha de produção em estudo, uma vez que não há ocorrências de paradas não-planejadas. Além disso, as linhas trabalham de modo sincronizado, o que possibilita uma saída de produção com melhores indicadores. O modelo abaixo representa a distribuição do sistema de manufatura e pode ser avaliado na Figura 16. Após as estações M2, M4, M7 e M8, o sistema utiliza buffers com capacidade máxima de 60.000 peças, sendo que o Buffer_3 e Buffer_4 devem iniciar a simulação com 10.000 unidades devido aos parâmetros de qualidade do produto. Desta forma, o cenário inicia com a quantidade de 10.000 unidades em cada um destes buffers, porém, não há controles de estados de máquinas a partir da quantidade de peças nos buffers. 
Figura 16 - Ilustração do modelo de simulação do cenário A.

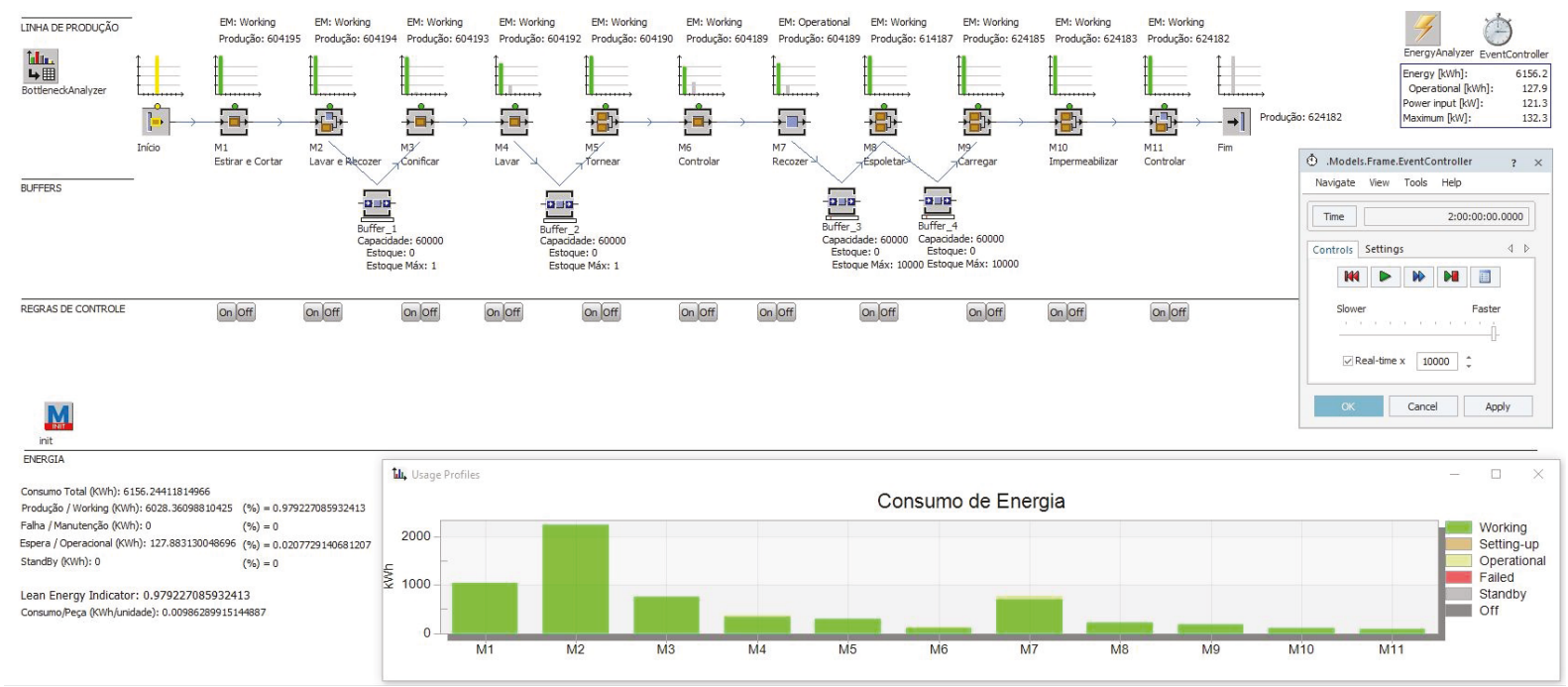

Fonte: Autor (2018).

Os dados de cada estação foram estratificados e apresentados em tópicos. A Tabela 13 apresenta os dados de produtividade. A Tabela 14 apresenta os valores absolutos de consumo individual de energia nos diferentes estados de máquina de cada equipamento, assim como o consumo global da linha. A Figura 17 mostra o consumo de energia elétrica do sistema de manufatura de forma gráfica. Já a Figura 18 mostra a quantidade de unidades nos buffers em função do tempo.

Tabela 13 - Resultados de produtividade extraídos da simulação referente ao cenário A.

\begin{tabular}{|c|c|c|c|c|c|c|c|c|c|c|}
\hline Estação & Processo & $\begin{array}{l}\text { Quantidade } \\
\text { Produzida }\end{array}$ & & Buffers & & $\begin{array}{c}\text { Tempo em } \\
\text { processamento }\end{array}$ & $\begin{array}{c}\text { Tempo } \\
\text { aguardando }\end{array}$ & $\begin{array}{l}\text { Tempo em } \\
\text { bloqueio }\end{array}$ & $\begin{array}{l}\text { Tempo em } \\
\text { falha }\end{array}$ & $\begin{array}{c}\text { Tempo em } \\
\text { standby }\end{array}$ \\
\hline & & (un.) & $\begin{array}{c}\text { Capacidade } \\
\text { (un.) }\end{array}$ & $\begin{array}{l}\text { Quantidade } \\
\text { Inicial (un.) }\end{array}$ & $\begin{array}{c}\text { Ocupação } \\
\text { Máxima (un.) }\end{array}$ & (\%) & (\%) & $(\%)$ & (\%) & (\%) \\
\hline M1 & Estirar e cortar & 604.195 & & & & $100,00 \%$ & $0,00 \%$ & $0,00 \%$ & $0,00 \%$ & $0,00 \%$ \\
\hline M2 & Lavar e recozer & 604.194 & & & & $100,00 \%$ & $0,00 \%$ & $0,00 \%$ & $0,00 \%$ & $0,00 \%$ \\
\hline Buffer_1 & Buffer & & 60.000 & 0 & 1 & & & & & \\
\hline M3 & Conificar & 604.193 & & & & $97,20 \%$ & $2,80 \%$ & $0,00 \%$ & $0,00 \%$ & $0,00 \%$ \\
\hline M4 & Lavar & 604.192 & & & & $80,77 \%$ & $19,33 \%$ & $0,00 \%$ & $0,00 \%$ & $0,00 \%$ \\
\hline Buffer_2 & Buffer & & 60.000 & 0 & 1 & & & & & \\
\hline M5 & Tornear & 604.190 & & & & $100,00 \%$ & $0,00 \%$ & $0,00 \%$ & $0,00 \%$ & $0,00 \%$ \\
\hline M6 & Controlar & 604.189 & & & & $69,93 \%$ & $30,07 \%$ & $0,00 \%$ & $0,00 \%$ & $0,00 \%$ \\
\hline M7 & Recozer & 604.189 & & & & $80,42 \%$ & $19,58 \%$ & $0,00 \%$ & $0,00 \%$ & $0,00 \%$ \\
\hline Buffer_3 & Buffer & & 60.000 & 10.000 & 10.000 & & & & & \\
\hline M8 & Espoletar & 614.187 & & & & $100,00 \%$ & $0,00 \%$ & $0,00 \%$ & $0,00 \%$ & $0,00 \%$ \\
\hline Buffer_4 & Buffer & & 60.000 & 10.000 & 10.000 & & & & & \\
\hline M9 & Carregar & 624.185 & & & & $100,00 \%$ & $0,00 \%$ & $0,00 \%$ & $0,00 \%$ & $0,00 \%$ \\
\hline M10 & Impermeabilizar & 624.183 & & & & $100,00 \%$ & $0,00 \%$ & $0,00 \%$ & $0,00 \%$ & $0,00 \%$ \\
\hline M11 & Controlar & 624.182 & & & & $100,00 \%$ & $0,00 \%$ & $0,00 \%$ & $0,00 \%$ & $0,00 \%$ \\
\hline
\end{tabular}

Fonte: Autor (2018). 
Tabela 14 - Consumo de energia em estado de máquina referente à simulação do cenário A.

\begin{tabular}{|c|c|c|c|c|c|c|c|c|c|c|}
\hline \multirow[t]{2}{*}{ Estação } & \multirow[t]{2}{*}{ Processo } & \multirow{2}{*}{$\begin{array}{c}\text { Consumo Total } \\
\text { (kWh) }\end{array}$} & \multicolumn{2}{|c|}{$\begin{array}{l}\text { Consumo Estado } \\
\text { Processamento }\end{array}$} & \multicolumn{2}{|c|}{$\begin{array}{c}\text { Consumo Estado } \\
\text { Operacional }\end{array}$} & \multicolumn{2}{|c|}{$\begin{array}{l}\text { Consumo Estado } \\
\text { Manutenção }\end{array}$} & \multicolumn{2}{|c|}{$\begin{array}{c}\text { Consumo Estado } \\
\text { Standby }\end{array}$} \\
\hline & & & (\%) & $(\mathrm{kWh})$ & (\%) & $(\mathbf{k W h})$ & (\%) & $(\mathrm{kWh})$ & (\%) & (kWh) \\
\hline M1 & Estirar e cortar & $1.033,44$ & $100,00 \%$ & $1.033,44$ & & 0,00 & & 0,00 & & 0,00 \\
\hline M2 & Lavar e recozer & $2.235,36$ & $100,00 \%$ & $2.235,36$ & & 0,00 & & 0,00 & & 0,00 \\
\hline \multicolumn{11}{|c|}{ Buffer_1 Buffer } \\
\hline M3 & Conificar & 755,11 & $98,86 \%$ & 746,50 & $1,14 \%$ & 8,61 & & 0,00 & & 0,00 \\
\hline M4 & Lavar & 363,05 & $91,30 \%$ & 331,46 & $8,70 \%$ & 31,59 & & 0,00 & & 0,00 \\
\hline \multicolumn{11}{|c|}{ Buffer_2 Buffer } \\
\hline M5 & Tornear & 287,04 & $100,00 \%$ & 287,04 & & 0,00 & & 0,00 & & 0,00 \\
\hline M6 & Controlar & 130,97 & $85,34 \%$ & 111,77 & $14,66 \%$ & 19,20 & & 0,00 & & 0,00 \\
\hline M7 & Recozer & 771,44 & $91,12 \%$ & 702,94 & $8,88 \%$ & 68,50 & & 0,00 & & 0,00 \\
\hline \multicolumn{11}{|c|}{ Buffer_3 Buffer } \\
\hline M8 & Espoletar & 212,16 & $100,00 \%$ & 212,16 & & 0,00 & & 0,00 & & 0,00 \\
\hline \multicolumn{11}{|c|}{ Buffer_4 Buffer } \\
\hline M9 & Carregar & 179,04 & $100,00 \%$ & 179,04 & & 0,00 & & 0,00 & & 0,00 \\
\hline M10 & Impermeabilizar & 100,80 & $100,00 \%$ & 100,80 & & 0,00 & & 0,00 & & 0,00 \\
\hline M11 & Controlar & 87,84 & $100,00 \%$ & 87,84 & & 0,00 & & 0,00 & & 0,00 \\
\hline & & $6.156,25$ & $97,92 \%$ & $6.028,35$ & $2,08 \%$ & 127,90 & $0,00 \%$ & 0,00 & $0,00 \%$ & 0,00 \\
\hline
\end{tabular}

Fonte: Autor (2018).

Figura 17 - Gráfico de consumo de energia referente à simulação do cenário A.

\section{Consumo de Energia}

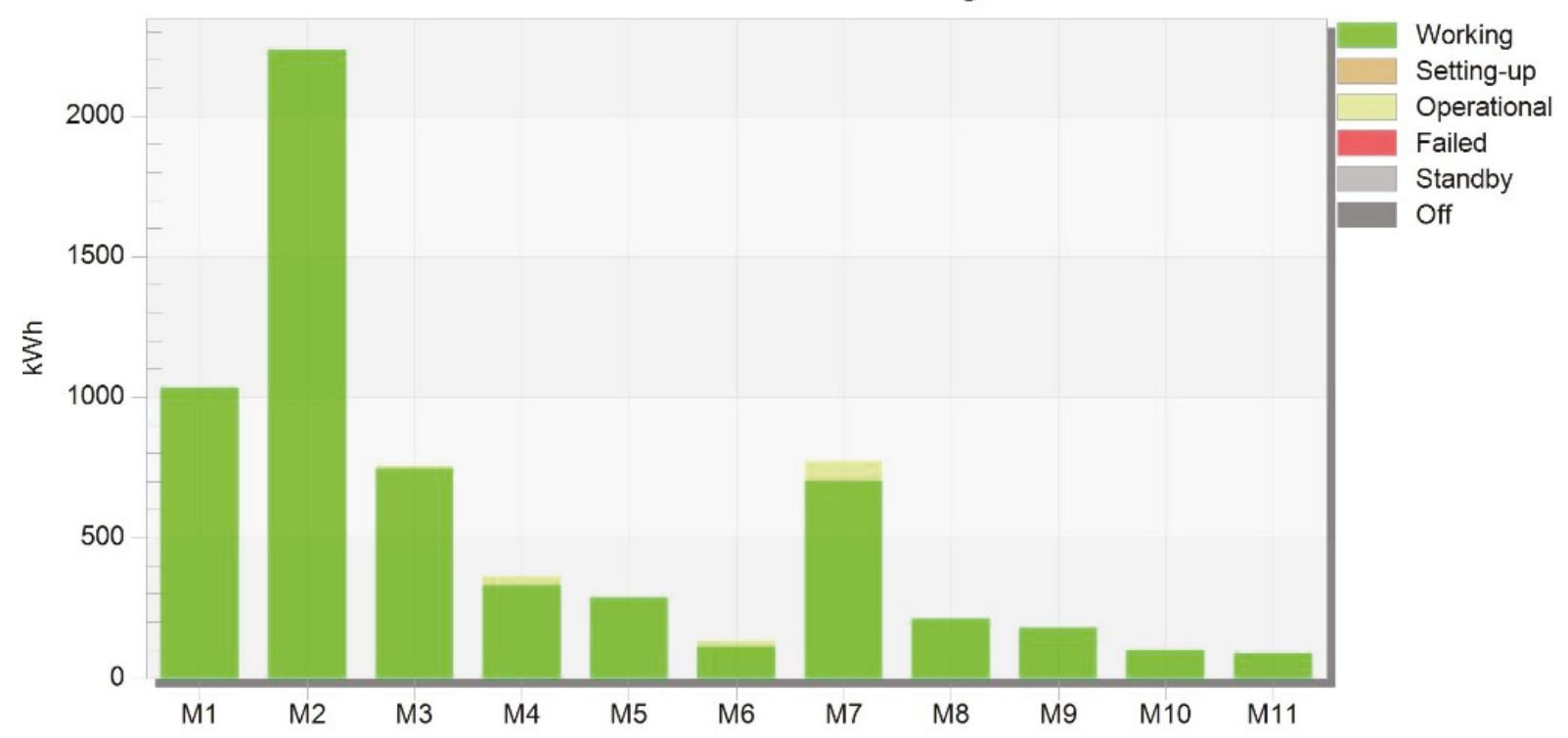

Fonte: Autor (2018). 
Figura 18 - Quantidade de unidades nos buffers durante a simulação do cenário A.

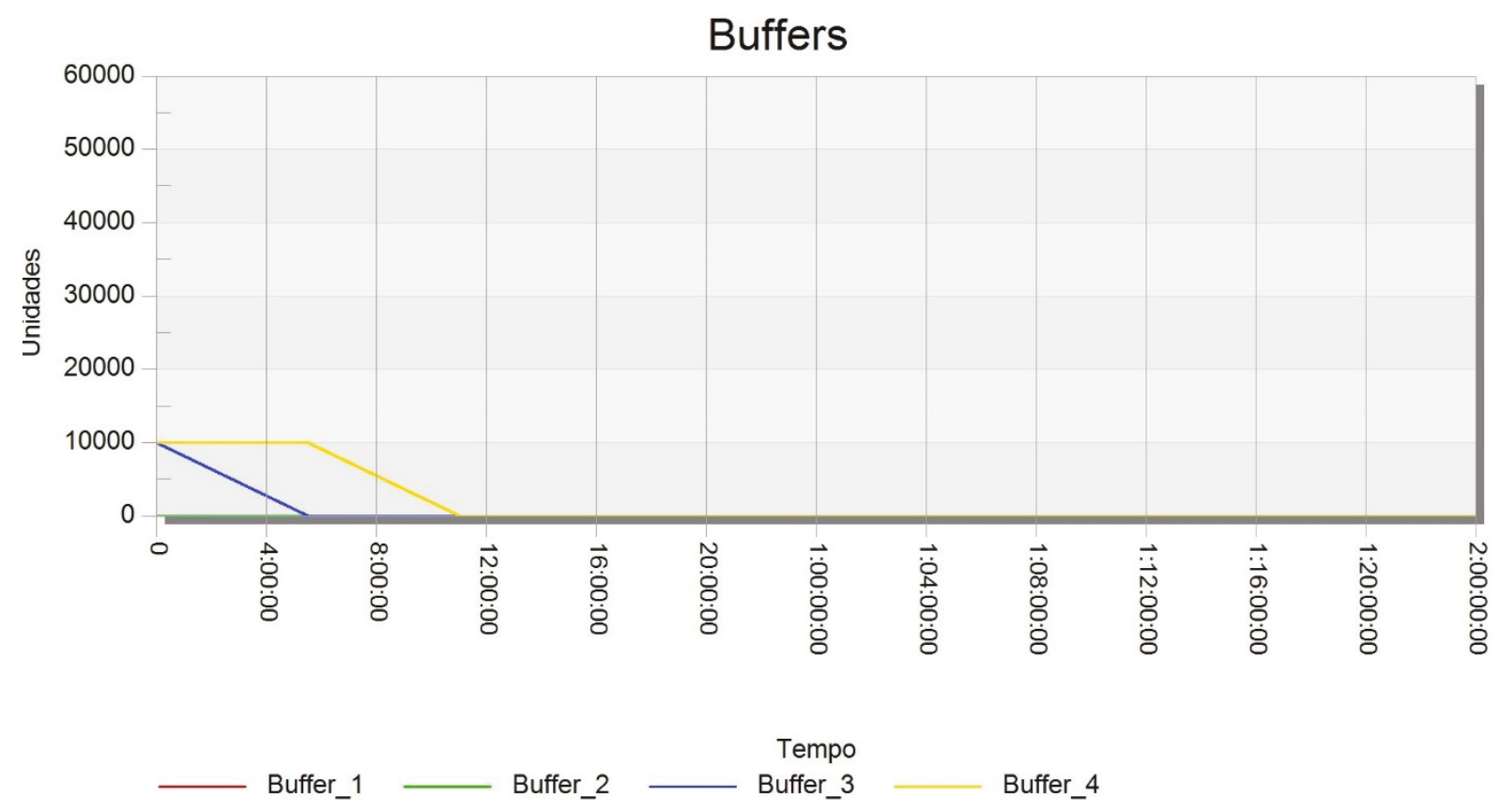

Fonte: Autor (2018).

\subsubsection{Cenário $B$}

O cenário avaliado representa a situação normal da linha de produção em estudo, uma vez que há ocorrências de paradas não-planejadas que impactam a produtividade do sistema de produção. O modelo abaixo representa a distribuição do sistema de manufatura e pode ser avaliado na Figura 19. Após as estações M2, M4, M7 e M8, o sistema utiliza buffers com capacidade máxima de 60.000 peças, sendo que o Buffer_3 e Buffer_4 devem iniciar a simulação com 10.000 unidades devido aos parâmetros de qualidade do produto. Desta forma, o cenário inicia com a quantidade de 10.000 unidades em cada um destes buffers, porém, como no cenário $\mathrm{A}$, não há controles de estados de máquinas a partir da quantidade de peças nos buffers. 
Figura 19 - Ilustração do modelo de simulação do cenário B.

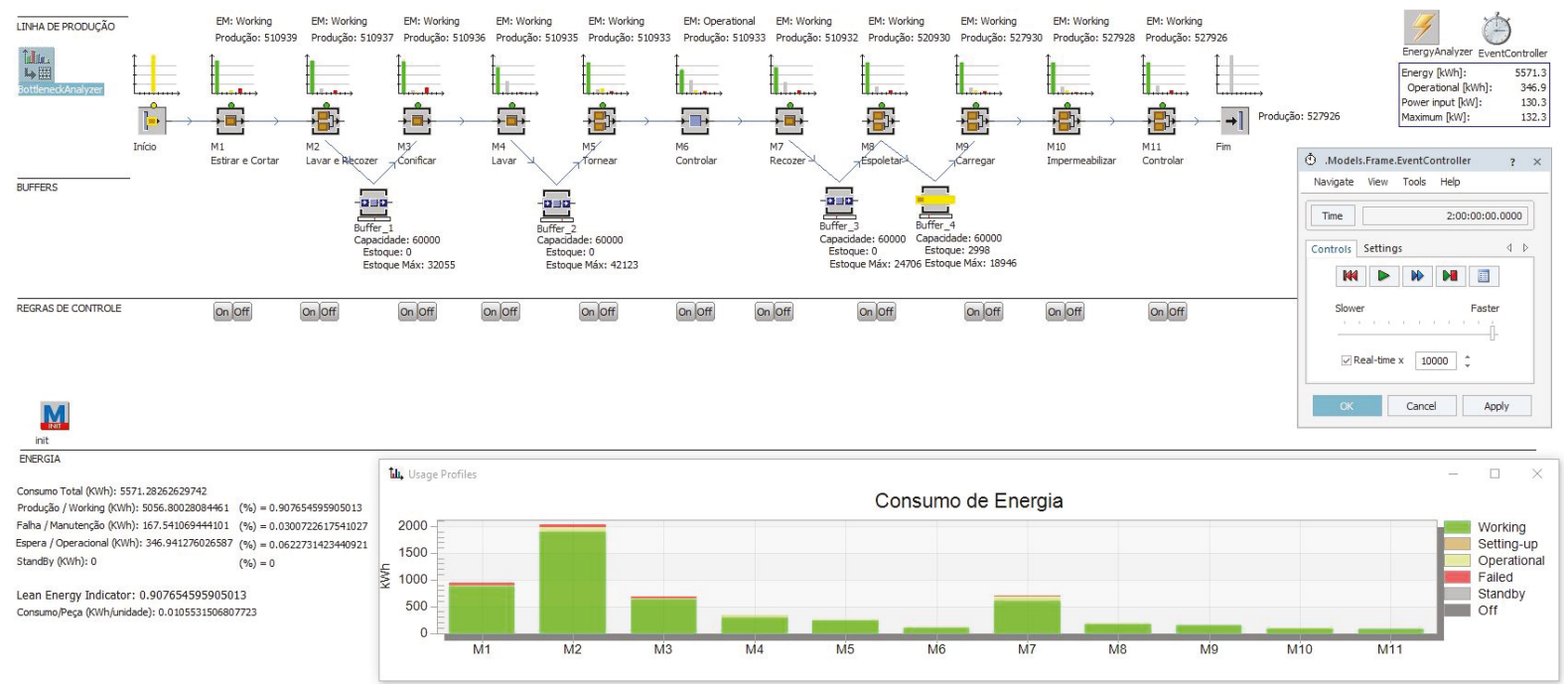

Fonte: Autor (2018).

Os dados de cada estação foram estratificados e apresentados em tópicos. A Tabela 15 apresenta os dados de produtividade. A Tabela 16 apresenta os valores absolutos de consumo individual de energia nos diferentes estados de máquina de cada equipamento, assim como o consumo global da linha. A Figura 20 mostra o consumo de energia elétrica do sistema de manufatura de forma gráfica. Já a Figura 21 mostra a quantidade de unidades nos buffers em função do tempo.

Tabela 15 - Resultados de produtividade extraídos da simulação referente ao cenário B.

\begin{tabular}{|c|c|c|c|c|c|c|c|c|c|c|}
\hline Estação & Processo & $\begin{array}{l}\text { Quantidade } \\
\text { Produzida }\end{array}$ & & Buffers & & $\begin{array}{c}\text { Tempo em } \\
\text { processamento }\end{array}$ & $\begin{array}{c}\text { Tempo } \\
\text { aguardando }\end{array}$ & $\begin{array}{l}\text { Tempo em } \\
\text { bloqueio }\end{array}$ & $\begin{array}{l}\text { Tempo em } \\
\text { falha }\end{array}$ & $\begin{array}{c}\text { Tempo em } \\
\text { standby }\end{array}$ \\
\hline & & (un.) & $\begin{array}{c}\text { Capacidade } \\
\text { (un.) }\end{array}$ & $\begin{array}{l}\text { Quantidade } \\
\text { Inicial (un.) }\end{array}$ & $\begin{array}{c}\text { Ocupação } \\
\text { Máxima (un.) }\end{array}$ & (\%) & (\%) & $(\%)$ & (\%) & (\%) \\
\hline M1 & Estirar e cortar & 510.939 & & & & $84,57 \%$ & $0,00 \%$ & $5,30 \%$ & $10,13 \%$ & $0,00 \%$ \\
\hline M2 & Lavar e recozer & 510.937 & & & & $84,57 \%$ & $9,69 \%$ & $0,00 \%$ & $5,74 \%$ & $0,00 \%$ \\
\hline Buffer_1 & Buffer & & 60.000 & 0 & 32.055 & & & & & \\
\hline M3 & Conificar & 513.936 & & & & $82,20 \%$ & $3,81 \%$ & $1,20 \%$ & $12,79 \%$ & $0,00 \%$ \\
\hline M4 & Lavar & 510.935 & & & & $68,30 \%$ & $30,50 \%$ & $0,00 \%$ & $1,20 \%$ & $0,00 \%$ \\
\hline Buffer_2 & Buffer & & 60.000 & 0 & 42.123 & & & & & \\
\hline M5 & Tornear & 510.933 & & & & $80,48 \%$ & $6,92 \%$ & $9,17 \%$ & $3,43 \%$ & $0,00 \%$ \\
\hline M6 & Controlar & 510.933 & & & & $59,14 \%$ & $31,37 \%$ & $5,99 \%$ & $3,50 \%$ & $0,00 \%$ \\
\hline M7 & Recozer & 510.932 & & & & $68,01 \%$ & $26,32 \%$ & $0,00 \%$ & $5,67 \%$ & $0,00 \%$ \\
\hline Buffer_3 & Buffer & & 60.000 & 10.000 & 24.706 & & & & & \\
\hline M8 & Espoletar & 520.930 & & & & $80,41 \%$ & $14,19 \%$ & $0,00 \%$ & $5,40 \%$ & $0,00 \%$ \\
\hline Buffer_4 & Buffer & & 60.000 & 10.000 & 18.946 & & & & & \\
\hline M9 & Carregar & 527.930 & & & & $78,97 \%$ & $12,39 \%$ & $4,90 \%$ & $3,74 \%$ & $0,00 \%$ \\
\hline M10 & Impermeabilizar & 527.928 & & & & $78,97 \%$ & $16,13 \%$ & $3,80 \%$ & $1,10 \%$ & $0,00 \%$ \\
\hline M11 & Controlar & 527.926 & & & & $78,97 \%$ & $17,23 \%$ & $0,00 \%$ & $3,80 \%$ & $0,00 \%$ \\
\hline
\end{tabular}

Fonte: Autor (2018). 
Tabela 16 - Consumo de energia em estado de máquina referente à simulação do cenário B.

\begin{tabular}{|c|c|c|c|c|c|c|c|c|c|c|}
\hline \multirow[t]{2}{*}{ Estação } & \multirow[t]{2}{*}{ Processo } & \multirow{2}{*}{$\begin{array}{c}\text { Consumo Total } \\
\text { (kWh) }\end{array}$} & \multicolumn{2}{|c|}{$\begin{array}{l}\text { Consumo Estado } \\
\text { Processamento }\end{array}$} & \multicolumn{2}{|c|}{$\begin{array}{c}\text { Consumo Estado } \\
\text { Operacional }\end{array}$} & \multicolumn{2}{|c|}{$\begin{array}{l}\text { Consumo Estado } \\
\text { Manutenção }\end{array}$} & \multicolumn{2}{|c|}{$\begin{array}{c}\text { Consumo Estado } \\
\text { Standby }\end{array}$} \\
\hline & & & (\%) & $(\mathrm{kWh})$ & (\%) & $(\mathrm{kWh})$ & (\%) & $(\mathrm{kWh})$ & $(\%)$ & (kWh) \\
\hline M1 & Estirar e cortar & 937,72 & $93,20 \%$ & 873,96 & $2,34 \%$ & 21,94 & $4,47 \%$ & 41,92 & & 0,00 \\
\hline M2 & Lavar e recozer & $2.028,37$ & $93,20 \%$ & $1.890,44$ & $4,27 \%$ & 86,61 & $2,53 \%$ & 51,32 & & 0,00 \\
\hline \multicolumn{11}{|c|}{ Buffer_1 Buffer } \\
\hline M3 & Conificar & 685,97 & $92,03 \%$ & 631,30 & $2,24 \%$ & 15,37 & $5,73 \%$ & 39,31 & & 0,00 \\
\hline M4 & Lavar & 332,35 & $84,34 \%$ & 280,30 & $15,06 \%$ & 50,05 & $0,59 \%$ & 1,96 & & 0,00 \\
\hline \multicolumn{11}{|c|}{ Buffer_2 Buffer } \\
\hline M5 & Tornear & 253,41 & $91,16 \%$ & 231,01 & $7,28 \%$ & 18,45 & $1,55 \%$ & 3,93 & & 0,00 \\
\hline M6 & Controlar & 120,61 & $78,37 \%$ & 94,52 & $19,78 \%$ & 23,86 & $1,85 \%$ & 2,23 & & 0,00 \\
\hline M7 & Recozer & 706,38 & $84,15 \%$ & 594,42 & $13,04 \%$ & 92,11 & $2,81 \%$ & 19,85 & & 0,00 \\
\hline Buffer_3 & Buffer & & & & & & & 0,00 & & 0,00 \\
\hline M8 & Espoletar & 187,24 & $91,11 \%$ & 170,59 & $6,44 \%$ & 12,06 & $2,45 \%$ & 4,59 & & 0,00 \\
\hline \multicolumn{11}{|c|}{ Buffer_4 Buffer } \\
\hline M9 & Carregar & 154,42 & $91,56 \%$ & 141,39 & $8,01 \%$ & 12,37 & $0,43 \%$ & 0,66 & & 0,00 \\
\hline M10 I & Impermeabilizar & 88,08 & $90,37 \%$ & 79,60 & $9,12 \%$ & 8,03 & $0,51 \%$ & 0,45 & & 0,00 \\
\hline M11 & Controlar & 76,74 & $90,40 \%$ & 69,37 & $7,87 \%$ & 6,04 & $1,73 \%$ & 1,33 & & 0,00 \\
\hline & & $5.571,29$ & $90,77 \%$ & $5.056,90$ & $6,23 \%$ & 346,89 & $3,01 \%$ & 167,54 & $0,00 \%$ & 0,00 \\
\hline
\end{tabular}

Fonte: Autor (2018).

Figura 20 - Gráfico de consumo de energia referente à simulação do cenário B.

\section{Consumo de Energia}

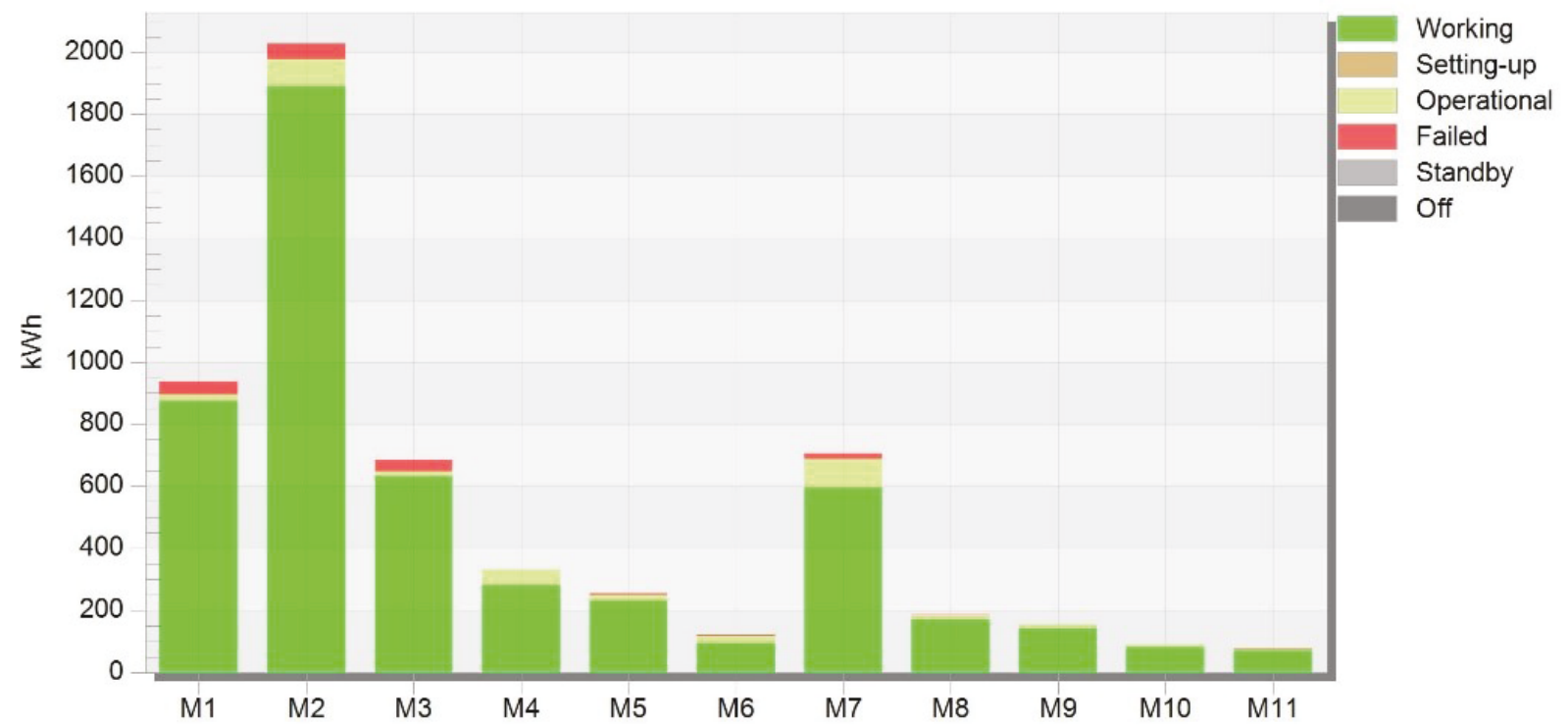

Fonte: Autor (2018). 
Figura 21 - Quantidade de unidades nos buffers em função do tempo do cenário B.

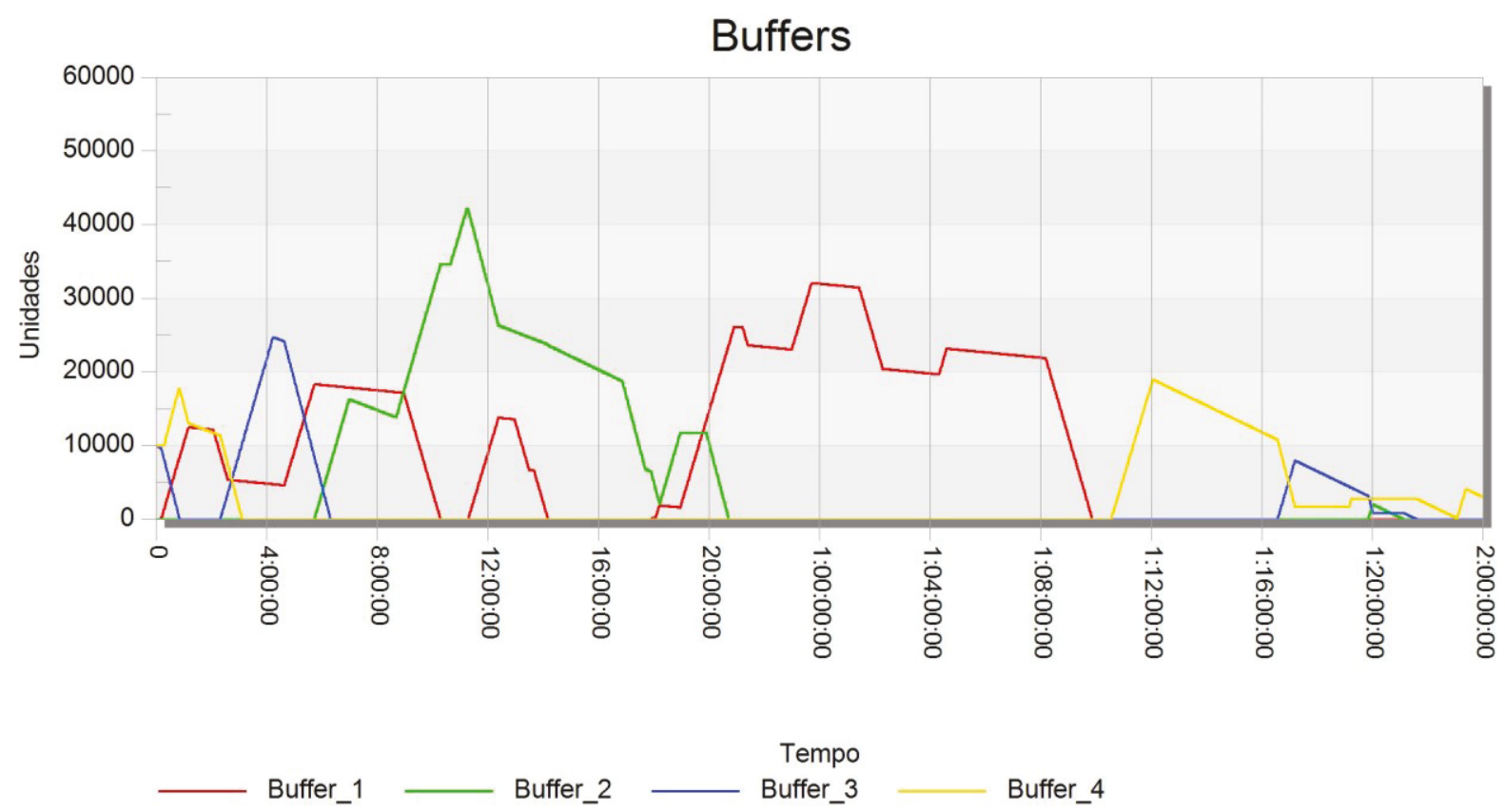

Fonte: Autor (2018).

\subsubsection{Cenário $\mathrm{C}$}

O cenário avaliado utiliza como base os parâmetros do cenário $\mathrm{B}$, entretanto, neste cenário há o gerenciamento de estados de máquina através da aplicação de regras de programação, que visam controlar a quantidade de peças presentes nos buffers e alterar os estados de máquinas em função deste parâmetro. Estas regras basicamente foram conectadas aos buffers existentes no sistema de manufatura, após as estações M2, M4, M7 e M8, com capacidade máxima de 60.000 peças, sendo que o Buffer_3 e Buffer_4 devem iniciar a simulação com 10.000 unidades devido aos parâmetros de qualidade do produto, e nos sistemas de alimentação de cada estação de trabalho, que, caso necessário, pode ser alterado pela empresa para o tipo de alimentação direta para buffer, operando com até 10.000 unidades no sistema e mínimo de 1.000 unidades para que o sensor possa identificar a falta de material. Desta forma, seguem abaixo as regras que foram utilizadas neste cenário:

a) Regra 1: quando a quantidade de peças do Buffer_1 for igual a zero, a estação M3 deve entrar em modo Standby;

b) Regra 2: quando a quantidade de peças do Buffer_2 for igual a zero, a estação M5 deve entrar em modo Standby;

c) Regra 3: quando a quantidade de peças do Buffer_3 for menor que dez mil unidades, a estação M8 deve entrar em modo Standby; 
d) Regra 4: quando a quantidade de peças do Buffer_4 for menor que dez mil unidades, a estação M9 deve entrar em modo Standby;

e) Regra 5: quando a quantidade de peças no sistema de alimentação de M2 for menor que 1.000 unidades, a estação M2 deve entrar em modo Standby ou quando a quantidade de peças no sistema de alimentação de M2 for igual a 10.000 unidades, a estação M1 deve entrar em modo Standby;

f) Regra 6: quando a quantidade de peças no sistema de alimentação de M4 for menor que 1.000 unidades, a estação M4 deve entrar em modo Standby ou quando a quantidade de peças no sistema de alimentação de M4 for igual a 10.000 unidades, a estação M3 deve entrar em modo Standby;

g) Regra 7: quando a quantidade de peças no sistema de alimentação de M6 for menor que 1.000 unidades, a estação M6 deve entrar em modo Standby ou quando a quantidade de peças no sistema de alimentação de M6 for igual a 10.000 unidades, a estação M5 deve entrar em modo Standby;

h) Regra 8: quando a quantidade de peças no sistema de alimentação de M7 for menor que 1.000 unidades, a estação M7 deve entrar em modo Standby ou quando a quantidade de peças no sistema de alimentação de M7 for igual a 10.000 unidades, a estação M6 deve entrar em modo Standby;

i) Regra 9: quando a quantidade de peças no sistema de alimentação de M10 for menor que 1.000 unidades, a estação M10 deve entrar em modo Standby ou quando a quantidade de peças no sistema de alimentação de M10 for igual a 10.000 unidades, a estação M9 deve entrar em modo Standby;

j) Regra 10: quando a quantidade de peças no sistema de alimentação de M11 for menor que 1.000 unidades, a estação M11 deve entrar em modo Standby ou quando a quantidade de peças no sistema de alimentação de M11 for igual a 10.000 unidades, a estação M10 deve entrar em modo Standby;

O modelo abaixo representa a distribuição do sistema de manufatura, bem como a presença dos sistemas de alimentação trabalhando em modo buffer e seguindo regras de programação representadas pelo ícone com letra M (Métodos), o que pode ser avaliado na Figura 22. 
Figura 22 - Ilustração do modelo de simulação do cenário C.

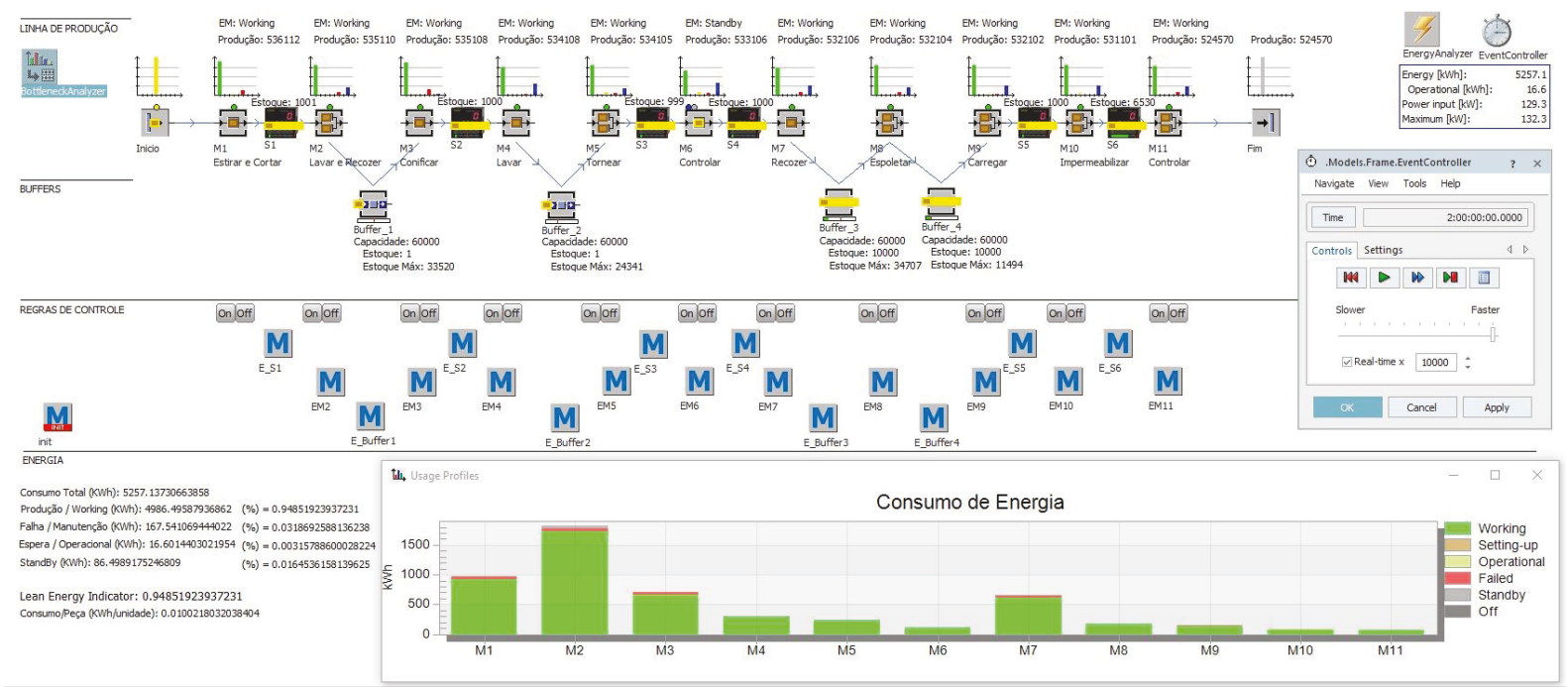

Fonte: Autor (2018).

Os dados de cada estação foram estratificados e apresentados em tópicos. A Tabela 17 apresenta os dados de produtividade. A Tabela 18 apresenta os valores absolutos de consumo individual de energia nos diferentes estados de máquina de cada equipamento, assim como o consumo global da linha. A Figura 23 mostra o consumo de energia elétrica do sistema de manufatura de forma gráfica. Já as Figura 24 e Figura 25 mostram a quantidade de unidades nos buffers e dos sistemas de alimentação em função do tempo em função do tempo.

Tabela 17 - Resultados de produtividade extraídos da simulação referente ao cenário C.

\begin{tabular}{|c|c|c|c|c|c|c|c|c|c|c|}
\hline \multirow[t]{2}{*}{ Estação } & \multirow[t]{2}{*}{ Processo } & \multirow{2}{*}{$\begin{array}{c}\text { Quantidade } \\
\text { Produrida } \\
\text { (un.) }\end{array}$} & \multicolumn{3}{|c|}{ Buffers } & \multirow{2}{*}{$\begin{array}{c}\text { Tempo em } \\
\text { processamento } \\
(\%)\end{array}$} & \multirow{2}{*}{\begin{tabular}{|c|} 
Tempo \\
aguardando
\end{tabular}} & \multirow{2}{*}{$\begin{array}{c}\text { Tempo em } \\
\text { bloqueio } \\
(\%)\end{array}$} & \multirow{2}{*}{$\begin{array}{c}\text { Tempo em } \\
\text { falha } \\
\%)\end{array}$} & \multirow{2}{*}{$\begin{array}{c}\text { Tempo em } \\
\text { standby } \\
\%)\end{array}$} \\
\hline & & & $\begin{array}{l}\text { Capacidade } \\
\text { (un.) }\end{array}$ & $\begin{array}{l}\text { Quantidade } \\
\text { Inicial (un.) }\end{array}$ & $\begin{array}{c}\text { Ocupação } \\
\text { Máxima (un.) }\end{array}$ & & & & & \\
\hline M1 & Estirar e cortar & 536.112 & & & & $88,73 \%$ & $0,00 \%$ & $1,14 \%$ & $10,13 \%$ & $0,00 \%$ \\
\hline S1 & Alimentação 1 & & 10.000 & 0 & 10.000 & & & & & \\
\hline M2 & Lavar e recozer & 535.110 & & & & $77,42 \%$ & $0,00 \%$ & $0,00 \%$ & $5,52 \%$ & $17,06 \%$ \\
\hline Buffer_1 & Buffer & & 60.000 & 0 & 33.520 & & & & & \\
\hline M3 & Conificar & 535.108 & & & & $86,09 \%$ & $0,17 \%$ & $0,00 \%$ & $12,79 \%$ & $0,96 \%$ \\
\hline S2 & Alimentação 2 & & 10.000 & 0 & 4.872 & & & & & \\
\hline M4 & Lavar & 534.108 & & & & $71,40 \%$ & $0,00 \%$ & $0,00 \%$ & $1,20 \%$ & $27,40 \%$ \\
\hline Buffer_2 & Buffer & & 60.000 & 0 & 24.341 & & & & & \\
\hline M5 & Tornear & 534.105 & & & & $77,27 \%$ & $0,17 \%$ & $4,94 \%$ & $2,62 \%$ & $15,01 \%$ \\
\hline S3 & Alimentação 3 & & 10.000 & 0 & 10.000 & & & & & \\
\hline M6 & Controlar & 533.106 & & & & $61,70 \%$ & $0,00 \%$ & $5,87 \%$ & $3,50 \%$ & $28,92 \%$ \\
\hline S4 & Alimentação 4 & & 10.000 & 0 & 10.000 & & & & & \\
\hline M7 & Recozer & 532.106 & & & & $70,82 \%$ & $0,00 \%$ & $0,00 \%$ & $5,67 \%$ & $23,50 \%$ \\
\hline Buffer_3 & Buffer & & 60.000 & 10.000 & 34.707 & & & & & \\
\hline M8 & Espoletar & 532.104 & & & & $76,98 \%$ & $0,00 \%$ & $0,00 \%$ & $5,40 \%$ & $17,62 \%$ \\
\hline Buffer_4 & Buffer & & 60.000 & 10.000 & 11.494 & & & & & \\
\hline M9 & Carregar & 532.102 & & & & $76,98 \%$ & $0,00 \%$ & $0,24 \%$ & $0,16 \%$ & $22,62 \%$ \\
\hline S5 & Alimentação 5 & & 10.000 & 0 & 10.000 & & & & & \\
\hline M10 & Impermeabilizar & 531.101 & & & & $76,84 \%$ & $0,00 \%$ & $1,69 \%$ & $0,00 \%$ & $21,47 \%$ \\
\hline S6 & Alimentação 6 & & 10.000 & 0 & 10.000 & & & & & \\
\hline M11 & Controlar & 524.570 & & & & $75,89 \%$ & $0,00 \%$ & $0,00 \%$ & $3,80 \%$ & $20,31 \%$ \\
\hline
\end{tabular}

Fonte: Autor (2018). 
Tabela 18 - Consumo de energia em estado de máquina referente a simulação do cenário C.

\begin{tabular}{|c|c|c|c|c|c|c|c|c|c|c|}
\hline \multirow[t]{2}{*}{ Estação } & \multirow[t]{2}{*}{ Processo } & \multirow{2}{*}{$\begin{array}{c}\text { Consumo Total } \\
\text { (kWh) }\end{array}$} & \multicolumn{2}{|c|}{$\begin{array}{l}\text { Consumo Estado } \\
\text { Processamento }\end{array}$} & \multicolumn{2}{|c|}{$\begin{array}{c}\text { Consumo Estado } \\
\text { Operacional }\end{array}$} & \multicolumn{2}{|c|}{$\begin{array}{l}\text { Consumo Estado } \\
\text { Manutenção }\end{array}$} & \multicolumn{2}{|c|}{$\begin{array}{c}\text { Consumo Estado } \\
\text { Standby }\end{array}$} \\
\hline & & & (\%) & $(\mathrm{kWh})$ & (\%) & (kWh) & (\%) & $(\mathrm{kWh})$ & (\%) & $(\mathrm{kWh})$ \\
\hline M1 & Estirar e cortar & 963,56 & $95,17 \%$ & 917,02 & $0,49 \%$ & 4,72 & $4,35 \%$ & 41,91 & $0,00 \%$ & 0,00 \\
\hline $\mathrm{S} 1$ & Alimentação 1 & & & & & & & & & \\
\hline M2 & Lavar e recozer & $1.819,59$ & $95,11 \%$ & $1.730,61$ & $0,00 \%$ & 0,00 & $2,82 \%$ & 51,31 & $2,07 \%$ & 37,67 \\
\hline \multicolumn{11}{|c|}{ Buffer_1 Buffer } \\
\hline M3 & Conificar & 701,31 & $94,27 \%$ & 661,12 & $0,00 \%$ & 0,00 & $5,60 \%$ & 39,27 & $0,12 \%$ & 0,84 \\
\hline $\mathrm{S} 2$ & Alimentação 2 & & & & & & & & & \\
\hline M4 & Lavar & 306,31 & $95,66 \%$ & 293,02 & $0,00 \%$ & 0,00 & $0,64 \%$ & 1,96 & $3,69 \%$ & 11,30 \\
\hline \multicolumn{11}{|c|}{ Buffer_2 Buffer } \\
\hline M5 & Tornear & 235,54 & $94,17 \%$ & 221,81 & $2,40 \%$ & 5,65 & $1,67 \%$ & 3,93 & $1,76 \%$ & 4,15 \\
\hline S3 & Alimentação 3 & & & & & & & & & \\
\hline M6 & Controlar & 109,19 & $90,32 \%$ & 98,62 & $3,43 \%$ & 3,75 & $2,05 \%$ & 2,24 & $4,20 \%$ & 4,59 \\
\hline $\mathrm{S} 4$ & Alimentação 4 & & & & & & & & & \\
\hline M7 & Recozer & 659,44 & $93,88 \%$ & 619,08 & $0,00 \%$ & 0,00 & $3,01 \%$ & 19,85 & $3,11 \%$ & 20,51 \\
\hline Buffer_3 & Buffer & & & & & & & & & 0,00 \\
\hline M8 & Espoletar & 171,64 & $95,16 \%$ & 163,33 & $0,00 \%$ & 0,00 & $2,67 \%$ & 4,58 & $2,17 \%$ & 3,72 \\
\hline \multicolumn{11}{|c|}{ Buffer 4 Buffer } \\
\hline M9 & Carregar & 139,84 & $98,57 \%$ & 137,84 & $0,96 \%$ & 1,34 & $0,47 \%$ & 0,66 & $0,00 \%$ & 0,00 \\
\hline S5 & Alimentação 5 & & & & & & & & & \\
\hline M10 & Impermeabilizar & 80,98 & $95,64 \%$ & 77,45 & $1,42 \%$ & 1,15 & $0,55 \%$ & 0,45 & $2,39 \%$ & 1,94 \\
\hline S6 & Alimentação 6 & & & & & & & & & \\
\hline M11 & Controlar & 69,75 & $95,58 \%$ & 66,67 & $0,00 \%$ & 0,00 & $1,91 \%$ & 1,33 & $2,52 \%$ & 1,76 \\
\hline & & $5.257,15$ & $94,85 \%$ & $4.986,57$ & $0,32 \%$ & 16,61 & $3,19 \%$ & 167,50 & $1,64 \%$ & 86,47 \\
\hline
\end{tabular}

Fonte: Autor (2018).

Figura 23 - Gráfico de consumo de energia referente à simulação do cenário C.

\section{Consumo de Energia}

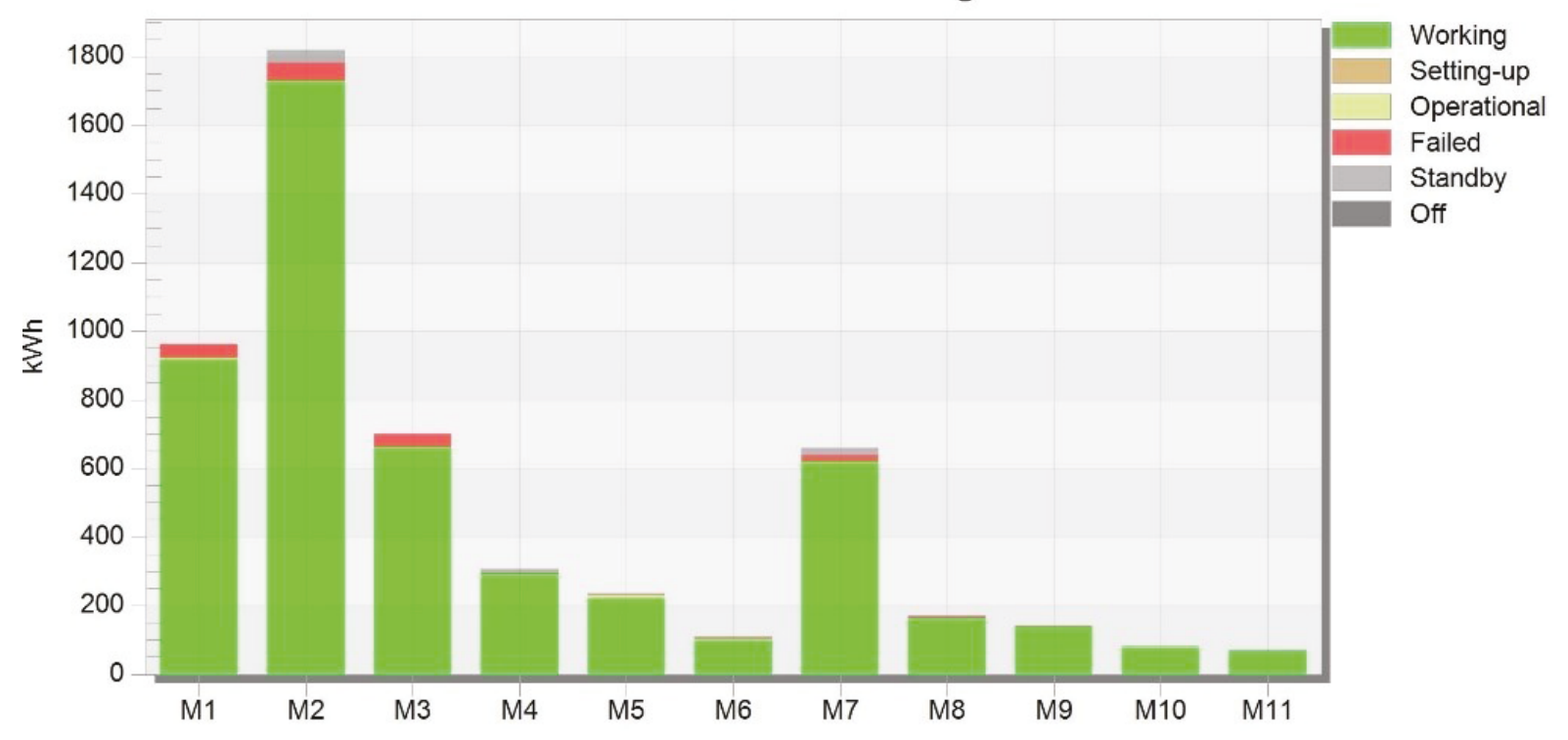

Fonte: Autor (2018). 
Figura 24 - Quantidade de unidades nos buffers durante a simulação do cenário C.

\section{Buffers}

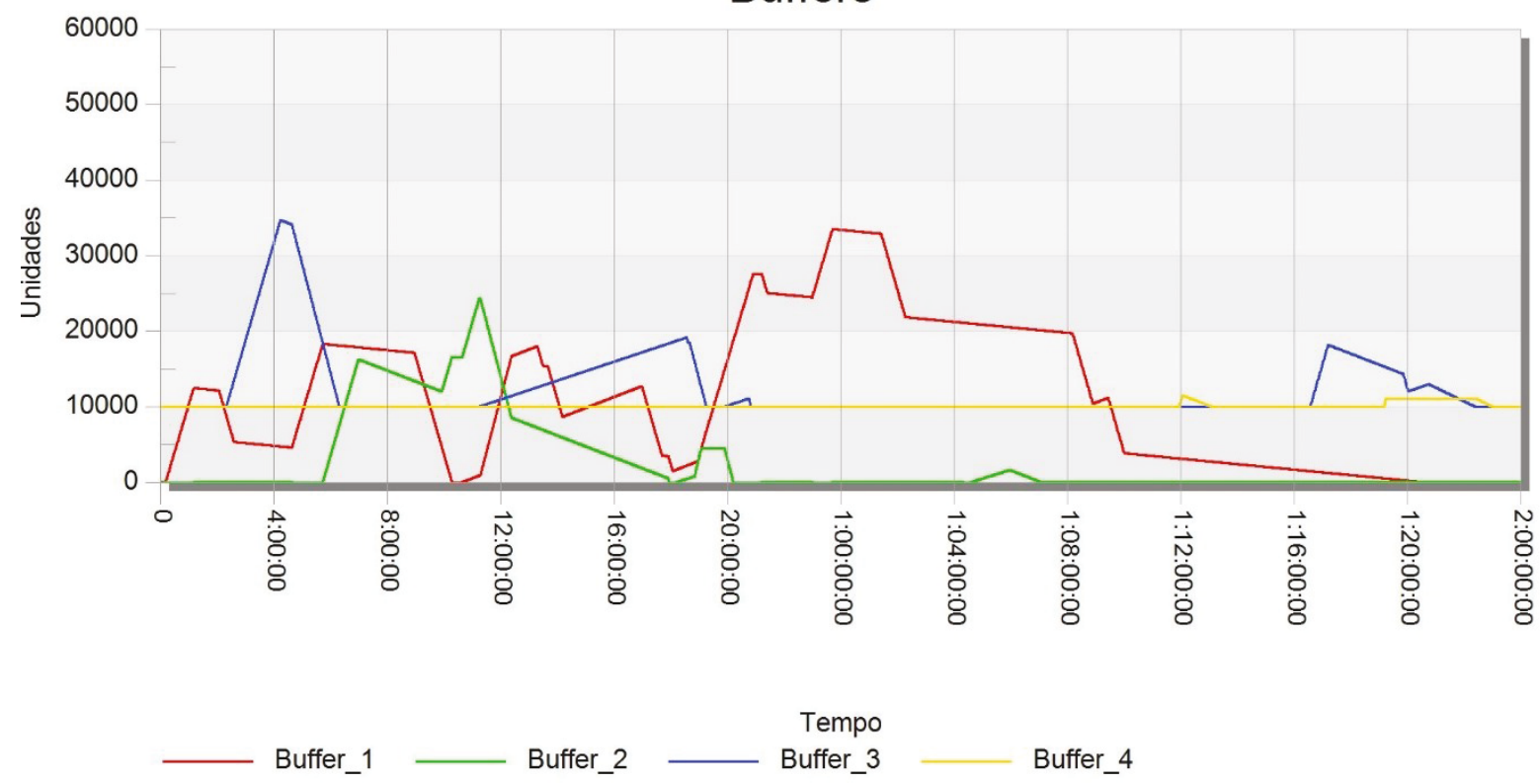

Fonte: Autor (2018).

Figura 25 - Quantidade de unidades nos sistemas de alimentação durante a simulação do cenário $\mathrm{C}$.

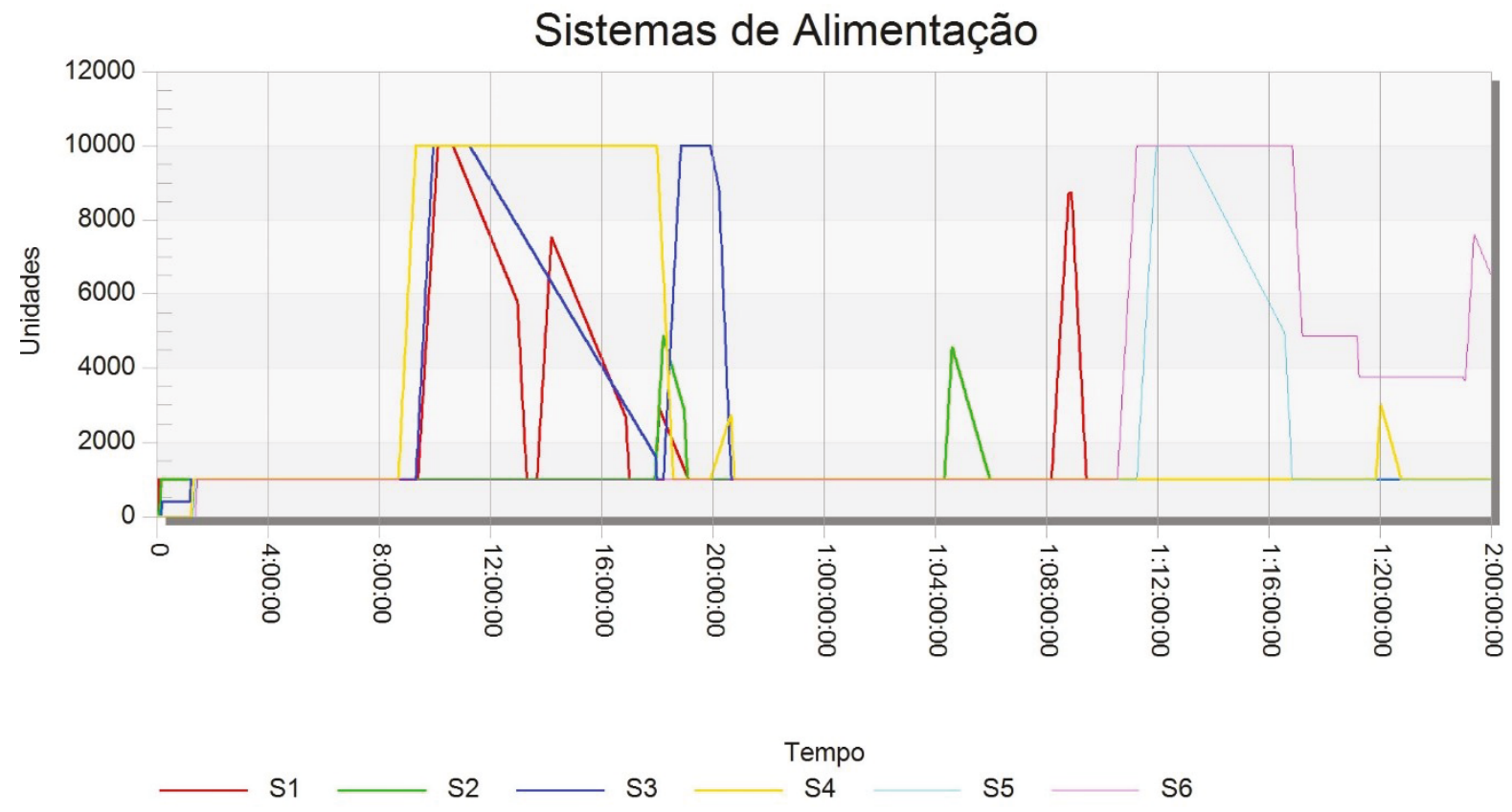

Fonte: Autor (2018). 


\subsubsection{Cenário D}

O cenário avaliado representa a situação planejada da linha de produção em estudo, uma vez que as ocorrências de paradas não-planejadas foram substituídas por paradas planejadas diárias de 1 horas para realizar as manutenções e ajustes necessários em cada equipamento do processo. Além disso, as regras de programação aplicadas ao cenário C estão presentes também neste cenário. Utilizou-se este planejamento de paradas de manutenção com o objetivo de avaliar se este tipo de regra de programação pode auxiliar na obtenção de melhores resultados para sistemas de manufatura de ciclos curtos, uma vez que as paradas aleatórias podem representar perdas de produtividade significativas, bem como se haverá impacto no consumo energético.

As paradas planejadas são realizadas de acordo com a sequência apresentada na Tabela 19, uma vez que, conforme informações da empresa, a equipe de manutenção não consegue atuar em todos os equipamentos de uma única vez.

Tabela 19 - Parâmetros de paradas planejadas.

\begin{tabular}{|c|c|c|c|c|}
\hline \multirow{2}{*}{ Estação } & \multirow{2}{*}{ Processo } & \multicolumn{3}{|c|}{ Paradas Planejadas de Manutenção e Ajustes } \\
\hline & & $\begin{array}{c}\text { Início } \\
\text { (hh:mm:ss) }\end{array}$ & Duração (min) & $\begin{array}{c}\text { Intervalo } \\
\text { (hh:mm:ss) }\end{array}$ \\
\hline M1 & Estirar e cortar & 20:00:00 & \multirow{11}{*}{60} & \multirow{11}{*}{ 23:00:00 } \\
\hline M2 & Lavar e recozer & 20:00:00 & & \\
\hline M3 & Conificar & 19:00:00 & & \\
\hline M4 & Lavar & 19:00:00 & & \\
\hline M5 & Tornear & 18:00:00 & & \\
\hline M6 & Controlar & 18:00:00 & & \\
\hline M7 & Recozer & 18:00:00 & & \\
\hline M8 & Espoletar & 17:00:00 & & \\
\hline M9 & Carregar & 16:00:00 & & \\
\hline M10 & Impermeabilizar & $16: 00: 00$ & & \\
\hline M11 & Controlar & $16: 00: 00$ & & \\
\hline
\end{tabular}

Fonte: Autor (2018).

O modelo abaixo representa a distribuição do sistema de manufatura, bem como a presença dos sistemas de alimentação e das regras de programação representadas pelo ícone com letra M (Métodos), conforme apresentado no cenário D (Figura 26). 
Figura 26 - Ilustração do modelo de simulação do cenário D.

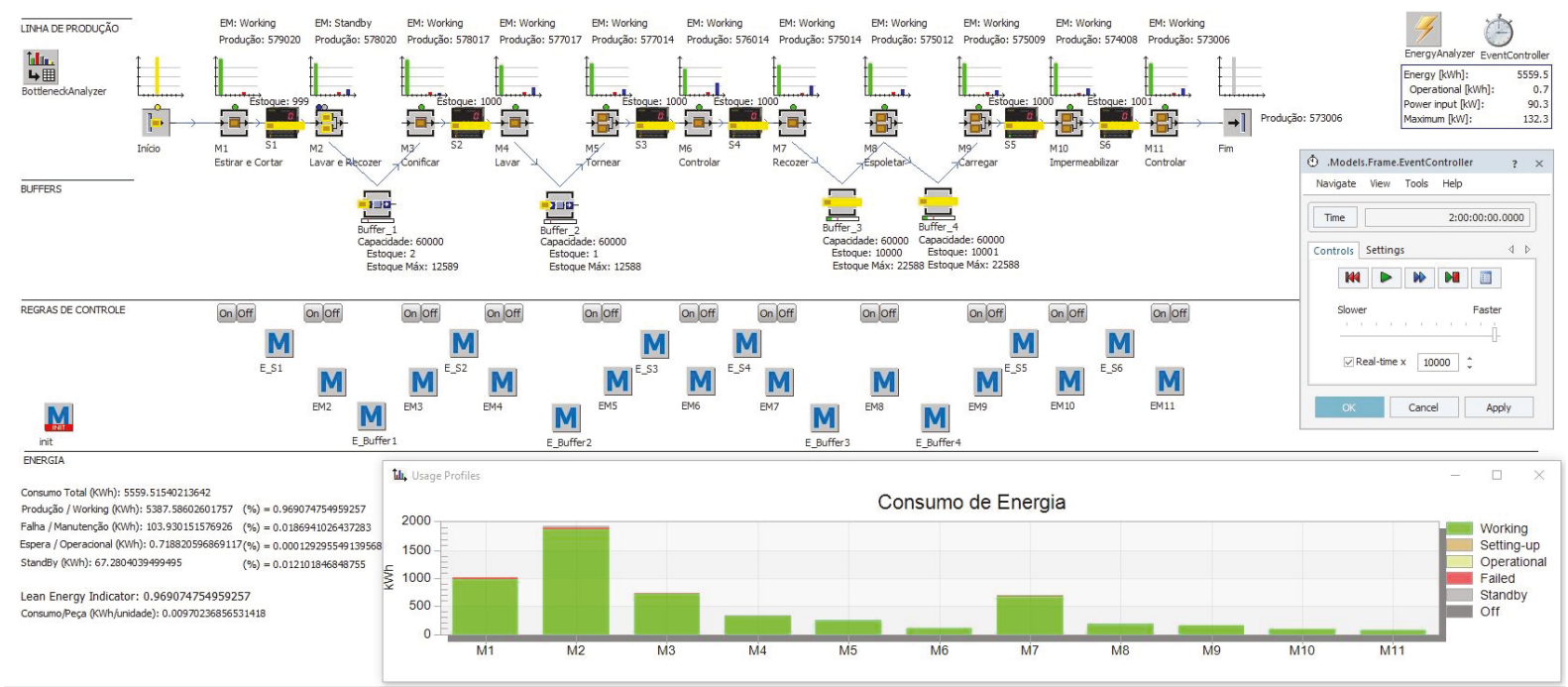

Fonte: Autor (2018).

Os dados de cada estação foram estratificados e apresentados em tópicos. A Tabela 20 apresenta os dados de produtividade. A Tabela 21 apresenta os valores absolutos de consumo individual de energia nos diferentes estados de máquina de cada equipamento, assim como o consumo global da linha. A Figura 27 mostra o consumo de energia elétrica do sistema de manufatura de forma gráfica. Já as Figura 28 e Figura 29 mostram a quantidade de unidades nos buffers e dos sistemas de alimentação em função do tempo em função do tempo.

Tabela 20 - Resultados de produtividade extraídos da simulação referente ao cenário D.

\begin{tabular}{|c|c|c|c|c|c|c|c|c|c|c|}
\hline \multirow{2}{*}{ Estação } & \multirow{2}{*}{ Processo } & \multirow{2}{*}{$\begin{array}{c}\text { Quantidade } \\
\text { Produzida } \\
\text { (un.) }\end{array}$} & \multicolumn{3}{|c|}{ Buffers } & \multirow{2}{*}{$\begin{array}{c}\text { Tempo em } \\
\text { processamento } \\
\text { (\%) }\end{array}$} & \multirow{2}{*}{$\begin{array}{c}\text { Tempo } \\
\text { aguardando } \\
\%)\end{array}$} & \multirow{2}{*}{$\begin{array}{c}\text { Tempo em } \\
\text { bloqueio } \\
\text { (\%) }\end{array}$} & \multirow{2}{*}{$\begin{array}{c}\text { Tempo em } \\
\text { falha } \\
\%\end{array}$} & \multirow{2}{*}{$\begin{array}{c}\text { Tempo em } \\
\text { standby } \\
(\%)\end{array}$} \\
\hline & & & $\begin{array}{c}\text { Capacidade } \\
\text { (un.) }\end{array}$ & $\begin{array}{l}\text { Quantidade } \\
\text { Inicial (un.) }\end{array}$ & $\begin{array}{c}\text { Ocupação } \\
\text { Máxima (un.) }\end{array}$ & & & & & \\
\hline M1 & Estirar e cortar & 579.020 & & & & $95,83 \%$ & $0,00 \%$ & $0,00 \%$ & $4,17 \%$ & $0,00 \%$ \\
\hline S1 & Alimentação 1 & & 10.000 & 0 & 1.001 & & & & & \\
\hline M2 & Lavar e recozer & 578.020 & & & & $83,63 \%$ & $0,00 \%$ & $0,00 \%$ & $4,16 \%$ & $12,21 \%$ \\
\hline Buffer_1 & Buffer & & 60.000 & 0 & 12.589 & & & & & \\
\hline $\mathrm{M} 3$ & Conificar & 578.017 & & & & $92,99 \%$ & $0,17 \%$ & $0,00 \%$ & $4,16 \%$ & $2,68 \%$ \\
\hline S2 & Alimentação 2 & & 10.000 & 0 & 1.001 & & & & & \\
\hline M4 & Lavar & 577.017 & & & & $77,14 \%$ & $0,00 \%$ & $0,00 \%$ & $4,16 \%$ & $18,70 \%$ \\
\hline Buffer_2 & Buffer & & 60.000 & 0 & 12.588 & & & & & \\
\hline M5 & Tornear & 577.014 & & & & $83,48 \%$ & $0,17 \%$ & $0,00 \%$ & $4,16 \%$ & $12,19 \%$ \\
\hline S3 & Alimentação 3 & & 10.000 & 0 & 1.001 & & & & & \\
\hline M6 & Controlar & 576.014 & & & & $66,67 \%$ & $0,00 \%$ & $0,00 \%$ & $4,16 \%$ & $29,17 \%$ \\
\hline S4 & Alimentação 4 & & 10.000 & 0 & 1.001 & & & & & \\
\hline M7 & Recozer & 575.014 & & & & $76,54 \%$ & $0,00 \%$ & $0,00 \%$ & $2,08 \%$ & $21,38 \%$ \\
\hline Buffer_3 & Buffer & & 60.000 & 10.000 & 22.588 & & & & & \\
\hline M8 & Espoletar & 575.012 & & & & $83,19 \%$ & $0,00 \%$ & $0,00 \%$ & $4,17 \%$ & $12,64 \%$ \\
\hline Buffer_4 & Buffer & & 60.000 & 10.000 & 22.588 & & & & & \\
\hline M9 & Carregar & 575.009 & & & & $83,19 \%$ & $0,00 \%$ & $0,78 \%$ & $5,59 \%$ & $10,44 \%$ \\
\hline S5 & Alimentação 5 & & 10.000 & 0 & 10.000 & & & & & \\
\hline M10 & Impermeabilizar & 574.008 & & & & $83,05 \%$ & $0,00 \%$ & $0,00 \%$ & $2,08 \%$ & $14,87 \%$ \\
\hline S6 & Alimentação 6 & & 10.000 & 0 & 10.002 & & & & & \\
\hline M11 & Controlar & 573.006 & & & & $82,90 \%$ & $0,00 \%$ & $0,00 \%$ & $2,08 \%$ & $15,02 \%$ \\
\hline
\end{tabular}

Fonte: Autor (2018). 
Tabela 21 - Consumo de energia em estado de máquina referente à simulação do cenário D.

\begin{tabular}{|c|c|c|c|c|c|c|c|c|c|c|}
\hline \multirow[t]{2}{*}{ Estação } & \multirow[t]{2}{*}{ Processo } & \multirow{2}{*}{$\begin{array}{c}\text { Consumo Total } \\
\text { (kWh) }\end{array}$} & \multicolumn{2}{|c|}{$\begin{array}{c}\text { Consumo Estado } \\
\text { Processamento }\end{array}$} & \multicolumn{2}{|c|}{$\begin{array}{c}\text { Consumo Estado } \\
\text { Operacional }\end{array}$} & \multicolumn{2}{|c|}{$\begin{array}{l}\text { Consumo Estado } \\
\text { Manutenção }\end{array}$} & \multicolumn{2}{|c|}{$\begin{array}{c}\text { Consumo Estado } \\
\text { Standby }\end{array}$} \\
\hline & & & (\%) & (kWh) & $(\%)$ & $(k W h)$ & (\%) & (kWh) & $(\%)$ & $(\mathrm{kWh})$ \\
\hline M1 & Estirar e cortar & $1.007,60$ & $98,29 \%$ & 990,37 & $0,00 \%$ & 0,00 & $1,71 \%$ & 17,23 & $0,00 \%$ & 0,00 \\
\hline $\mathrm{S} 1$ & Alimentação 1 & & & & & & & & & \\
\hline M2 & Lavar e recozer & $1.933,90$ & $96,66 \%$ & $1.869,31$ & $0,00 \%$ & 0,00 & $1,93 \%$ & 37,32 & $1,41 \%$ & 27,27 \\
\hline \multicolumn{11}{|c|}{ Buffer_1 Buffer } \\
\hline M3 & Conificar & 729,16 & $97,95 \%$ & 714,21 & $0,00 \%$ & 0,00 & $1,76 \%$ & 12,83 & $0,30 \%$ & 2,19 \\
\hline $\mathrm{S} 2$ & Alimentação 2 & & & & & & & & & \\
\hline M4 & Lavar & 331,12 & $95,60 \%$ & 316,55 & $0,00 \%$ & 0,00 & $2,07 \%$ & 6,85 & $2,33 \%$ & 7,72 \\
\hline \multicolumn{11}{|c|}{ Buffer_2 Buffer } \\
\hline M5 & Tornear & 247,96 & $96,64 \%$ & 239,63 & $0,00 \%$ & 0,00 & $1,93 \%$ & 4,79 & $1,43 \%$ & 3,55 \\
\hline $\mathrm{S} 3$ & Alimentação 3 & & & & & & & & & \\
\hline M6 & Controlar & 113,84 & $93,61 \%$ & 106,57 & $0,00 \%$ & 0,00 & $2,34 \%$ & 2,66 & $4,06 \%$ & 4,62 \\
\hline $\mathrm{S} 4$ & Alimentação 4 & & & & & & & & & \\
\hline M7 & Recozer & 700,42 & $95,51 \%$ & 668,97 & $0,00 \%$ & 0,00 & $2,08 \%$ & 14,57 & $2,41 \%$ & 16,88 \\
\hline Buffer_3 & Buffer & & & & & & & & & 0,00 \\
\hline M8 & Espoletar & 182,71 & $96,60 \%$ & 176,50 & $0,00 \%$ & 0,00 & $1,94 \%$ & 3,54 & $1,46 \%$ & 2,67 \\
\hline \multicolumn{11}{|c|}{ Buffer_4 Buffer } \\
\hline M9 & Carregar & 150,61 & $98,89 \%$ & 148,94 & $0,37 \%$ & 0,56 & $0,74 \%$ & 1,11 & $0,00 \%$ & 0,00 \\
\hline S5 & Alimentação 5 & & & & & & & & & \\
\hline M10 & Impermeabilizar & 86,72 & $96,53 \%$ & 83,71 & $0,07 \%$ & 0,06 & $1,94 \%$ & 1,68 & $1,47 \%$ & 1,27 \\
\hline S6 & Alimentação 6 & & & & & & & & & \\
\hline M11 & Controlar & 75,47 & $96,48 \%$ & 72,81 & $0,13 \%$ & 0,10 & $1,93 \%$ & 1,46 & $1,45 \%$ & 1,09 \\
\hline & & $\mathbf{5 . 5 5 9 , 5 1}$ & $96,91 \%$ & $\mathbf{5 . 3 8 7 , 5 7}$ & $0,01 \%$ & 0,72 & $1,87 \%$ & 104,06 & $1,21 \%$ & 67,26 \\
\hline
\end{tabular}

Fonte: Autor (2018).

Figura 27 - Gráfico de consumo de energia referente à simulação do cenário D.

Consumo de Energia

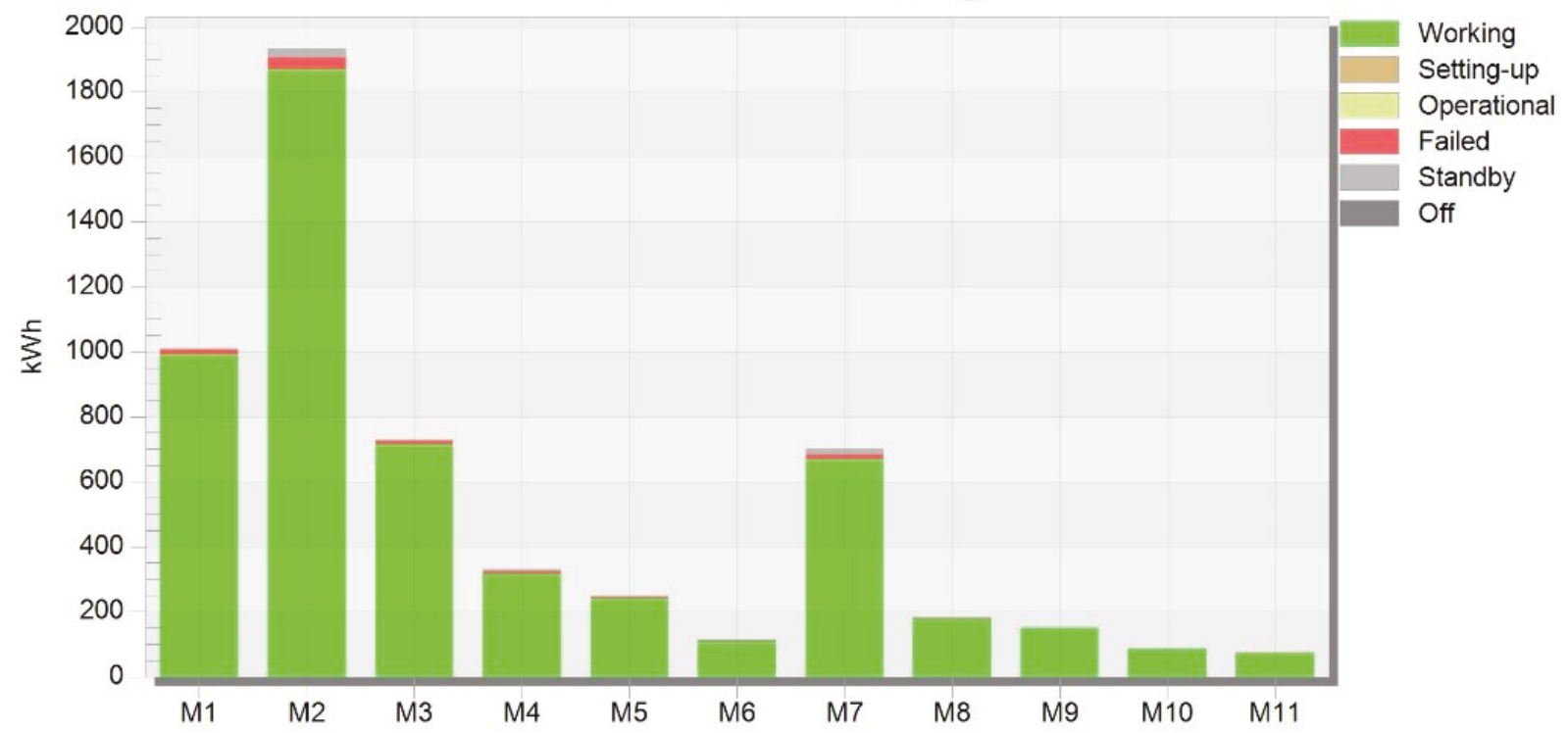

Fonte: Autor (2018). 
Figura 28 - Quantidade de unidades nos buffers durante a simulação do cenário D.

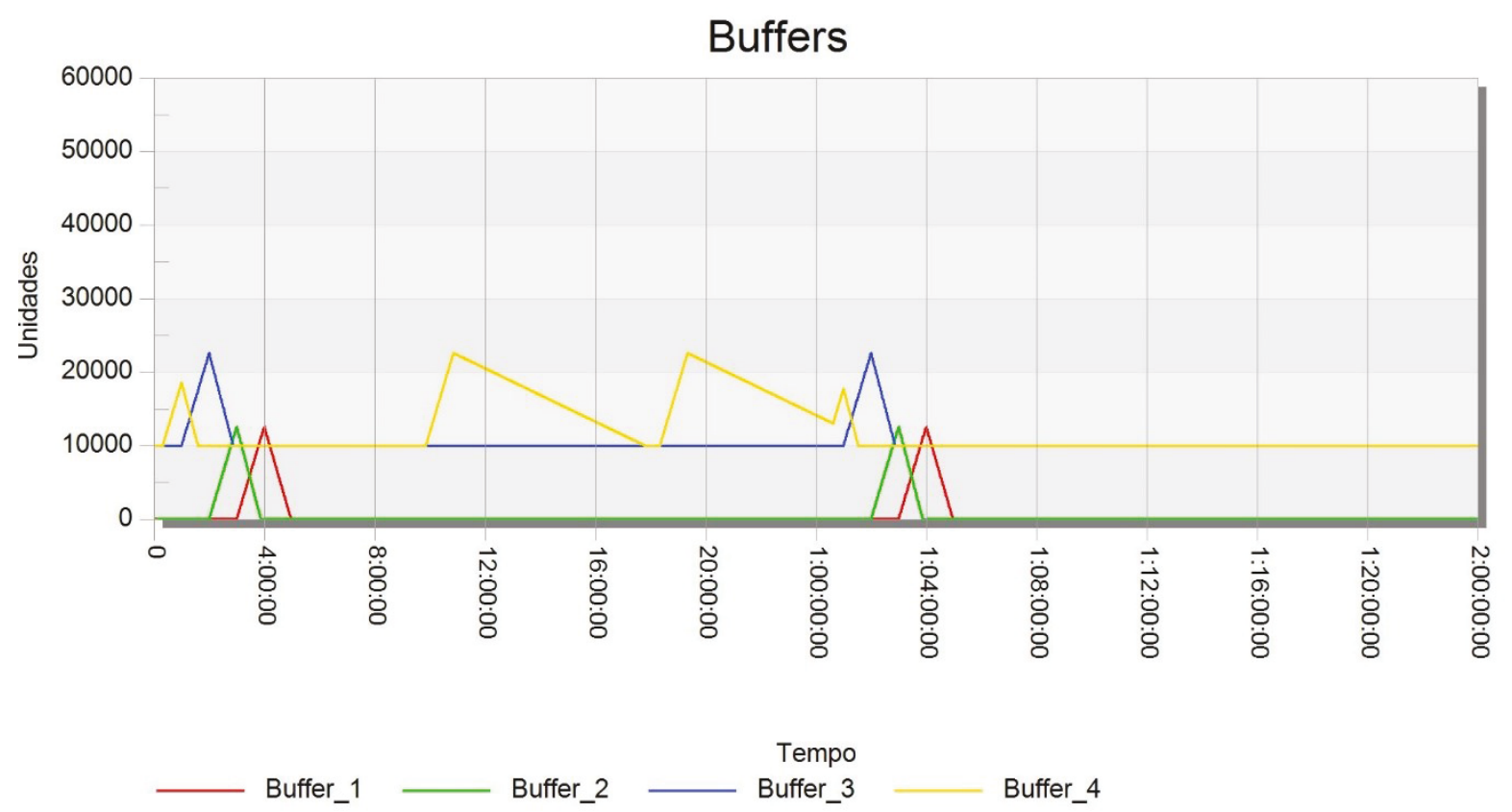

Fonte: Autor (2018).

Figura 29 - Quantidade de unidades nos sistemas de alimentação durante a simulação do cenário D.

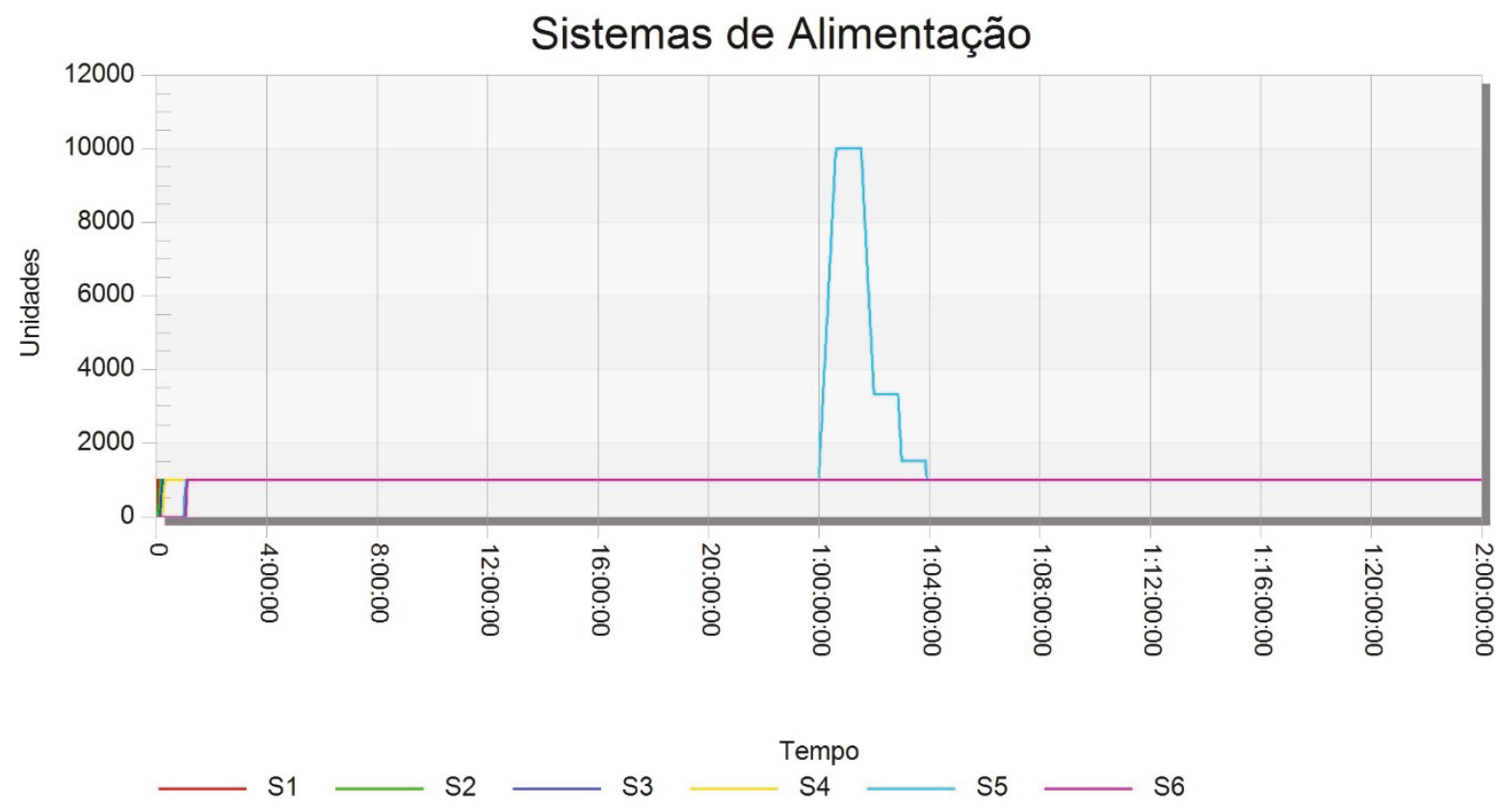

Fonte: Autor (2018). 


\subsection{PRODUTIVIDADE}

A produtividade deste sistema de manufatura de ciclos curtos, de acordo com a empresa, é fundamental para garantir a competitividade no segmento em que atua. Sendo assim, avaliar este quesito é de extrema importância para identificar se as regras de programação utilizadas nos cenários são efetivas para o incremento deste parâmetro. A Tabela 22 apresenta os dados de unidades produzidas em cada cenário.

Tabela 22 - Unidades produzidas em cada cenário.

\begin{tabular}{|c|c|c|c|c|c|}
\hline \multirow{2}{*}{ Estação } & \multirow{2}{*}{ Processo } & Cenário A & Cenário B & Cenário C & Cenário D \\
\hline & & \multicolumn{4}{|c|}{ Unidades Produzidas } \\
\hline M1 & Estirar e cortar & 604.195 & 510.939 & 536.112 & 579.020 \\
\hline M2 & Lavar e recozer & 604.194 & 510.937 & 535.110 & 578.020 \\
\hline M3 & Conificar & 604.193 & 513.936 & 535.108 & 578.017 \\
\hline M4 & Lavar & 604.192 & 510.935 & 534.108 & 577.017 \\
\hline M5 & Tornear & 604.190 & 510.933 & 534.105 & 577.014 \\
\hline M6 & Controlar & 604.189 & 510.933 & 533.106 & 576.014 \\
\hline M7 & Recozer & 604.189 & 510.932 & 532.106 & 575.014 \\
\hline M8 & Espoletar & 614.187 & 520.930 & 532.104 & 575.012 \\
\hline M9 & Carregar & 624.185 & 527.930 & 532.102 & 575.009 \\
\hline M10 & Impermeabilizar & 624.183 & 527.928 & 531.101 & 574.008 \\
\hline M11 & Controlar & 624.182 & 527.926 & 524.570 & 573.006 \\
\hline
\end{tabular}

Fonte: Autor (2018).

Neste quesito, o cenário A serve como base analítica do cenário ideal sem nenhuma ocorrência de paradas aleatórias, sendo apenas impactado pelo desbalanceamento dos tempos de ciclos de cada uma das estações do sistema de manufatura e como observado no gráfico de buffers, não há impacto relevante da utilização de buffers neste cenário. Desta forma, o cenário B será utilizado como referente efetivo de comparação, uma vez que este é o cenário base identificado pelos gestores da empresa que participaram deste estudo. Ao analisar os dados de unidades produzidas pelo sistema, pode-se identificar que houve alterações significativas de produção entre os cenários $\mathrm{C}$ e $\mathrm{D}$, outro aspecto relevante é a importância dos buffers neste cenário, sendo que os mesmos são utilizados quando há as ocorrências de falhas, que podem ser observadas pelos picos, que representam as falhas nos processos posteriores aos buffers e os vales, que representam as falhas nos processos anteriores aos buffers, no cenário B ocorreram picos acima de 40.000 unidades e todos os buffers em algum momento durante a simulação operaram em fluxo continuo, passando as peças diretamente para as estações de trabalho e em determinados momentos ficaram ociosos, impactando as estações de trabalho subsequentes. 
O cenário C comparado ao cenário B mostrou uma redução de 3.356 unidades $(0,64 \%)$, isso ocorreu devido à implementação das regras de programação que em algum período da simulação foram ativadas para mudar o estado de máquina das estações, com o objetivo de reduzir o consumo energético, consequentemente, reduzindo assim a quantidade de peças produzidas no sistema. Além disso, ao avaliar os gráficos de buffers, pode-se identificar uma melhora na estabilidade no que se diz respeito a quantidade de unidades, porém, o Buffer_2 operou grande parte do tempo em fluxo continuo ou em estado ocioso impactando estações de trabalho subsequentes, outra avaliação importante, está na utilização dos sistema de alimentação, no gráfico apresentado, nota-se que as regras de programação para gerenciamento dos estados de máquinas contribuíram para reduzir as oscilações dos materiais em fluxo no sistema, o que de acordo com os gestores da empresa, esta contribuição tem um nível elevado de importância, uma vez que sem este fluxo na linha, qualquer ocorrência de paradas no sistema, podem gerar perdas de produtividade, logo, entende-se que a redução no número de unidades produzidas neste cenário pela última estação, não é relevante, pois, o sistema estava abastecido entre as estações de trabalho.

Diferentemente do cenário $\mathrm{C}$, o cenário $\mathrm{D}$ apresentou um aumento significativo na quantidade de unidades produzidas pelo sistema, 45.080 unidades (8,55\%). Isso mostra que a combinação das regras de programação para gerenciamento dos estados de máquina através do controle de unidades nos buffers e sistema de alimentação em conjunto com as regras de planejamento de paradas de manutenção, incrementaram de forma positiva, o sistema de manufatura.

Neste cenário fica ainda mais evidente que a utilização das regras de programação contribuiu de forma expressiva para a estabilização do sistema de manufatura, os picos e vales foram efetivamente reduzidos, os buffers operaram grande parte do tempo em fluxo continuo devido ao planejamento diário das paradas de manutenção, possibilitando assim, um incremento na quantidade de unidades produzidas pelo sistema, esta situação também ocorreu com os sistemas de alimentação, com exceção do S5 que apresentou uma oscilação positiva na quantidade de unidades devido a parada planejada da estação M10. Outro ponto a se considerar e apontado pelos gestores da empresa, o sistema de manufatura preferencialmente devem operar com os Buffer_3 e Buffer_4 com 10.000 unidades para melhorar a performance do produto, porém, em grande parte do tempo, isso não é obedecido pela empresa devido a dificuldade de estabilizar os fluxos de materiais entre as estações.

De forma complementar, outra avaliação importante entre os cenários são os tempos em cada estado que as estações de trabalho estavam durante o período da simulação em função da 
quantidade de unidades produzidas, a Figura 30 apresenta as informações consolidados por cenário e traz o detalhamento em sua tabela de dados.

Figura 30 - Gráfico de produção versus estados de máquina por cenário.

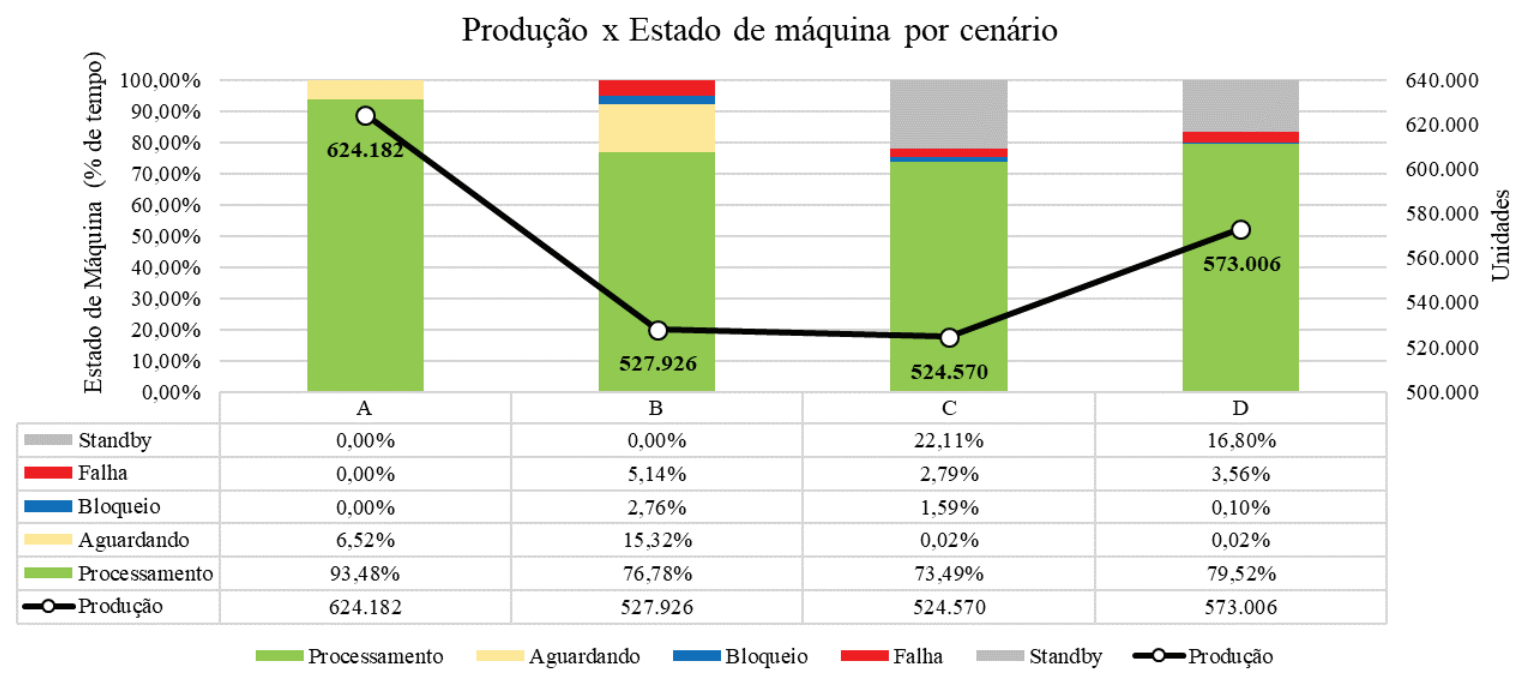

Fonte: Autor (2018).

O cenário A apresenta apenas percentuais em "processamento" e "aguardando", devido ao desbalanceamento dos tempos de ciclos das estações do sistema de manufatura. Além disso, os tempos em "falha" e "standby" não apresentam valores devido à não ocorrências de paradas não-planejadas e pela ausência de regras de programação para gerenciamento dos estados de máquinas.

Por outro lado, ao avaliar os dados do cenário B, pode-se identificar uma redução significativa no tempo de "processamento", o que justifica a redução da quantidade de unidades produzidas em comparação ao cenário A, esta alteração tem como fator principal a ocorrência de paradas não-planejadas neste cenário, que pode ser identificada no aumento do tempo em "falha".

A utilização das regras de programação no cenário C pode ser avaliada pela migração do tempo "aguardando" para o tempo em "standby", por outro lado, em função do consumo energético, as regras de programação reduziram o tempo em processamento, o que gerou impacto negativo na quantidade de unidades produzidas, conforme discutido acima.

O planejamento de paradas de manutenção através das regras de programação demonstrou que houve aumento no tempo de "processamento" em comparação ao cenário B, bem como a redução do tempo de "standby", o que gerou o aumento da quantidade de unidades 
produzidas e, consequentemente, o aumento de eficiência neste parâmetro, mesmo gerando um aumento no tempo em "falha".

Desta forma, pode-se identificar que a combinação das regras de programação para gerenciamento de estados de máquinas através do controle da quantidade de peças dos buffers e sistemas de alimentação pode gerar efeito positivo no quesito eficiência energética. No entanto, inicialmente, para sistemas de manufatura de ciclos curtos, o impacto em produtividade apresentou variação negativa, por outro lado, ao ser combinado com regras de programação de planejamento de paradas de manutenção demonstrou um impacto positivo em produtividade, uma vez que os equipamentos não entram em estado de falha aleatoriamente, evitando, assim, que estações de trabalho fiquem bloqueadas ou aguardando peças.

\subsection{CONSUMO ENERGÉTICO}

No que tange ao comportamento energético do sistema de manufatura, este parâmetro está em evidência pela empresa por representar, em termos financeiros, aproximadamente 20\% de sua folha de pagamento. Sendo assim, além do fator de produtividade, o sistema de manufatura passa a ser avaliado através de indicadores de eficiência energética, como o Lean Energy Indicador (LEI) e pelo Consumo de Energia Unitário (CEU). A Tabela 23 apresenta as informações relevantes sobre este parâmetro, além disso, vale ressaltar que as unidades que iniciam no sistema no Buffer_3 e Buffer_4 consumiram uma quantidade de energia uma vez que estão presentes no sistema. Este consumo não será considerado para avaliação dos resultados deste trabalho, pois nos quatro cenários o parâmetro se mantém inalterado. Porém, os consumos de energia estimados baseados no CEU de cada cenário para as 20.000 unidades presentes no sistemas no momento inicial são de 112,34 KWh no cenário A, 120,21 KWh no cenário $\mathrm{B}, 114,17 \mathrm{KWh}$ no cenário C e $110,52 \mathrm{KWh}$ no cenário D. 
Tabela 23 - Dados de consumo de energia e indicadores de eficiência energética.

\begin{tabular}{clcccc} 
& & Cenário A & Cenário B & Cenário C & Cenário D \\
Estação & & & \multicolumn{2}{c}{ Consumo de Energia (kWh) } \\
& & $1.033,44$ & 937,72 & 963,56 & $1.007,60$ \\
\hline M1 & Estirar e cortar & $2.235,36$ & $2.028,37$ & $1.819,59$ & $1.933,90$ \\
\hline M2 & Lavar e recozer & 755,11 & 685,97 & 701,31 & 729,16 \\
\hline M3 & Conificar & 363,05 & 332,35 & 306,31 & 331,12 \\
\hline M4 & Lavar & 287,04 & 253,41 & 235,54 & 247,96 \\
\hline M5 & Tornear & 130,97 & 120,61 & 109,19 & 113,84 \\
\hline M6 & Controlar & 771,44 & 706,38 & 659,44 & 700,42 \\
\hline M7 & Recozer & 212,16 & 187,24 & 171,64 & 182,71 \\
\hline M8 & Espoletar & 179,04 & 154,42 & 139,84 & 150,61 \\
\hline M9 & Carregar & 100,80 & 88,08 & 80,98 & 86,72 \\
\hline M10 & Impermeabilizar & 87,84 & 76,74 & 69,75 & 75,47 \\
\hline M11 & Controlar & $\mathbf{6 . 1 5 6 , 2 5}$ & $\mathbf{5 . 5 7 1 , 2 9}$ & $\mathbf{5 . 2 5 7 , 1 5}$ & $\mathbf{5 . 5 5 9 , 5 1}$ \\
\hline Consumo Total & & & &
\end{tabular}

\begin{tabular}{|c|c|c|c|c|c|}
\hline \multicolumn{6}{|c|}{ Consumo de energia por estado de máquina } \\
\hline \multirow{2}{*}{ Processamento } & $(\%)$ & $97,92 \%$ & $90,77 \%$ & $94,85 \%$ & $96,91 \%$ \\
\hline & $\mathrm{kWh}$ & $6.028,35$ & $5.056,90$ & $4.986,57$ & $5.387,57$ \\
\hline \multirow{2}{*}{ Operacional } & $(\%)$ & $2,08 \%$ & $6,23 \%$ & $0,32 \%$ & $0,01 \%$ \\
\hline & $\mathrm{kWh}$ & 127,90 & 346,89 & 16,61 & 0,72 \\
\hline \multirow{2}{*}{ Manutenção } & $(\%)$ & \multirow{2}{*}{ NA } & $3,01 \%$ & $3,19 \%$ & $1,87 \%$ \\
\hline & $\mathrm{kWh}$ & & 167,54 & 167,50 & 104,06 \\
\hline \multirow{2}{*}{ Standby } & $(\%)$ & \multirow{2}{*}{ NA } & \multirow{2}{*}{ NA } & $1,64 \%$ & $1,21 \%$ \\
\hline & $\mathrm{kWh}$ & & & 86,47 & 67,26 \\
\hline Produção & UN. & 624.182 & 527.926 & 524.570 & 573.006 \\
\hline LEI & Fator & 0,9792 & 0,9077 & 0,9485 & 0,9691 \\
\hline CEU & $\mathrm{kWh} / \mathrm{UN}$. & 0,0099 & 0,0106 & 0,0100 & 0,0097 \\
\hline
\end{tabular}

Fonte: Autor (2018).

Preliminarmente, o cenário A considerado como "cenário ideal", apresentou um fator de eficiência no consumo de energia (LEI) de 0,9792, ficando extremamente próximo do fator ideal (1), sendo a diferença devido às variações de tempo de ciclo dos equipamentos que ocasionaram tempo de espera em algumas máquinas. Quanto ao consumo de energia unitário (CEU), este cenário apresentou o resultado de $0,0099 \mathrm{kWh} /$ unidade.

Entretanto, o cenário B, considerado como "cenário atual" da empresa, apresentou fatores muito abaixo em comparação ao cenário A. O fator LEI reduziu para 0,9077 , ficando 0,0933 abaixo do fator ideal (1) e 0,0716 do fator obtido no cenário A, o que demonstra que há oportunidades para melhorar a eficiência energética do sistema de manufatura. Deste modo, 
com a redução da eficiência energética, o CEU passou para $0,0106 \mathrm{kWh} /$ unidade, representando um aumento $7 \%$ em comparação ao cenário A.

As regras de programação utilizadas no cenário $\mathrm{C}$ apresentaram resultados positivos no aspecto de eficiência energético. O fator LEI aumentou para 0,9485, ficando 0,0307 abaixo em comparação ao cenário A, que adotamos como "ideal", e 0,0408 maior do que o cenário B, ficando abaixo 0,0515 do fator ideal (1). Porém, o CEU, em comparação com o cenário B, melhorou em 5,02\% devido ao ganho de eficiência energética. Desta forma, destaca-se que o gerenciamento dos estados de máquina através do controle de unidades nos buffers e nos sistemas de alimentação geraram um impacto relevante para os resultados de eficiência energética.

Por fim, o cenário D mostrou que novamente a combinação das regras de programação geraram resultados positivos não apenas nos aspectos de produtividade, mas também na eficiência energética do sistema de manufatura. O fator LEI aumentou para 0,9691, ficando 0,0101 abaixo em comparação ao cenário A, que foi adotado como "ideal”, e 0,0206 maior do que o cenário $\mathrm{C}$, ficando abaixo apenas 0,0309 do fator ideal (1). Porém, o CEU melhorou $3,19 \%$ em comparação ao cenário C e 1,62\% em comparação ao cenário A, devido ao ganho de eficiência energética e de produtividade. Desta forma, destaca-se que o gerenciamento dos estados de máquina através do controle de unidades nos buffers e nos sistemas de alimentação combinados ao planejamento de paradas de manutenção potencializam os resultados de eficiência energética, pois conseguem melhorar o consumo de energia nas estações de trabalho e, ao mesmo tempo, aumentar a produtividade do sistema de manufatura. A Figura 31 apresenta de forma consolidada os resultados obtidos nas análises entre os cenários referentes ao consumo de energia por estado de máquina.

Figura 31 - Gráfico de consumo de energia por estado de máquina em cada cenário.

Consumo de energia por estado de máquina

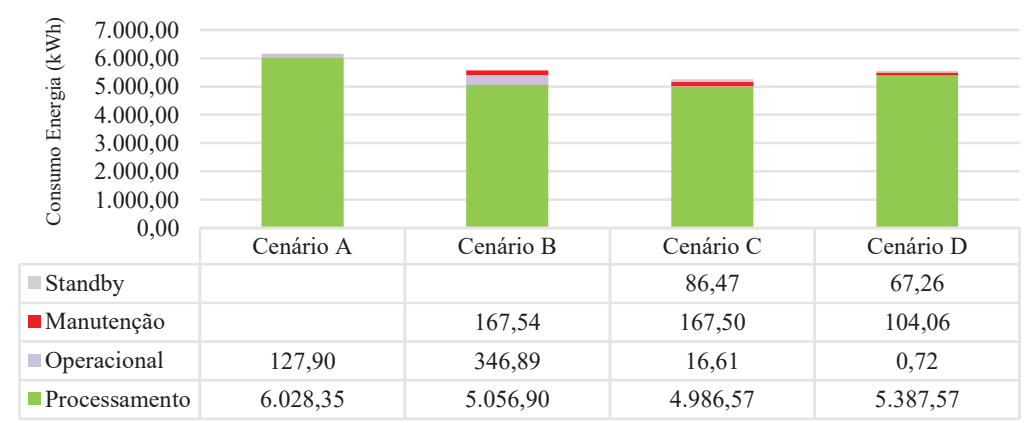

Fonte: Autor (2018). 
A Figura 32, por sua vez, apresenta a evolução dos indicadores de eficiência energética LEI e CEU para cada um dos cenários.

Figura 32 - Resultado das análises realizadas nos cenários avaliados.

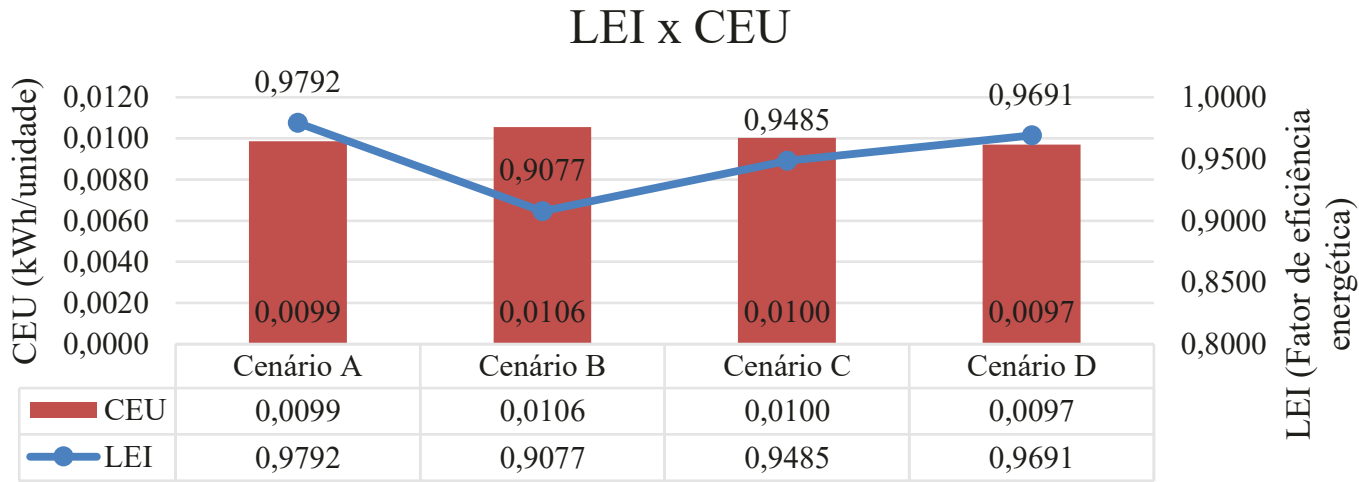

Fonte: Autor (2018).

Com base nos dados de eficiência energética apresentados, pode-se identificar que diferente do que ocorreu no aspecto de produtividade, as regras de programação do cenário C contribuíram de forma expressiva para o aumento da eficiência energética em comparação ao cenário B. Além disso, a adição da regra de planejamento de paradas de manutenção contribuiu também de forma incremental para o aumento da eficiência, obtendo inclusive um CEU melhor que o obtido no cenário A, o qual fora definido como o cenário "ideal” neste aspecto.

\subsection{AVALIAÇÃO GERAL DOS RESULTADOS}

Complementar ao estudo de eficiência energética, outro aspecto de suma importância a ser explorado é a avalição econômica do modelo, uma vez que as ações realizadas nos estudos necessitaram de investimento para que a empresa as implemente. Sendo assim, a empresa informou apenas os dados básicos de custo por $\mathrm{kWh}$ atual e o valor de margem de cada unidade vendida desta linha, o Tabela 24 apresenta as avaliações financeiras de cada cenário. 
Tabela 24 - Eficiência energética e avaliação financeira dos cenários.

\begin{tabular}{|c|c|c|c|c|c|}
\hline & & Cenário A & Cenário B & Cenário C & Cenário D \\
\hline Produtividade & Unidades & 624.182 & 527.926 & 524.570 & 573.006 \\
\hline LEI & Fator & 0,9792 & 0,9077 & 0,9485 & 0,9691 \\
\hline CEU & $\mathrm{kWh} / \mathrm{UN}$. & 0,0099 & 0,0106 & 0,0100 & 0,0097 \\
\hline Custo Total de Energia (Tarifa Empresa $=$ RS 0,5697/kWh) & $\mathrm{R} \$$ & $3.506,18$ & $3.173,01$ & $2.994,45$ & $3.166,48$ \\
\hline Margem de Contribuição (Margem Média = RS 0,076/UN.) & $\mathrm{R} \$$ & $47.437,83$ & $40.122,38$ & $39.867,32$ & $43.548,46$ \\
\hline Resultado (Margem - Custo de Energia) & $\mathrm{RS}$ & $43.931,65$ & $36.949,36$ & $36.872,87$ & $40.381,97$ \\
\hline
\end{tabular}

Fonte: Autor (2018).

Os resultados comparativos de custos versus margem nos direcionam para decisões importantes, desta forma, utilizamos como base de comparação para os cenários $\mathrm{C}$ e $\mathrm{D}$, o cenário $\mathrm{B}$, por ser o cenário que representa a situação atual da empresa. Ao avaliar o cenário $\mathrm{C}$, nota-se que, após a implementação do gerenciamento dos estados de máquinas através das regras de programação, o mesmo apresentou uma redução de 5,63\% no custo de energia elétrica em função da produção quando comparado ao cenário B. Entretanto, devido à redução do volume de produção, impactado pelas ocorrências de paradas não-planejadas, a margem de contribuição reduziu em $0,66 \%$. Ao realizarmos a consolidação da redução do custo de energia com a perda de margem, identifica-se que apesar do cenário $\mathrm{C}$ apresentar melhor eficiência energética em comparação com o cenário $\mathrm{B}$, há uma perda de $0,21 \%$ no resultado para a empresa.

A comparação dos resultados do cenário D com o cenário $\mathrm{B}$, por sua vez, apresentaram pontos de melhoria após a combinação do gerenciamento dos estados de máquinas através das regras de programação e do planejamento de paradas diárias de manutenção. O custo de energia elétrica reduziu $0,21 \%$, a margem de contribuição obteve um incremento importante de 8,54\% oriundo do aumento de disponibilidade devido ao planejamento de paradas diárias de manutenção. Nesta esteira, ao realizar-se a consolidação da redução do custo de energia com o ganho de margem, identifica-se que a combinação das ações propostas no cenário D representou uma melhora significativa de eficiência energética, além disso, houve um aumento significativo no resultado financeiro para a empresa de $9,29 \%$.

De maneira geral, os resultados apresentados mostram que as regras de programações para gerenciamento dos estados de máquinas e o planejamento diário de paradas proporcionaram resultados positivos, principalmente no cenário $\mathrm{D}$, quando ambas estão integradas ao sistema. Esta análise contribui para validar a contribuição destes conceitos em um sistema de manufatura com processos de ciclos curtos, até então, pouco explorados. 


\section{CONCLUSÕES}

A busca pela eficiência energética vem se tornando cada vez mais relevante para a sociedade, as empresas e para a comunidade acadêmica devido aos novos acordos políticos, legislações mais restritivas, fatores ambientais, financeiros e pela própria demanda da sociedade no âmbito global. No cenário brasileiro, há outros fatores que contribuem para o fomento deste tema, a geração de energia no Brasil é realizada em sua grande parte por hidrelétricas, que podem sofrer perdas de produtividade relevantes ocasionada pela falta de chuvas e redução dos níveis dos sistemas hídricos nacionais. Nos últimos cinco anos, os sistemas hídricos sofreram grandes variações em seus níveis, o que elevou a pressão sobre as tarifas de energia elétrica, bem como a criação de cobranças adicionais como a regra das bandeiras tarifárias. Desta forma, este tema demonstra ser relevante para a sociedade, bem como contribui com a evolução das indústrias e a utilização dos conceitos de eficiência energética como aspecto de sustentabilidade e competitividade.

Através dos estudos de simulação foram estabelecidos e calculados indicadores de eficiência energética, cuja utilização permite um comparativo da eficácia dentre as diferentes ações sugeridas. Para identificar as oportunidades e avaliar os conceitos, quatro cenários foram avaliados neste estudo. Os resultados analisados atingiram os objetivos deste estudo e demonstraram ainda que a simulação de diferentes cenários permite não apenas a obtenção de um diagnóstico efetivo da situação atual do sistema de manufatura, como também possibilita a identificação das oportunidades de eficiência energética e produtividade para melhorar o uso dos recursos disponíveis ou suportar projetos de investimentos.

Adicionalmente, a utilização das regras de programação para gerenciamento dos estados de máquinas através do controle de unidades nos buffers e nos sistemas de alimentação contribuiu de forma relevante para a eficiência energética, e, quando combinada com a regra de programação de paradas planejadas diárias de manutenção, os aspectos de produtividade foram superiores ao cenário atual da empresa e aumentaram significativamente os resultados de eficiência energética atingidos no cenário anterior. Além disso, a contribuição efetiva deste estudo está na verificação dos conceitos apresentados por diversos autores, porém, em um sistema de manufatura com processos de ciclos curtos, cujo o qual, possui aspectos peculiares e pouco discutidos até o momento.

Desta forma, o que pode-se identificar que para este tipo de sistema de manufatura desta empresa em estudo, de acordo com os resultados, a simples utilização das regras de programação para gerenciamento dos estados de máquina de acordo com a quantidade de 
unidades nos buffers e sistema de alimentação, podem contribuir de forma positiva para os aspectos de eficiência energética. Porém, devido aos curtos ciclos dos processos, em determinadas ocasiões, estas regras podem reduzir o volume de peças produzidas e impactar negativamente nos aspectos financeiros.

Por outro lado, o que fora identificado neste sistema, é a alta relevância para as ocorrências de paradas não planejadas, a junção das regras de gerenciamento dos estados de máquinas em conjunto com um planejamento diário de manutenções, apresentou de acordo com os modelos avaliados, um aumento significativo no resultado de produtividade, contribuindo assim para uma melhor eficiência energética e gerando um resultado positivo no que se refere aos aspectos financeiros. Sendo assim, este sistema em estudo, necessita de uma estratégia hibrida que vise a eficiência energética e que mantenha como foco a produtividade do sistema.

De maneira completar, os objetivos específicos de apresentar os conceitos da indústria 4.0 com foco em manufatura digital para realizar análises de consumo de energia nos sistemas de produção, identificar regras de programação que auxiliam na redução do consumo de energia em sistemas de manufatura de ciclos curtos, investigar as oportunidades para redução do consumo de energia e contribuir com o setor empresarial apontando lacunas no uso racional de energia elétrica foram atingidos ao longo deste trabalho, o que pode ser constatado quer na discussão dos conceitos utilizados quer nos resultados obtidos e analisados.

Durante a realização deste estudo, a coleta dos dados de consumo de energia dos equipamentos em campo, bem como algumas informações relevantes para o estudo tiveram de ser realizadas por técnicos e gestores de forma presencial, uma vez que no segmento em que a empresa atua, o aspecto de eficiência energética não exerce papel prioritário; sendo assim, a obtenção e tabulação dos dados foi uma das dificuldades encontradas. Além disso, a singularidade do sistema de manufatura abordado neste estudo representou uma das maiores dificuldades devido à falta de informações de sistemas similares para comparação ou suporte.

Por fim, o estudo apresentado não leva em conta as atividades que devem ser realizadas pelos operadores, ou ainda o consumo de energia nos horários de ponta, ou seja, há o mesmo tratamento para os dados de consumo e demanda de potência elétrica, independentemente da hora do dia - ponta ou fora de ponta. Desta forma, propõe-se o desenvolvimento de trabalhos futuros que avaliem as oportunidades não apenas do gerenciamento dos estados de máquina, mas a operação, considerando-se as atividades necessárias dos operadores no processo para identificar oportunidades de aumento de produtividade, uma vez que este fator tem peso relevante para este sistema de manufatura com processos de ciclos curtos. Nesse meandro, no que se refere ao consumo de energia nos horários de ponta, uma oportunidade está na análise 
geral do consumo energético em função do custo para todos os sistemas de manufatura desta empresa, uma vez que ela possui uma usina de energia dimensionada para suportar sua operação de forma ininterrupta. Outra abordagem relevante para ampliar as análises deste estudo está na ampliação do escopo de um sistema de manufatura para uma planta industrial, a qual aumenta a complexidade das variáveis de produção, gargalos e logísticas internas de distribuição e movimentação. 


\section{REFERÊNCIAS}

ABELE, E.; BRAUN, S.; SCHRAML, P. Holistic Simulation Environment for Energy Consumption Prediction of Machine Tools. Procedia CIRP, p. 251-256, 2015.

ABELE, E.; PANTEN, N.; MENZ, B. Data Collection for Energy Monitoring Purposes and Energy Control of Production Machines. Procedia CIRP, p. 299-304, 2015.

ACATECH. Recommendations for implementing the strategic initiative INDUSTRIE 4.0, $2013 . \quad$ Disponível em: $<$ http://www.acatech.de/fileadmin/user_upload/Baumstruktur_nach_Website/Acatech/root/de/ Material_fuer_Sonderseiten/Industrie_4.0/Final_report_Industrie_4.0_accessible.pdf $>$

ACATECH. Industrie 4.0 Maturity Index - Managing the Digital Transformation of Companies, 2017. Disponível em: $<$ http://www.acatech.de/fileadmin/user_upload/Baumstruktur_nach_Website/Acatech/root/de/ Publikationen/Projektberichte/acatech_STUDIE_Maturity_Index_eng_WEB.pdf>

AES ELETROPAULO. Bandeiras Tarifárias, 2017. Disponível em: $<$ https://www.aeseletropaulo.com.br/educacao-legislacaoseguranca/informacoes/Paginas/bandeiras-tarifarias.aspx>. Acesso em: 2 out. 2017

ANDERSON, S. T.; NEWELL, R. G. Information programs for technology adoption: the case of energy-efficiency audits. Resource and Energy Economics, p. 27-50, 2004.

ANEEL. Bandeiras Tarifárias, 2017. Disponível em: <http://www.aneel.gov.br/sala-deimprensa-exibicao/-/asset_publisher/XGPXSqdMFHrE/content/aneel-anuncia-bandeiratarifaria-verde-para-junho/656877?inheritRedirect=false>. Acesso em: 26 set. 2017

ANTONIOL, R. Análise de eficiência energética em sistemas de produção por meio da utilização de ferramentas de manufatura digital. Dissertação (Mestrado em Engenharia Mecânica)—São Bernardo do Campo: Centro Universitário da FEI, 2016.

BANDEIRANTE ENERGIA. Manual de orientação aos consumidores: critérios de contratação e tarifas aplicadas, 2004. Disponível em: $<$ http://www.edp.com.br/distribuicao/edp-escelsa/informacoes/grandes-clientes/normas-emanuais/Documents/Manual\%20de\%20Orienta\%E7\%E3o\%20-

$\% 20$ Crit $\%$ E9rios $\% 20 \mathrm{de} \% 20$ Contrata $\%$ E7\%E3o\%20e\%20Tarifas\%20Aplicadas.pdf $>$. Acesso em: 11 set. 2017

BANKS, J. et al. Discrete-event system simulation. 5. ed. New Jersey: Prentice Hall, 2009.

BENEDETTI, M.; CESAROTTI, V.; INTRONA, V. From energy targets setting to energyaware operations control and back: An advanced methodology for energy efficient manufacturing. Journal of Cleaner Production, p. 1518-1533, 30 set. 2016.

BERGMILLER, G. G.; MCCRIGHT, P. R. Lean Manufacturers' Transcendence to Green Manufacturing. Proceedings of the 2009 Industrial Engineering Research Conference, $p$. $1-6,2009$. 
BRUNKE, J.-C.; JOHANSSON, M.; THOLLANDER, P. Empirical investigation of barriers and drivers to the adoption of energy conservation measures, energy management practices and energy services in the Swedish iron and steel industry. Journal of Cleaner Production, p. 509525, 9 maio 2014.

BUNSE, K. et al. Integrating energy efficiency performance in production management e gap analysis between industrial needs and scientific literature. Journal of Cleaner Production, p. 667-679, 25 nov. 2010.

CÁCERES, M. S. J.; CASTILHO, R. A.; ROSÁRIO, J. M. Proposta metodológica para a formação profissional na área de manufatura digital-PLM. CONGRESSO BRASILEIRO DE ENGENHARIA DE FABRICAÇÃ̃o, p. 19-30, 2011.

CATALDO, A.; SCATTOLINI, R.; TOLIO, T. An energy consumption evaluation methodology for a manufacturing plant. CIRP Journal of Manufacturing Science and Technology, p. 53-61, nov. 2015.

CAUCHICK, M. Metodologia de pesquisa em engenharia de produção e gestão de operações. 2. ed. Rio de Janeiro: Elsevier, 2012.

CHANG, Q. et al. Energy Saving Opportunity Analysis of Automotive Serial Production Systems (March 2012). IEEE TRANSACTIONS ON AUTOMATION SCIENCE AND ENGINEERING, p. 334-342, abr. 2013.

CHRYSSOLOURIS, G. et al. Digital manufacturing: history, perspectives, and outlook. p. 451-462, 20 jun. 2008.

CNI. Matriz energética: cenários, oportunidades e desafios, 2007. Disponível em: $<$ http://admin.cni.org.br/portal/data/pages/FF808081310B1CBB01314F2266E27002.htm>.

Acesso em: 22 set. 2017

DE CARLI, P. C.; DELAMARO, M. C.; SALOMON, V. A. P. Identificação e priorização dos fatores críticos de sucesso na implantação de fábrica digital. Produção, p. 549-564, 2010.

DIAZ, N.; REDELSHEIMER, E.; DORNFELD, D. Energy consumption characterization and reduction strategies for milling machine tool use. In: Hesselbach J., Herrmann C. (eds) Glocalized Solutions for Sustainability in Manufacturing, 7 mar. 2011.

DUFLOU, J. R. et al. Critical comparison of methods to determine the energy input for discrete manufacturing processes. CIRP Annals - Manufacturing Technology, p. 63-66, 2012a.

DUFLOU, J. R. et al. Towards energy and resource efficient manufacturing: A processes and systems approach. CIRP Annals - Manufacturing Technology, p. 587-609, 2012b.

DYER, C. H. et al. Enabling technologies for industrial energy demand management. Energy Policy, p. 4434-4443, 2008.

EIA. Renewable Energy Consumption and Electricity Preliminary Statistics, 2010. Disponível em: <https://www.eia.gov/renewable/annual/preliminary/pdf/preliminary.pdf>. Acesso em: 17 ago. 2017 
ELETROBRAS. Manual de tarifação da energia elétrica, ago. 2011. Disponível em: $<$ http://www.mme.gov.br/documents/10584/1985241/Manual de Tarif En El - Procel_EPP Agosto-2011.pdf>. Acesso em: 21 ago. 2017

EPE. Balanço Energético Nacional 2018, 2018. Disponível em: $<$ http://epe.gov.br/pt/publicacoes-dados-abertos/publicacoes/balanco-energetico-nacional$2018>$

EUROPEAN COMMISSION. Impact Assessment, 2008. Disponível em: $<$ http://ec.europa.eu/transparency/regdoc/rep/2/2008/EN/2-2008-85-EN-1-0.Pdf $>$. Acesso em: 28 jul. 2017

FERNANDEZ, M.; LI, L.; SUN, Z. "Just-for-Peak" buffer inventory for peak electricity demand reduction of manufacturing systems. International Journal of Production Economics, p. 178-184, 2013.

FIRJAN. Quanto custa a energia elétrica para a pequena e média indústria no Brasil?, fev. 2017. Disponível em: <http://www.firjan.com.br/publicacoes/publicacoes-deeconomia/quanto-custa-a-energia-eletrica.htm>

FLEITER, T. et al. Energy efficiency in the German pulp and paper industry - A model-based assessment of saving potentials. Energy, p. 84-99, 2012.

GAMA, E. B. Benefícios obtidos na colaboração entre sistemas MES e sistemas de manufatura digital do PLM - diagnóstico. Dissertação (Mestrado em Engenharia de Produção)—São Carlos: Universidade Federal de São Carlos, 2011.

GAMA, E. B.; COSTA, M. A. Benefícios obtidos com a integração dos sistemas MES e a manufatura digital do PLM. ENCONTRO NACIONAL DE ENGENHARIA DE PRODUÇÃO, p. 31-40, 2009.

GODOI, J. M. A. Eficiência energética industrial: um modelo de governança de energia para a indústria sob requisitos de sustentabilidade. Dissertação (Mestrado em Ciências) São Paulo: Universidade de São Paulo, 2011.

GONZÁLEZ, A. G.; PALACIN, R.; BATTY, P. Optimal energy management of urban rail systems: Key performance indicators. Energy Conversion and Management, p. 282-291, 2015 .

GROOT, H. L.; NIJKAMP, P.; VERHOEF, E. Energy saving by firms: decision making, barriers and polices. Energy Econ., p. $868-888,2001$.

HARREL, C.; GHOSH, B. K.; BOWDEN, R. Simulation using Promodel. 2. ed. New York: McGraw-Hill, 2004.

HARRIS, J.; ANDERSON, J.; SHAFRON, W. Investment in energy efficiency: a survey of Australian firms. Energy Policy, p. 867-876, 2000.

HERRMANN, C. et al. Energy oriented simulation of manufacturing systems - Concept and application. CIRP Annals - Manufacturing Technology, p. 45-48, 2011.

HEWITT, P. S. Depopulation and ageing in europe and japan the hazardous transition to a labor shortage economy. p. 111-120, 2002. 
JAHANGIRIAN, M. et al. Simulation in manufacturing and business: A review. European Journal of Operational Research, p. 1-13, 16 maio 2010.

JOHANSSON, B. et al. Discrete event simulation with lifecycle assessment data at a juice manufacturing system. FOODSIM, p. 1-6, 2008.

JOVANOVIC, V.; HARTMAN, N. W. Web-based virtual learning for digital manufacturing fundamentals for automotive workforce training. International Journal of Continuing Engineering Education and Life Long Learning XIV, p. 300-310, 2013.

LAW, A. M.; KELTON, W. D. Simulation modeling and analysis. 3. ed. New York: McGraw-Hill, 2000.

LAW, A. M.; MACCOMAS, M. G. Simulation of manufacturing systems. Proceedings of the 1997 Winter Simulation Conference, p. 86-89, 1999.

MAY, G. et al. Energy Management in Production: A novel Method to Develop Key Performance Indicators for Improving Energy Efficiency. APPLIED ENERGY, p. 46-61, jul. 2015.

MAY, G. et al. Energy management in manufacturing: From literature review to a conceptual framework. Journal of Cleaner Production, p. 1-26, 2016.

MOREIRA, S. Estratégias de simulação para análise da eficiência energética em sistema de bombeamento monitorado via supervisório. Dissertação (Mestrado em Engenharia Elétrica)—Mato Grosso do Sul: Universidade Federal de Mato Grosso do Sul, 2008.

MOUZON, G.; YILDIRIM, M. B. A Framework to Minimize Total Energy Consumption and Total Tardiness on a Single Machine. International Journal of Sustainable Engineering, p. 105-116, 2008.

REN, T. Barriers and drivers for process innovation in the petrochemical industry: A case study. Journal of Engineering and Technology Management, p. 285-304, 2009.

ROBINSON, S. Discrete-event simulation: from the pioneers to the present, what next? Journal of the Operational Research Society, p. 619-629, 2005.

SAKURADA, N.; MIYAKE, D. Aplicação de simuladores de eventos discretos no processo de modelagem de sistemas de operações de serviços. Gestão \& Produção, p. 25-43, 2009.

SALES, C. Energia, fontes renováveis e etanol, 2008. Disponível em: $<$ http://legis.senado.leg.br/sdleg-getter/documento/download/9655b7ee-4c33-4654-88968ad2eb92e7b7>. Acesso em: 29 jul. 2017

SALONITIS, K.; BALL, K. Energy efficient manufacturing from machine tools to manufacturing systems. Procedia CIRP, p. 634-639, 2013.

SANTOS, D. B. P.; BARBOSA, E. E. F. Manufatura digital no planejamento da automação da usinagem de componentes powertrain. SIMEA, 2015. 
SEOW, Y.; RAHIMIFARD, S. A framework for modeling energy consumption within manufacturing systems. CIRP Journal of Manufacturing Science and Technology, p. 258264, 2011.

SHI, H. et al. Barriers to the implementation of cleaner production in Chinese SMEs: government, industry and expert stakeholders' perspectives. Journal of Cleaner Production, p. 842-852, 2008.

SLANSKY, D. Gaining competitive advantage through digital manufacturing. ARC Insights, p. $1-4,2006$.

SOLDING, P.; PETKU, D. Applying energy aspects on simulation of energy-intensive production systems. WINTER SIMULATION CONFERENCE, p. 1428-1432, 2005.

SOLDING, P.; THOLLANDER, P. Increased energy efficiency in a swedish iron foundry through use of discrete event simulation. WINTER SIMULATION CONFERENCE, p. 1971-1976, 2006.

SPRENG, F.; EBERHARD, P.; FLEISSNER, F. An approach for the coupled simulation of machining processes using multibody system and smoothed particle hydrodynamics algorithms. Theoretical and Applied Mechanics Letters, p. 1-7, 2013.

SUN, Z. Inventory control for peak electricity demand reduction of manufacturing systems considering the tradeoff between production loss and energy savings. Journal of Cleaner Production, p. 84-93, 2014.

SUN, Z.; LI, L. Opportunity estimation for real-time energy control of sustainable manufacturing systems. Automation Science and Engineering, p. 38-44, 2013.

THIEDE, S. et al. Environmental aspects in manufacturing system modelling and simulation State of the art and research perspectives. CIRP Journal of Manufacturing Science and Technology, p. 78-87, 2013.

THOLLANDER, P.; DANESTIG, M.; ROHDIN, P. Energy policies for increased industrial energy efficiency: Evaluation of a local energy programme for manufacturing SMEs. Energy Policy, p. 5774-5783, 2007.

TRIANNI, A. et al. Barriers to industrial energy efficiency in foundries: a European comparison. Journal of Cleaner Production, p. 161-176, 2013.

VENMANS, F. Triggers and barriers to energy efficiency measures in the ceramic, cement and lime sectors. Journal of Cleaner Production, p. 133-142, 2014.

VINCI, L. DA Energia, fontes renováveis e etanol, 2008. Disponível em: < http://www.citador.pt/frases/os-que-se-encantam-com-a-pratica-sem-a-ciencia-sa-leonardoda-vinci-7233>. Acesso em: 29 jul. 2017

WENTEMI APEANING, R.; THOLLANDER, P. Barriers to and driving forces for industrial energy efficiency improvements in African industries - a case study of Ghana's largest industrial area. Journal of Cleaner Production, p. 204-213, 2013. 